Prepared in cooperation with the Minnesota Department of Transportation and the Minnesota Pollution Control Agency

\title{
Techniques for Estimating the Magnitude and Frequency of Peak Flows on Small Streams in Minnesota Based on Data through Water Year 2005
}

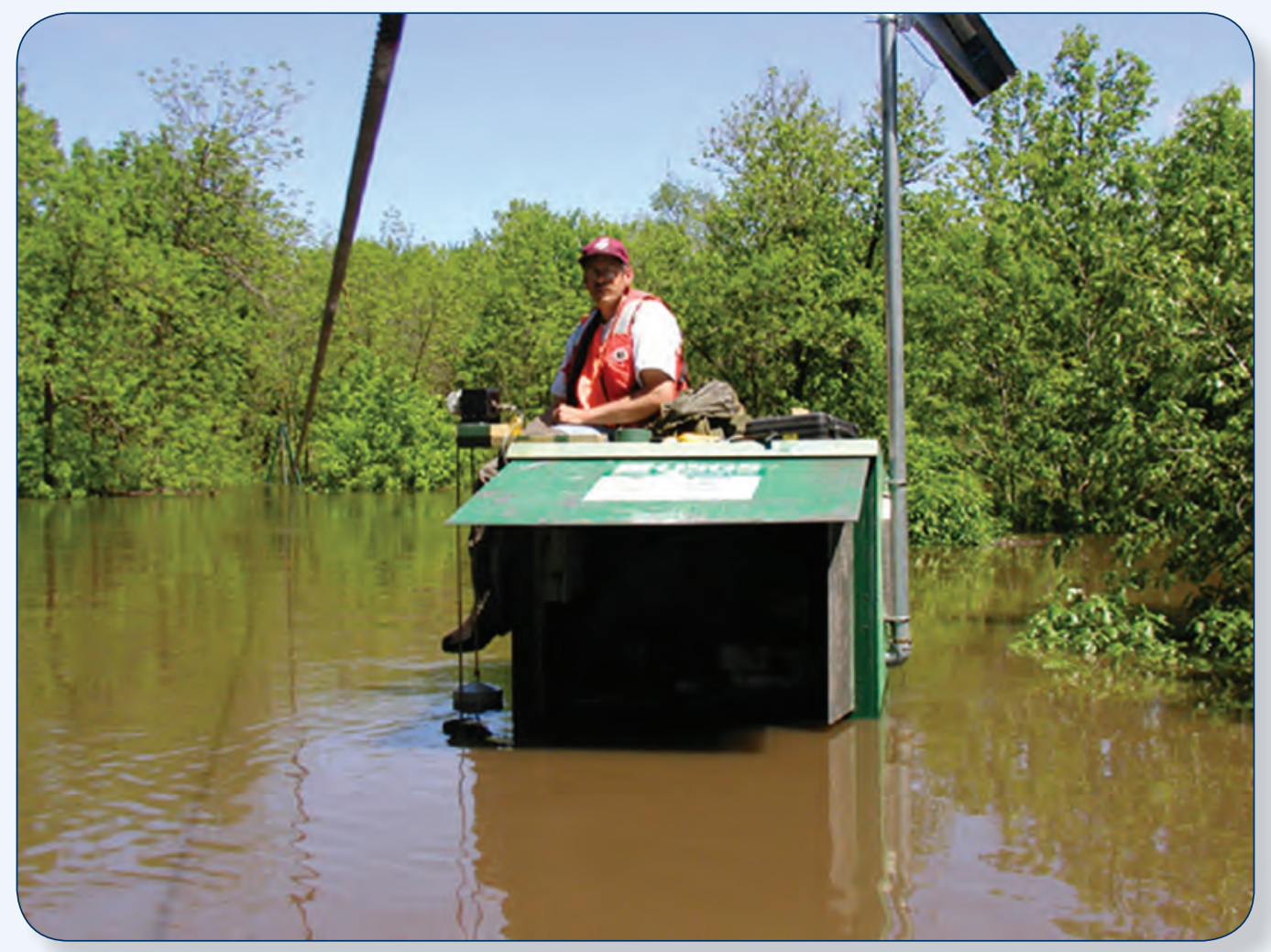

Scientific Investigations Report 2009-5250 
Cover photograph: U.S. Geological Survey streamflow gage 05104500 Roseau River below South Fork near Malung, Minnesota, Flood of June 2002. See U.S. Geological Survey Open File Report http://nd.water.usgs.gov/pubs/ofr/ofrO2278/pdf/ofr02278.pdf(Photo by U.S. Geological Survey). 


\section{Techniques for Estimating the Magnitude and Frequency of Peak Flows on Small Streams in Minnesota Based on Data through Water Year 2005}

By David L. Lorenz, Chris A. Sanocki, and Matthew J. Kocian

Prepared in cooperation with the Minnesota Department of Transportation and the Minnesota Pollution Control Agency

Scientific Investigations Report 2009-5250 


\title{
U.S. Department of the Interior \\ KEN SALAZAR, Secretary \\ U.S. Geological Survey \\ Marcia K. McNutt, Director
}

\section{U.S. Geological Survey, Reston, Virginia: 2010}

\author{
For more information on the USGS — the Federal source for science about the Earth, its natural and living resources, \\ natural hazards, and the environment, visit http://www.usgs.gov or call 1-888-ASK-USGS \\ For an overview of USGS information products, including maps, imagery, and publications, \\ visit http://www.usgs.gov/pubprod \\ To order this and other USGS information products, visit http://store.usgs.gov
}

Any use of trade, product, or firm names is for descriptive purposes only and does not imply endorsement by the U.S. Government.

Although this report is in the public domain, permission must be secured from the individual copyright owners to reproduce any copyrighted materials contained within this report.

Suggested citation:

Lorenz, D.L., Sanocki, C.A., and Kocian, M.J., 2010, Techniques for estimating the magnitude and frequency of peak flows on small streams in Minnesota based on data through water year 2005: U.S. Geological Survey Scientific Investigations Report 2009-5250, 54 p. 


\section{Contents}

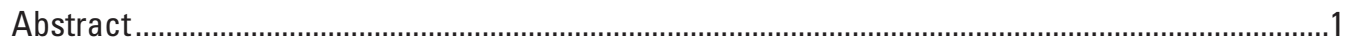

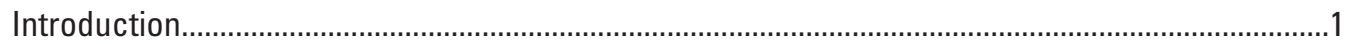

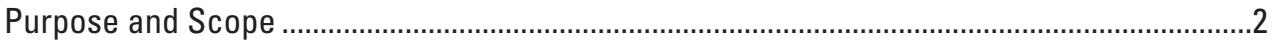

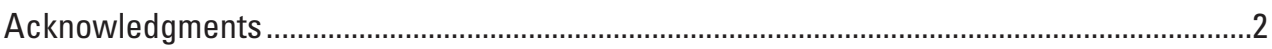

Techniques for Estimating Peak-Flow Frequency .....................................................................

Frequency Analysis of Annual Peak-Flow Data at Selected Gaging Stations ..........................2

Regional Peak-Flow Frequency Methods........................................................................

Estimating Basin Characteristics ..............................................................................

Methods Used to Define Peak-Flow Hydrologic Regions ................................................

Generalized Least Squares Method .............................................................................9

Techniques for Estimating the Magnitude and Frequency of Peak Flows on Small Ungaged

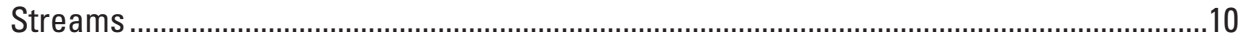

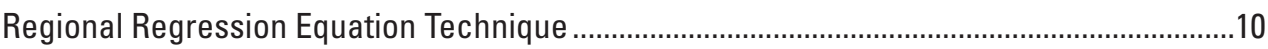

Region of Influence Regression Technique....................................................................11

Comparison Between Regional Regression Equation and Region of Influence Regression

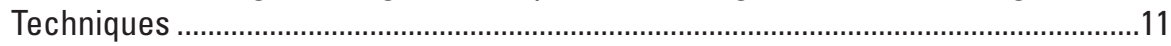

Accuracy and Limitations of the Peak-Flow Estimation Techniques .......................................13

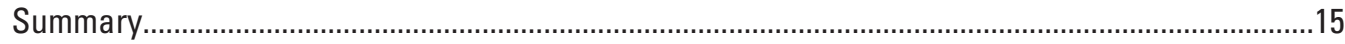

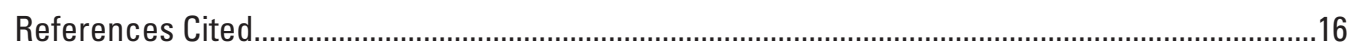

\section{Figures}

1-3. Maps showing:

1. Steamflow-gaging stations for which peak-flow frequency estimates were determined and peak-flow hydrologic regions for Minnesota ....................................3

2. Generalized mean annual runoff in Minnesota for peak-flow estimation ........................6

3. Reclustered hydrologic landscape units for Minnesota..................................................

4-5. Graphs showing:

4. The relation between station cross correlation and geographic distance by relative common area distance for streamflow-gaging stations at $A$ large, $B$ intermediate or mixed, and $C$ small basins

5. Relation between the lapse function and standardized distance for selected values of the decrease rate $(r)$

\section{Tables}

1. Peak-flow frequency estimates for selected streamflow-gaging stations ...........................20

2. Basin characteristics of streamflow-gaging stations used in this report.............................40

3. Streamflow-gaging stations used to estimate generalized mean annual runoff....................48

4. Characteristics of the seven reclustered hydrologic landscape units for Minnesota.............7

5. Regional regression equations, standard errors of the estimate, and the equivalent number

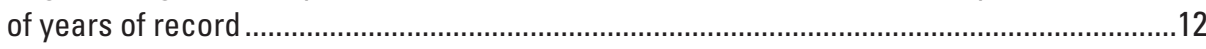

6. Mean prediction error sum of squares (PRESS/n) statistics for selected regions and recurrence intervals.

7. Maximum and minimum values and geometric mean of the basin characteristics used in the regional regression analysis for each region. 


\section{Conversion Factors and Datum}

\begin{tabular}{lcl}
\hline Multiply & By & To obtain \\
\hline & Length & \\
\hline inch (in.) & 2.54 & centimeter $(\mathrm{cm})$ \\
inch (in.) & 25.4 & millimeter $(\mathrm{mm})$ \\
mile (mi) & 1.609 & kilometer $(\mathrm{km})$ \\
\hline & Area & \\
\hline square mile $\left(\mathrm{mi}^{2}\right)$ & 259.0 & hectare $($ ha) \\
square mile $\left(\mathrm{mi}^{2}\right)$ & 2.590 & square kilometer $\left(\mathrm{km}^{2}\right)$ \\
\hline & Flow rate & \\
\hline cubic foot per second $\left(\mathrm{ft}^{3} / \mathrm{s}\right)$ & 0.02832 & cubic meter per second $\left(\mathrm{m}^{3} / \mathrm{s}\right)$ \\
\hline & Slope & \\
\hline feet per mile $(\mathrm{ft} / \mathrm{mi})$ & 0.1894 & meter per kilometer $(\mathrm{m} / \mathrm{km})$ \\
\hline
\end{tabular}

Horizontal coordinate information is referenced to the North American Datum of 1983 (NAD 83).

Water year is the 12-month period, 0ctober 1 through September 30, and is designated by the calendar year in which it ends. Thus, the water year ending September 30, 2005 is called "water year 2005."

\section{Acronyms}

$\begin{array}{ll}\text { DEM } & \text { digital elevation model } \\ \text { EMA } & \text { expected moments algorithm } \\ \text { EY } & \text { equivalent years of record } \\ \text { GIS } & \text { geographic information system } \\ \text { GLS } & \text { generalized least squares } \\ \text { HU } & \text { hydrologic unit } \\ \text { MNDNR } & \text { Minnesota Department of Natural Resources } \\ \text { NED } & \text { National Elevation Dataset } \\ \text { NSS } & \text { National Streamflow Statistics program } \\ \text { NWI } & \text { National Wetlands Inventory } \\ \text { ROI } & \text { region of influence regression } \\ \text { RRE } & \text { regional regression equation } \\ \text { PRESS/n } & \text { mean predication error sum of squares } \\ \text { SEE } & \text { standard errors of the estimate } \\ \text { SEP } & \text { standard error of prediction } \\ \text { STATSGO } & \text { State Soil Geographic } \\ \text { USGS } & \text { U.S. Geological Survey } \\ \text { UTM } & \text { Universal Transverse Mercator } \\ \text { VIF } & \text { variance inflation factor }\end{array}$




\title{
Techniques for Estimating the Magnitude and Frequency of Peak Flows on Small Streams in Minnesota Based on Data through Water Year 2005
}

\author{
By David L. Lorenz, Chris A. Sanocki, and Matthew J. Kocian
}

\section{Abstract}

Knowledge of the peak flow of floods of a given recurrence interval is essential for regulation and planning of water resources and for design of bridges, culverts, and dams along Minnesota's rivers and streams. Statistical techniques are needed to estimate peak flow at ungaged sites because longterm streamflow records are available at relatively few places. Because of the need to have up-to-date peak-flow frequency information in order to estimate peak flows at ungaged sites, the U.S. Geological Survey (USGS) conducted a peak-flow frequency study in cooperation with the Minnesota Department of Transportation and the Minnesota Pollution Control Agency.

Estimates of peak-flow magnitudes for 1.5-, 2-, 5-, 10-, 25-, 50-, 100-, and 500-year recurrence intervals are presented for 330 streamflow-gaging stations in Minnesota and adjacent areas in Iowa and South Dakota based on data through water year 2005. The peak-flow frequency information was subsequently used in regression analyses to develop equations relating peak flows for selected recurrence intervals to various basin and climatic characteristics. Two statistically derived techniques - regional regression equation and region of influence regression - can be used to estimate peak flow on ungaged streams smaller than 3,000 square miles in Minnesota. Regional regression equations were developed for selected recurrence intervals in each of six regions in Minnesota: A (northwestern), B (north central and east central), C (northeastern), D (west central and south central), E (southwestern), and F (southeastern). The regression equations can be used to estimate peak flows at ungaged sites. The region of influence regression technique dynamically selects streamflow-gaging stations with characteristics similar to a site of interest. Thus, the region of influence regression technique allows use of a potentially unique set of gaging stations for estimating peak flow at each site of interest. Two methods of selecting streamflow-gaging stations, similarity and proximity, can be used for the region of influence regression technique.

The regional regression equation technique is the preferred technique as an estimate of peak flow in all six regions for ungaged sites. The region of influence regression technique is not appropriate for regions $\mathrm{C}, \mathrm{E}$, and $\mathrm{F}$ because the interrelations of some characteristics of those regions do not agree with the interrelations throughout the rest of the State. Both the similarity and proximity methods for the region of influence technique can be used in the other regions (A, B, and D) to provide additional estimates of peak flow. The peakflow-frequency estimates and basin characteristics for selected streamflow-gaging stations and regional peak-flow regression equations are included in this report.

\section{Introduction}

Knowledge of the peak flow of floods of a given recurrence interval is essential for regulation and planning of water resources and for design of bridges, culverts, and dams along Minnesota's rivers and streams. Statistical techniques are needed to estimate peak flow at ungaged sites because long-term streamflow records are available at relatively few locations.

For the purpose of estimating peak-flow frequencies, continuous daily streamflow records for streamflow-gaging stations (hereinafter referred to as gaging station) in Minnesota span a relatively short period. The longest record is for the Mississippi River at St. Paul, which is continuous from 1867 to 2005, except for 1871. Gaging of several streams to obtain daily streamflow records was started in about 1909. The number of gaging stations decreased between 1912 and 1920. During the late 1920s and early 1930s, the number of gaging stations increased and many of those stations have been in operation through 2005. Over the years, gaging stations were added where flow information was needed, and other stations were discontinued where additional data were not as critical. Gaging stations operated to obtain daily records generally are located on streams that drain areas greater than 300 square miles $\left(\mathrm{mi}^{2}\right)$ and flow continuously, although in 2008 about 18 percent of daily-record gaging stations in Minnesota had drainage areas of less than $300 \mathrm{mi}^{2}$. 
In the 1950s, planners for the Interstate Highway System learned that little peak-flow information was available for streams smaller than about $60 \mathrm{mi}^{2}$. This information was needed to determine the bridge and culvert sizes to use at road crossings. As a result, small-stream flood investigation studies were initiated nationwide. The program in Minnesota began in 1958 and during the next 6 years about 150 gaging stations were established to determine annual peak flow and stage on streams draining about $60 \mathrm{mi}^{2}$ or less. These peak-flow gaging stations differ from daily-record gaging stations in that streamflow record generally is not continuous - only peak streamflows are recorded. Most of those stations were operated through the 1970s. In the 1980s, gaging for annual peak flow and stage for most of the drainage basins of less than $10 \mathrm{mi}^{2}$ was discontinued. In the past few years, new peak-flow gaging stations were established throughout the State on streams draining areas from $10 \mathrm{mi}^{2}$ to several hundred square miles.

Several previous studies (Prior, 1949; Prior and Hess, 1961; Wiitala, 1965; Patterson and Gamble, 1968; Guetzkow, 1977; Jacques and Lorenz, 1987; Lorenz and others, 1997) have provided peak-flow frequency information at selected gaging stations and presented methods for calculating peakflow frequency data at ungaged sites in Minnesota. Analysis of annual peak-flow records for the first of these reports that used the Log Pearson Type III method of analysis (Guetzkow, 1977) may not have included information about historical floods that occurred before the systematic collection of data and the period of record for many streams was very short from the standpoint of flood history. Gueztzkow (1977) included most of the long-term record stations with low annual peaks from the 1930s drought and high annual peaks during the $1950 \mathrm{~s}$ and 1960s. Historical flood information was incorporated in the analysis done in subsequent reports. Jacques and Lorenz (1987) also used fewer regions than Guetzkow (1977), which resulted in larger standard errors of estimate for the regional equations. Because of the need to have up-to-date peak-flow frequency information in order to estimate peak flows at ungaged sites, the U.S. Geological Survey (USGS) conducted a peak-flow frequency study in cooperation with the Minnesota Department of Transportation and the Minnesota Pollution Control Agency.

\section{Purpose and Scope}

The purpose of this report is to (1) describe the methods and results of the analysis of peak-flow frequency at selected gaging stations in Minnesota and to present the results in adjacent areas in Iowa and South Dakota, and (2) document two statistically derived techniques for estimating peak-flow data at ungaged sites on small unregulated streams in Minnesota. The peak-flow frequency estimates were developed for 330 gaging stations using data through water year 2005. Two techniques - regional regression equation and region of influence regression - for estimating peak-flow data at ungaged sites are described. Because no streams used in this analysis were substantially affected by development, care is needed when applying the results in urban areas.

Gaging stations that have drainage areas greater than $3,000 \mathrm{mi}^{2}$ were not included in this analysis because regulation is prevalent on rivers of that size. River basins affected by regulation include the Red Lake, Minnesota, Mississippi, Rainy, St. Louis, and Red River of the North (Red River). Other gaging stations that were not included in this analysis had peak flows that were affected by controlled storage or regulated releases.

\section{Acknowledgments}

The authors thank David Eash and Joyce Williamson (USGS) for providing basin characteristics and peak-flow analyses of gaging stations in Iowa and South Dakota.

\section{Techniques for Estimating Peak-Flow Frequency}

This section describes the techniques and computations of the analysis of peak-flow frequency at selected gaging stations in Minnesota and adjacent areas in Iowa and South Dakota and the methods and analyses that were required to develop the techniques for estimating peak-flow data on small ungaged streams. This section also presents preliminary computations of basin characteristics required for regression analysis.

\section{Frequency Analysis of Annual Peak-Flow Data at Selected Gaging Stations}

The frequency analysis of annual peak-flow data for selected recurrence intervals (table 1 , at the back of this report) was computed for 330 gaging stations (fig. 1) using data through water year 2005. Peak-flow records for gaging stations in Minnesota are available online at $h t t p: / / n w i s$. waterdata.usgs.gov/mn/nwis/peak. All gaging stations for which peak-flow data were determined had at least 10 years of peak-flow record that could be analyzed. Peak-flow frequency estimates for most gaging stations were determined by fitting a log-Pearson Type III probability distribution to the recorded annual peak flows according to the procedures outlined in Bulletin 17B (Interagency Advisory Committee on Water Data, 1982). The computer program PEAKFQ (Flynn and others, 2006) was used to compute the frequency estimates for those gaging stations. The procedures in Bulletin 17B include tests for unusually high and low peaks, called outliers, that can affect the analysis. Peaks flagged as high outliers require user judgment about putting the outlier into some historical period of record. Peaks flagged as low outliers generally are excluded from the analysis and the conditional probability adjustment described in appendix 5 of Bulletin 17B (Interagency Advisory 


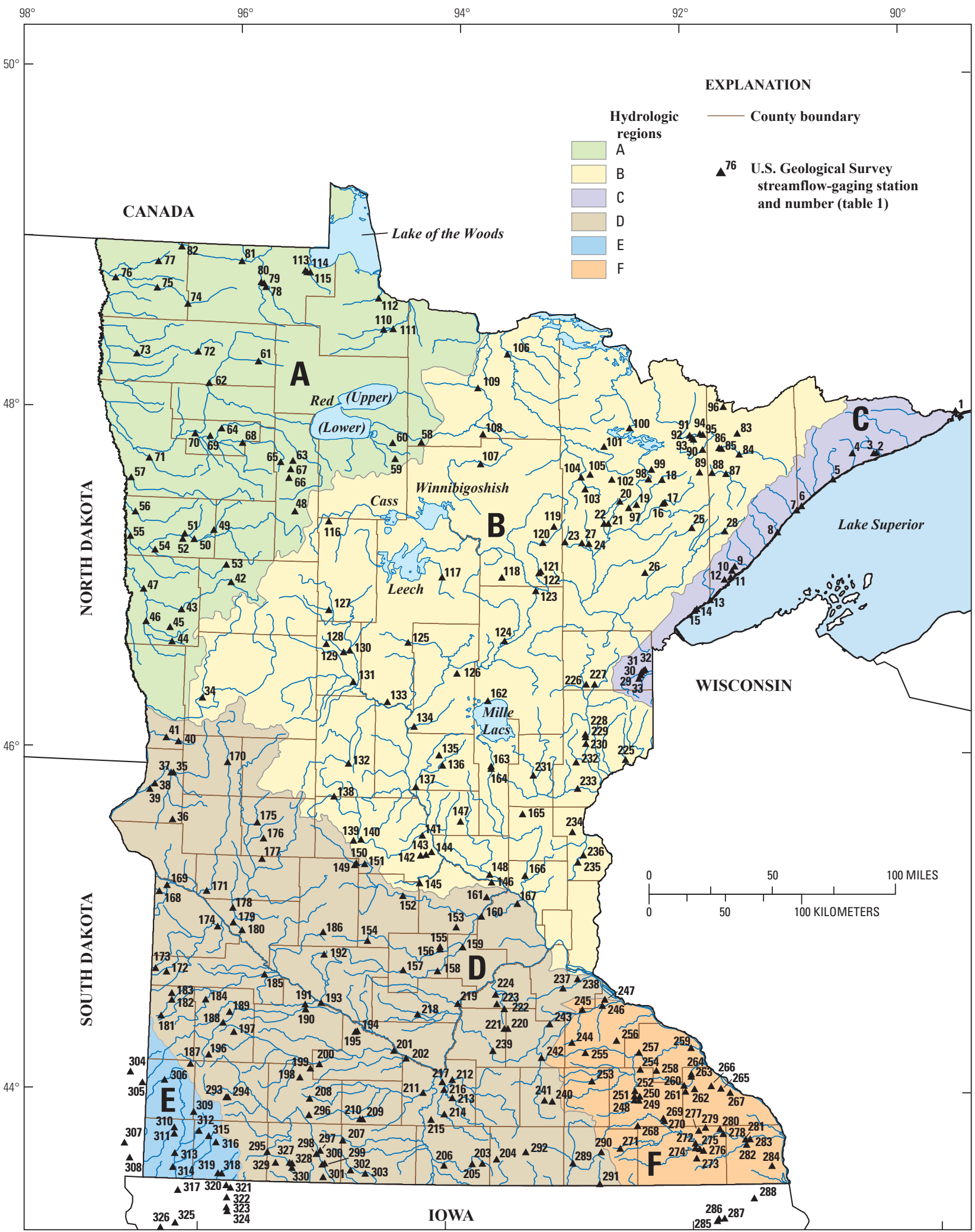

Base from Minnesota Department of Natural Resources, 1993, 1:24,000 and 1:100,000

Universal Transverse Mercator projection, Zone 15

Horizontal coordinate information is referenced to the North American Datum 1983 (NAD 83)

Figure 1. Steamflow-gaging stations for which peak-flow frequency estimates were determined and peak-flow hydrologic regions for Minnesota. 
Committee on Water Data, 1982) is applied to the analysis. Bulletin 17B recommends the use of a skew coefficient that is based on the skew of the log-series of the period of record (commonly termed the "station skew") weighted with a generalized, or regional, skew coefficient. The weighting is based on the length of the period of record and the estimated standard error for the method used to determine the generalized skew coefficient. The generalized skew coefficients for Minnesota gaging stations used in the peak-flow frequency analysis for this report were based on Lorenz (1997).

The approach used in the Log-Pearson Type III analyses for Minnesota gaging stations follows.

1. Where the period of record is continuous or has multiple continuous periods and there is no indication of a historical flood, the record has been treated as though it was a homogeneous systematic record. All gaging stations not listed elsewhere in this section are included in this category. These gaging stations include any where low outliers were flagged and automatically excluded from the analysis.

2. Some historical flood peaks that were estimated from records such as newspaper reports were not included in the Log-Pearson Type III analysis because of uncertainty in magnitude, uncertainty in the correct historical period, and because the estimated magnitudes of the peaks are not unusual based on the systematic peaks. These gaging stations were 05061000, 05078230, 05134200, 05217000, 05313500, 05355200, 05374000, and 05476010 (table 1).

3. Other historical peaks for short-record sites or well-documented peaks within a known period were included in the Log-Pearson Type III analysis. These gaging stations were 05128500, 05278930, 05319500, 05338500, 05345000, and 05379000 (table 1).

4. The relatively short records at gaging stations 05372800 , 05372930, 05372950, and 05383850 (table 1) had systematic peaks that were substantially large outliers. Based on correlation with the nearby long-record gaging station 05372995, those peaks could be placed into an historical context that matched the 55-year record of that gaging station. The peak-flow analyses for the short-record gaging stations were modified to place the large outliers into the 55-year period that matched the longer-record station.

5. Exceptions to the Bulletin 17B procedure were gaging stations $04015250,04021690,05131750,05221020$, 05229450, 05244200, 05272300, 05272950, 05278120, 05305200, 05318195, 05318897, 05384500, 05387030, and 06482933, which had left-censored peak-flow data (peak flows below the minimum flow that could be quantified) and for which an alternate method was used (Cohn and others, 1997). The alternate method, the expected moments algorithm (EMA), was used to reduce bias that results from the methods described in Bulletin 17B. Both methods assume that the peaks have a log-Pearson
Type III distribution, which is characterized by the mean, standard deviation, and skewness of the log-transformed peak-flow values. EMA code for the R statistical package was used (T.A. Cohn, U.S. Geological Survey, written commun., 2006) for these Minnesota gaging stations that had left-censored peak data.

The peak-flow frequency estimates for gaging stations in Iowa and South Dakota were obtained from USGS offices in those states. The peak-flow frequency estimates for stations outside of Minnesota also are included in table 1. The analyses for gaging stations outside of Minnesota were based on the procedures applicable for the respective state (David Eash, U.S. Geological Survey, written commun., 2006, for Iowa; and Joyce Williamson, U.S. Geological Survey, written commun., 2007, for South Dakota). The peak-flow frequency estimates for gaging stations outside of Minnesota were thought to be very similar to the reported values if uniform procedures, using consistent generalized skew coefficient and using EMA for left-censored peaks, had been applied because those modifications result in relatively small adjustments to the frequency analysis of the station record.

\section{Regional Peak-Flow Frequency Methods}

Regional equations expressing peak-flow frequency as a function of various explanatory variables were developed using regression methods. The generalized least squares (GLS) method was used to develop the regression equations within each of six peak-flow hydrologic regions (fig. 1).

\section{Estimating Basin Characteristics}

Seven basin characteristics were used as possible explanatory variables in the regression equations. The selections of basin characteristics for this study were based on the results from previous studies and the availability of soil data since the previous study (Lorenz and others, 1997). Drainage area, main-channel slope, lake area, storage area, and generalized mean annual runoff were all used as explanatory variables in previous studies. The selection of soil hydrologic groups A (high infiltration rate and low runoff potential) and D (very slow infiltration rate and high runoff potential) as basin characteristics was based on recent studies that indicated soil could be an important characteristic in estimating flood peaks (Perry and others, 2004; Soong and others, 2004; Walker and Krug, 2003). All of those studies used soil permeability, but soil hydrologic group was used in this study to avoid interpreting large ranges of soil permeability in the State Soil Geographic (STATSGO) database (U.S. Department of Agriculture, 1991).

Basin characteristics for the 330 gaging stations for which peak-flow data were determined were estimated by compiling applicable datasets, converting to common formats, correcting anomalies, delineating boundaries, and computing values of selected characteristics. Basins for USGS gaging stations were delineated using a geographic information system 
(GIS) to analyze 10-meter digital elevation models (DEMs) derived from 30-meters DEMs (Minnesota Department of Natural Resources (MNDNR), 2009, Data Deli), which had elevations lowered by stream traces to force mapped drainage patterns. Level 6 (12-digit) hydrologic unit (HU) boundaries (Natural Resources Conservation Service and others, 2004) and lakeshed boundaries created by the Minnesota Lake Watershed Delineation Project (Solstad and Vaughn, 2007) were used to aid basin delineation. These boundaries were used to force correct basin boundaries by adding elevation to the DEMs along the boundaries. Several other data sources were used to delineate basins that included areas outside Minnesota. Canadian DEMs were obtained from the online application Geobase (Canadian Council on Geomatics, 2008). These Canadian DEMs had a resolution of 0.75 arc seconds, or approximately 22.5 meters. The USGS National Elevation Dataset (NED) was used for delineating basins in neighboring states. The stream trace data used to force mapped drainage patterns was the "DNR 24K Streams" from the MNDNR (2009) Data Deli. The MNDNR streams layer was modified to ensure correct directionality and checked to ensure that there were no streams crossing Level 6 HUs or MNDNR lakeshed boundaries. Arc Hydro, a geospatial hydrologic data structure and suite of GIS tools for managing water-resources data (Center for Research in Water Resources, 2003), was used to delineate basins and to compute basin characteristics (table 2, at the back of this report).

Basin polygons for the gaging stations were overlaid with each of the characteristics layers, and a value (that is, mean or percent) was computed. Due to Arc Hydro requirements, all characteristics layers were in grid format; characteristics layers that were not in grid format when retrieved from the data source were converted to grid format.

The drainage area, variable name DAREA (table 2), is the area in square miles within the basin for each gaging station. It represents the entire area within the basin and includes any areas that might be considered noncontributing.

The main-channel slope, variable name SLOPE, is defined as the slope of the main channel in feet per mile between the 10th and 85th percentile of the distance between the gaging station and the basin boundary. The Arc Hydro tool identified the main channel based on the $10-\mathrm{m}$ resolution Level 2 DEMs, identified the 10- and 85-percentile points, and extracted the elevation of the two percentile points. The difference in elevation between the points was divided by the main channel stream length between the points to compute the slope in feet per mile.

Lake area, variable name $L A K E$, and storage area, variable name STOR, were computed from National Wetlands Inventory (NWI) data (U.S. Fish and Wildlife Service, 2008). NWI data were extracted for the basin for each gaging station to estimate the percentage of lake and storage area in each basin. Lake area included all NWI polygons classified as 'Lacustrine,' and storage area included all polygons classified as 'Lacustrine' or 'Palustrine.' The percentage for each variable was computed as the total area of all extracted polygons divided by the drainage area, and multiplied by 100 . The variables in the regression equations have a constant of 1 added to them, so a computed value for percent lake area of 0 would be 1 when used in the regression equation.

The soil hydrologic group A, variable name SOILA, and the soil hydrologic group D, variable name SOILD, were computed from STATSGO (U.S. Department of Agriculture, 1991). Soils of hydrologic group A have a high infiltration rate even when thoroughly wetted, and primarily consist of deep, well-drained to excessively drained sands or gravels. Soils of hydrologic group D have an extremely slow infiltration rate when thoroughly wetted and primarily consist of clay soils that have high swelling potentials, soils that have permanent high water tables, soils that have claypan or clay layers at or near the surface, or shallow soils over nearly impervious material. The total area of soils classified as hydrologic group A or D was computed for each STATSGO mapping unit from the component soil information. The percent area for each variable was computed as the total area of all extracted mapping units divided by the drainage area and multiplied by 100 . The variables in the regression equations have a constant of 1 added to them, so a computed value for percent soil hydrologic group A of 0 would be 1 when used in the regression equation.

Generalized mean annual runoff, variable name ROFF, is an estimate of the mean regional streamflow in inches. A map of mean annual runoff was prepared to provide updated, generalized mean annual runoff values for this study by using 261 daily-record gaging stations from Minnesota and the surrounding states of Iowa, North and South Dakota, and Wisconsin (fig. 2, table 3, at the back of this report). These gaging stations include 117 of the 330 peak-gaging stations (table 1) that had at least 10 years of continuous streamflow data between 1940 and 2005. Some additional gaging stations within Minnesota were included in these gaging stations that could not be used for the peak-flow analysis because of some condition, such as regulation, that affects peak flow, but not the mean annual flow. All complete water years from 1940 through 2005 were used in the analysis. This range of dates was selected because most peak-flow records correspond to that period. The loess() function in S-PLUS (Insightful, 2005) was used to create the generalized mean annual runoff grid. The explanatory variables were the easting and northing of the basin centroid in meters of Universal Transverse Mercator (UTM) zone 15. The following were control arguments of the final model for the loess() function: $\operatorname{span}=0.3$, degree $=2$, normalize $=$ FALSE, and family = "gaussian;" the documentation for the loess() function (Insightful, 2005) provides details about the control arguments. The predicted values for the centroids of each basin are reported in the fitted annual runoff column in table 3 . The range of the residuals was from -4.13 to $4.23 \mathrm{in}$., and the residual standard error was $1.29 \mathrm{in}$. The final generalized mean annual runoff contour map for this study is shown in figure 2 . The generalized mean annual runoff values reported in table 2 were computed for the basin polygons, based on the mean of grid cells within the basin (Center for Research in Water Resources, 2003), for each gaging station using the Arc Hydro 


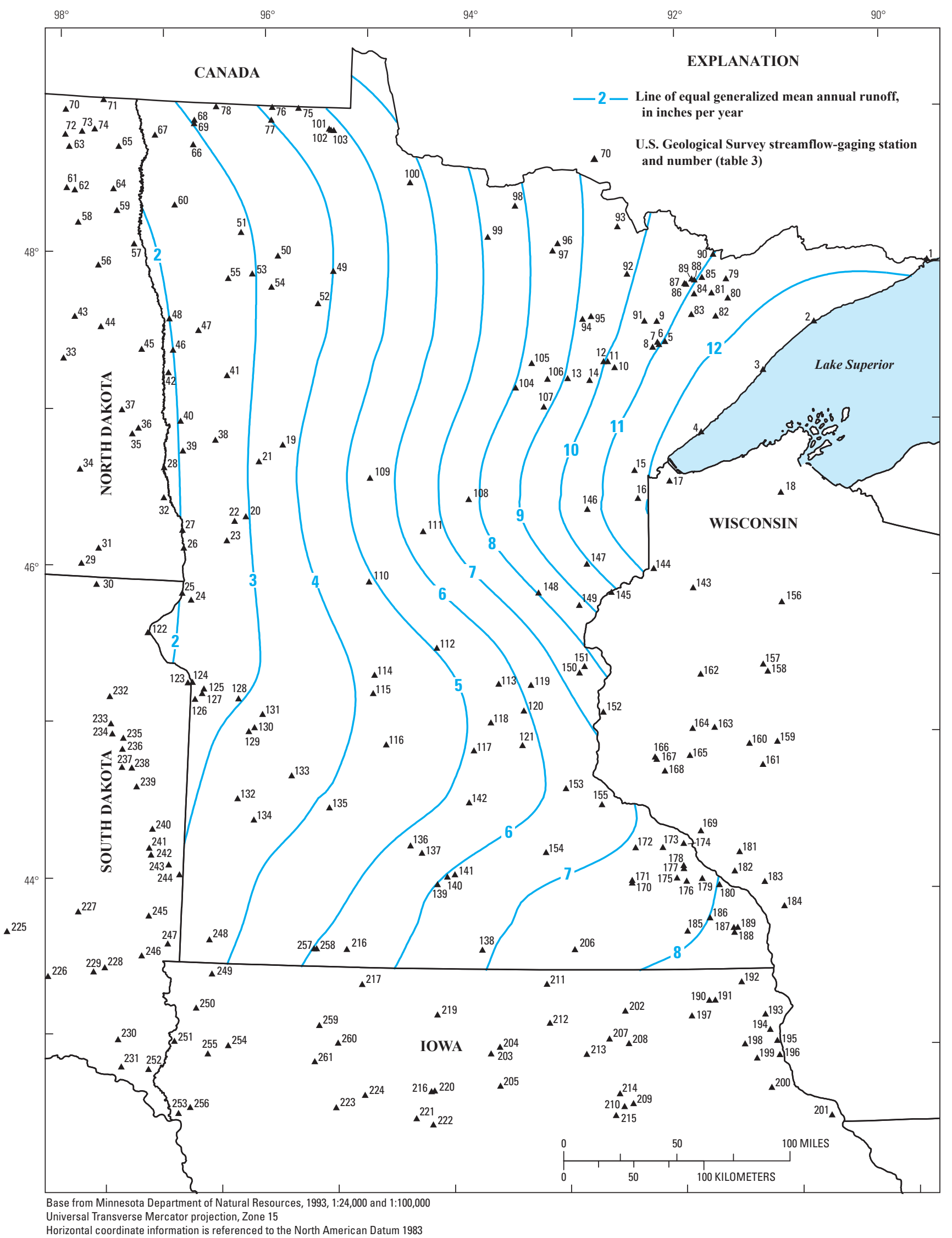

Figure 2. Generalized mean annual runoff in Minnesota for peak-flow estimation. 
GIS extension and are not expected to agree exactly with those reported in table 3 .

\section{Methods Used to Define Peak-Flow Hydrologic Regions}

Previous reports, including Jacques and Lorenz (1987) and Lorenz and others (1997), used an analysis of the pattern of residuals of state-wide regressions to delineate initial peakflow hydrologic regions. Those regression equations included drainage area, main-channel slope, lake area, storage area, and mean annual runoff as explanatory variables. The initial peak-flow hydrologic regions for those reports were refined by residual analysis of the regional regression equations.

To better understand the most important explanatory variables in each region, the concept of hydrologic landscape units (Winter, 2001; Wolock and others, 2004) was used to define initial peak-flow hydrologic regions for this analysis. Those initial peak-flow hydrologic regions were validated and updated based on regional regressions.

Wolock and others (2004) developed a map of the entire United States that showed 20 different hydrologic landscape units. To develop the initial hydrologic regions, data for Minnesota reported in Wolock and others (2004) were extracted and reclustered into seven groups using the k-means algorithm of Hartigan and Wong (1979). That k-means algorithm is an iterative procedure that assigns observations to one of the specified groups to minimize the squared Euclidean distance from the center of the group. Only the variables percent sand, mean slope, percent flatland in upland areas, percent flatland in lowland areas, and precipitation minus potential evapotranspiration were used in the reclustering (Wolock, U.S. Geological Survey, written commun., 2005). Bedrock permeability class was not used in the reclustering because it is not likely to affect surface runoff. The square root of the mean slope was used and the precipitation minus potential evapotranspiration was down-weighted by a factor of 2 for the k-means clustering. The results of the reclustering of the Minnesota data are shown in figure 3 . The characteristics of each of the seven reclustered units are described in table 4.
The initial peak-flow hydrologic regions also are shown on figure 3 . The initial regions were based on a subjective assessment of the association of the seven reclustered groups of hydrologic landscape units and by dividing the regions generally along drainage boundaries. Region A represents one of the most heterogonous regions with low-slope groups 2 and 7 near the Red River, moderately sloped groups 3 and 4 near the drainage boundary, and sandy groups 1 and 5 between those areas. Region B is dominated by sandy groups 1,3 , and 5 with varying slope and flat areas. Regions $\mathrm{C}$ and $\mathrm{F}$ are composed primarily of moderately sloped groups 3 and 4 . Region D is composed of low-slope groups 2 and 7 adjacent to the upper parts of the Minnesota River and moderately sloped group 4 with relatively low sand content in upland areas and the lower part of the Minnesota River. Region E, in southwestern Minnesota, was separated from Region $\mathrm{D}$ although the associations in regions $\mathrm{D}$ and $\mathrm{E}$ appear similar, because the drainage patterns are distinctly different (map 2 in Minnesota Department of Natural Resources, 1997). Region F also shows a drainage pattern different from region D (map 2 in Minnesota Department of Natural Resources, 1997), and likewise was separated from region $\mathrm{D}$.

Regional regression equations were developed for these initial regions, and the residuals were analyzed for consistency - the residuals were required to be approximately normally distributed, homoscedastic (having constant variance throughout the range of fitted values), and show no regional pattern. The only change between the initial (fig. 3) and the final (fig. 1) regions is the change of the relatively high-slope areas in northern Minnesota from initial region $\mathrm{C}$ to final region $\mathrm{B}$. The residuals for the gaging stations in that changed area showed a consistent low bias when included in hydrologic region $\mathrm{C}$, but showed no bias when included in hydrologic region B. No other areas with a distinct bias were noted. The change from the initial regions can be partially explained because the slope characteristics of the entire streams in the final region $\mathrm{C}$ are different from slope characteristics of the entire streams in the high-slope areas in northern Minnesota in final region B and cluster analysis only considers the characteristics of individual small units.

The region for each gaging station used in developing the regional regression equations is listed in table 1 . The regional

Table 4. Characteristics of the seven reclustered hydrologic landscape units for Minnesota.

\begin{tabular}{clccccc}
\hline $\begin{array}{c}\text { Reclustered } \\
\text { group number } \\
\text { (fig.1) }\end{array}$ & \multicolumn{1}{c}{ Description } & $\begin{array}{c}\text { Sand } \\
\text { (percent) }\end{array}$ & $\begin{array}{c}\text { Slope } \\
\text { (feet per mile) }\end{array}$ & $\begin{array}{c}\text { Upland flat } \\
\text { (percent) }\end{array}$ & $\begin{array}{c}\text { Lowland flat } \\
\text { (percent) }\end{array}$ & $\begin{array}{c}\text { Precipitation minus } \\
\text { evapotranspiration } \\
\text { (inches) }\end{array}$ \\
\hline 1 & Sandy/flat upland & 59 & 0.40 & 54 & 29 & 1.80 \\
2 & Low slope/flat lowland & 25 & .37 & 23 & 60 & -.40 \\
3 & Sandy/moderate slope & 64 & 1.23 & 8 & 26 & 4.50 \\
4 & Moderate slope & 31 & 1.17 & 14 & 19 & 3.00 \\
5 & Sandy/flat lowland & 54 & .46 & 11 & 70 & 2.60 \\
6 & High slope & 34 & 2.39 & 2 & 6 & 7.30 \\
7 & Low slope/flat upland & 21 & .50 & 66 & 12 & -1.00 \\
\hline
\end{tabular}




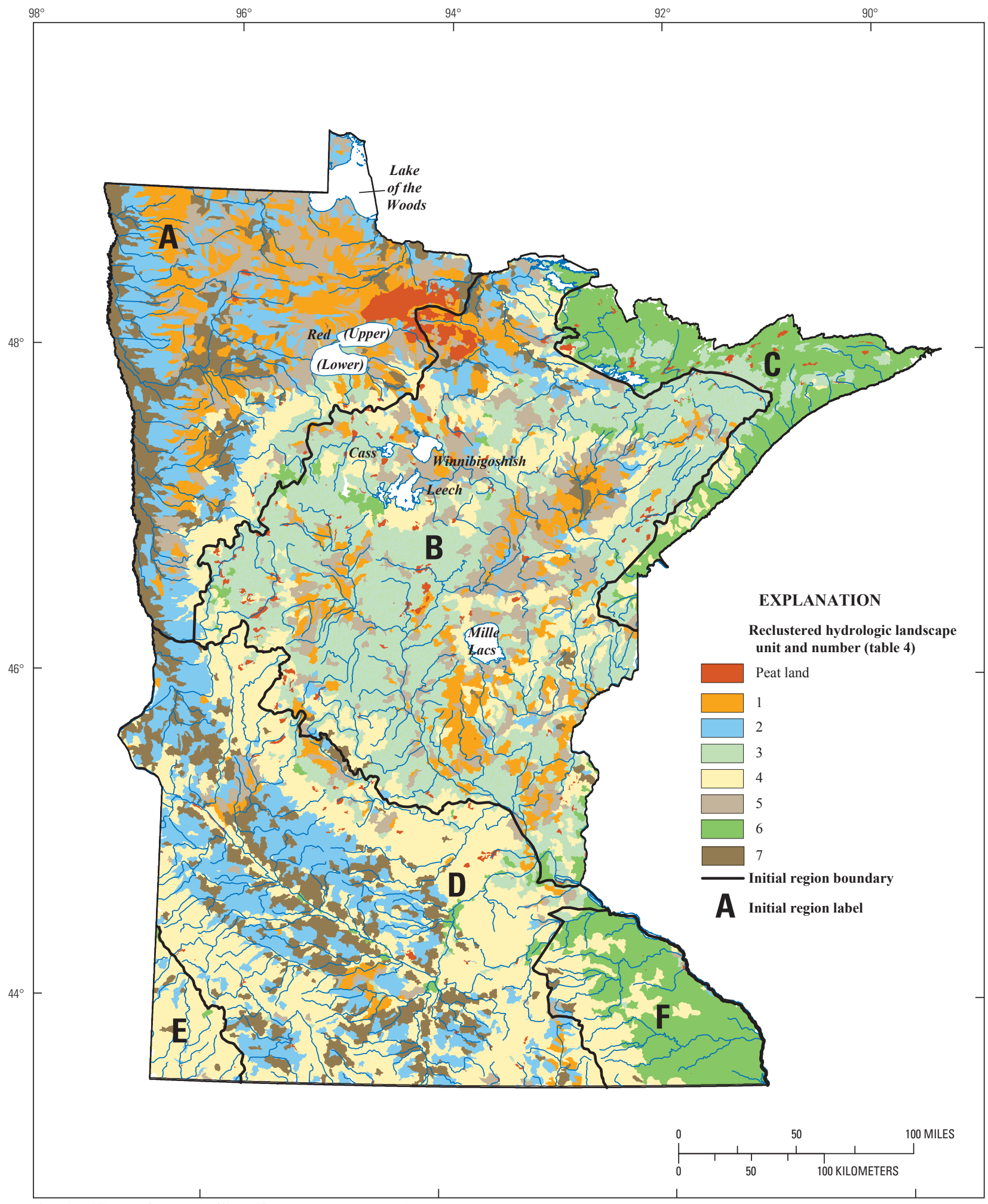

Base from Minnesota Department of Natural Resources, 1993, 1:24,000 and 1:100,000

Universal Transverse Mercator projection, Zone 15

Horizontal coordinate information is referenced to the North American Datum 1983 (NAD 83)

Figure 3 Reclustered hydrologic landscape units for Minnesota. 
boundaries generally follow small drainage divides so that the drainage basin of a small stream will not overlap two regions, making interpretation easier for all small streams.

\section{Generalized Least Squares Method}

Tasker and others (1986) described the use of GLS to estimate the 100-year peak flow for an area in Arizona. They showed that the GLS method provided better estimates than the ordinary least squares method. The GLS method accounts for variance in peak flow frequency estimates at each gaging station because of the difference in record length - the variance decreases with increased record length. The GLS method also accounts for cross-correlated peak-flow data between stations having concurrent record. Cross correlation is the correlation between peak flows at any two gaging stations as a result of similar weather patterns affecting both gaging stations. In ordinary least squares regression, cross-correlated peak-flow data decrease the effective amount of information in an analysis and can contribute to errors in predictive precision (model error) and errors in determination of the coefficients of the explanatory variables (Stedinger and Tasker, 1985).

The GLS method requires a reasonable estimate of the cross correlation between flows at every pair of stations (Tasker and Stedinger, 1989). An estimate based on the measured flows is not reliable because of the short concurrent records usually encountered in peak-flow data. Therefore, sample cross correlations are estimated by relating the distance between each pair of stations to the correlation between peak flows. For this analysis, the "distance" between stations has two components: one is the geographic distance between stations, measured as the distance between stations in miles; the second is related to the relative common area of the two stations. In Minnesota, large basins are more likely to be affected in similar ways by large storms or spring thaws, and small basins are more likely to be affected by local storms that occur within a small area. To express the relative common area as a distance between two stations, a relative distance function is needed. The common area is defined as the square root of the product of the areas of the basins in square miles. The relative common area is expressed as a relative distance by dividing an arbitrary large value by the common area (Equation 1); for this study, the drainage area of the largest basin was chosen as the arbitrary large value.

$$
R C A=\frac{\sqrt{A_{i} * A_{j}}}{A_{m}}
$$

Where

$R C A=$ the relative common area;

$A_{i}$ and $A_{j} \quad=$ the basin areas; and

$A_{m}=$ the arbitrary large area.

The logarithm of that relative distance was used for this study because it linearized the relation between observed cross correlation and the relative common area distance.
The relation between cross correlation and geographic distance conditioned by the relative common area distance is shown in figure 4 . The magnitude of relation between cross correlation and geographic distance, represented by the smooth line in each plot, decreases as the similarity in area decreases - the left plot represents the basins most similar in size (large basins) and the right plot represents those basins least similar (small basins).

A flexible function is needed to describe the decrease in cross correlation as a function of distance. A function was created to calculate the decrease in cross correlation as a function of distance that requires two arguments, the standardized distance, and the rate of decrease.

$$
\rho=1-\frac{\exp \left((1+D / r)^{r}-1\right)-1 /\left(\exp \left((1+D / r)^{r}-1\right)\right.}{\exp \left((1+D / r)^{r}-1\right)+1 /\left(\exp \left((1+D / r)^{r}-1\right)\right.}=\text { lapse }(D, r)
$$

where

$$
\begin{aligned}
\rho & =\text { the estimated cross correlation; } \\
D & =\text { the standardized distance; } \\
r & =\text { the function decrease rate; } \\
\exp () & =\text { the exponentiation function; and } \\
\text { lapse() } & =\text { the name used for the function. }
\end{aligned}
$$

The lapse function decreases for several selected values of the decrease rate (fig. 5).

Stations with at least 30 years of record were selected for the analysis of cross correlation and distance. From stations with at least 30 years of concurrent record, 4,195 pairs of correlations were available. These 4,195 data pairs were used in a nonlinear regression model that related the observed cross correlation to the distance between stations in miles, the relative distance between stations in area, and a rate of decrease. The final function was

$$
\left.C o r_{\text {est }}=0.968 \text { lapse(Dist / } 269+R C A / 8.44,0.805\right)
$$

where

$$
\begin{aligned}
\text { Cor }_{\text {est }} & =\text { the estimated cross correlation; } \\
0.968 & =\text { the intercept term; } \\
\text { lapse } & =\text { the function defined in (2); } \\
\text { Dist } & =\text { the geographic distance between gaging } \\
& \text { stations, in miles; } \\
269= & \text { the coefficient to standardize the } \\
& \text { geographic distance; } \\
R C A= & \text { the relative distance between stations } \\
& \text { defined previously in this section; } \\
8.44= & \text { the coefficient to standardize Area; and } \\
0.805= & \text { the decrease rate. }
\end{aligned}
$$

The lines on figure 5 are estimated values that describe the general relation between cross correlation and geographic distance.

The GLS method was used to develop preliminary equations relating the annual peak flow with a recurrence interval within each of the six hydrologic regions in Minnesota. A 


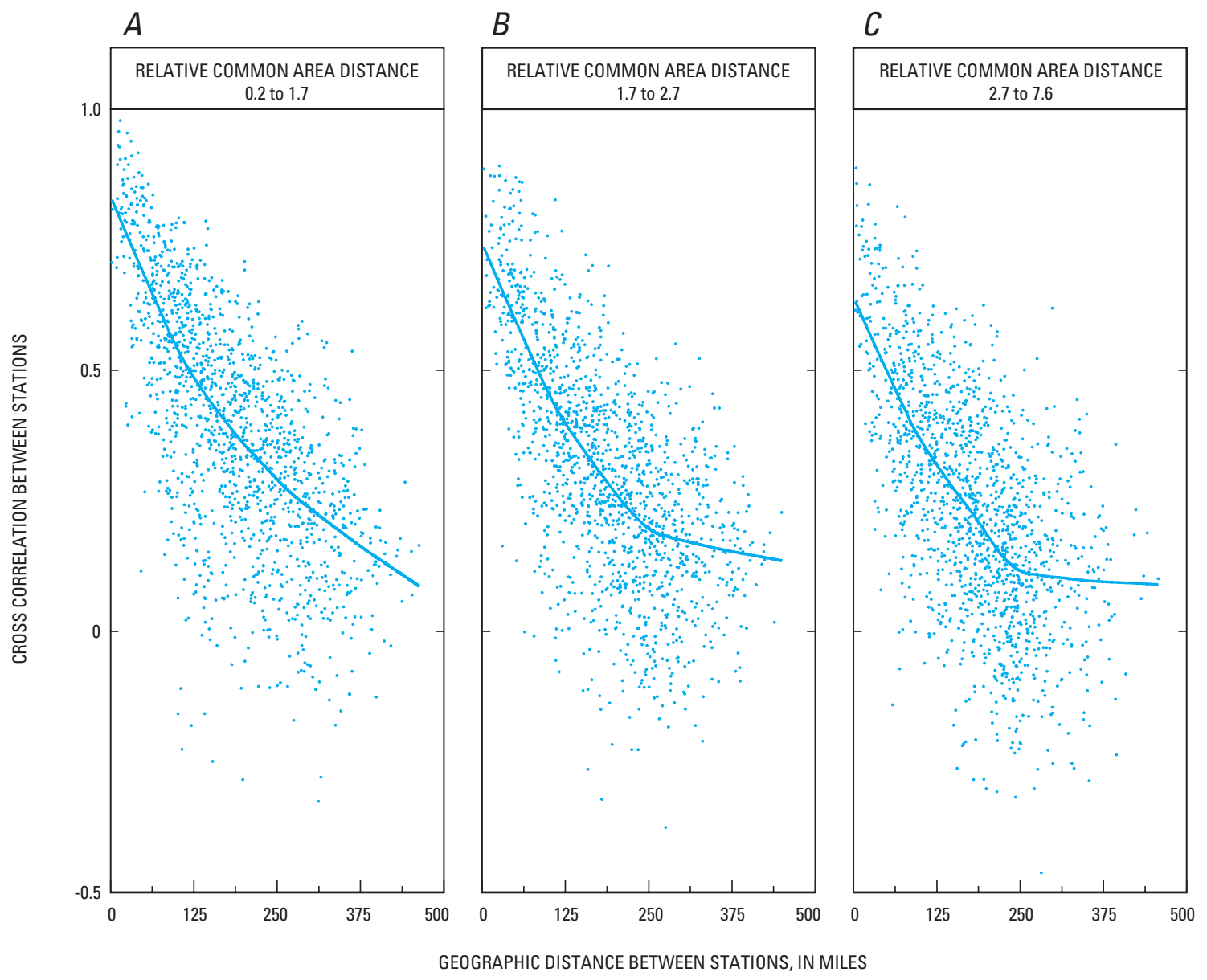

Figure 4. The relation between station cross correlation and geographic distance by relative common area distance for streamflow-gaging stations at $A$ large, $B$ intermediate or mixed, and $C$ small basins.

manual selection of possible combinations of explanatory variables were used in the regression analysis for selected (2-, 25-, and 100-year) recurrence intervals, and the combination producing the minimum mean model error variance and acceptable diagnostic residual plots for linearity, uniformity of variance, and normality was considered the best. To make consistent estimations at the selected recurrence intervals, a consistent set of explanatory variables was used in all of the regression equations. A set of consistent explanatory variables that had logically consistent coefficients and were statistically significant at the 5-percent level was selected for the regression equations for all recurrence intervals within that region.

\section{Techniques for Estimating the Magnitude and Frequency of Peak Flows on Small Ungaged Streams}

This section presents two statistically derived techniques - regional regression equation (RRE) and region of influence regression (ROI) - for estimating peak flows on small, ungaged streams in Minnesota. Both of the techniques relate physical and climatic characteristics to peak flows for 1.5-, 2-, 5-, 10-, 25-, 50-, 100-, and 500-year recurrence intervals. This section also describes the comparison between the two techniques and describes the accuracy and limitations of the techniques.

\section{Regional Regression Equation Technique}

As previously described, the GLS method was used to develop regression equations for each recurrence interval and for each region shown on figure 1. Regression equations, the standard errors of the estimate (SEE), and the equivalent years of record (EY) are described in a following section "Accuracy and Limitations of the Estimating Techniques" and are listed in table 5. The SEE values are included for comparison to previous RRE. The basin characteristics storage area (STOR) and soil hydrologic group D (SOILD) were not significant explanatory variables in the regression equations for any of the six regions.

The National Streamflow Statistics (NSS) Program, available online at $h t t p: / /$ water.usgs.gov/software/nss.html, provides 


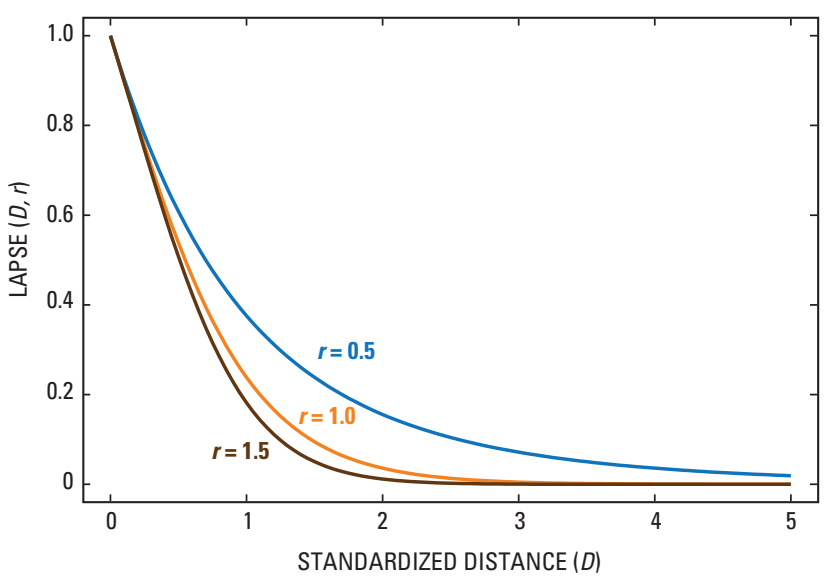

Figure 5. Relation between the lapse function and standardized distance for selected values of the decrease rate $(r)$.

a tool for estimating the magnitude and frequency of flood characteristics for ungaged sites in Minnesota, the other states, the Commonwealth of Puerto Rico, and American Samoa. Using NSS reduces the possibility of computational errors associated with manual computation. The basin characteristics described in this report and used in NSS can be obtained from topographic maps, or digital map data derived from various sources. The USGS has developed a Web application named StreamStats (http://streamstats.usgs.gov/) that automates the process of computing streamflow statistics for ungaged sites and provides previously computed streamflow statistics for USGS gaging stations. StreamStats provides a map-based user interface that appears in a Web-browser window. Users can obtain estimates of streamflow statistics for ungaged sites by clicking on site locations in the interface. A GIS program determines boundaries of the drainage basins for the ungaged sites, measures the physical characteristics of the drainage basins, and inserts the characteristics into the NSS program to solve the regression equations in table 5 that estimate the streamflow statistics for the sites. This process for measuring the basin characteristics is faster, more accurate, and more consistent than previous manual methods. Users also can obtain previously published streamflow statistics and other information for USGS gaging stations by clicking on station locations in the user interface.

\section{Region of Influence Regression Technique}

The fundamental premise of the ROI technique is that there is no need for distinct boundaries between regions (Burn, 1990). The ROI technique defines a new set of regression equations for each ungaged site by selecting gaging stations with characteristics that are similar to that ungaged site. Thus, the ROI technique allows use of a potentially unique set of gaging stations for each site of interest. Two methods are available for this technique. The similarity method selects gaging stations that have similar characteristics (variables).
The proximity method selects gaging stations that are nearby. Predictions obtained by use of the ROI technique generally are closer to the center of the data used to develop the equation than predictions obtained by use of more traditional regression methods. Thus, extrapolation and other errors resulting from assumption of linearity are reduced (Ensminger, 1998). Because ROI computations are mathematically complex, computer programs are necessary to solve the equations. NSS contains the algorithms needed to perform the ROI procedure for states where the ROI method was developed.

\section{Comparison Between Regional Regression Equation and Region of Influence Regression Techniques}

One method for comparing the RRE technique to the ROI technique is to use the PRESS/n statistic, which is the mean prediction error sum of squares. The PRESS/n statistic is determined by removing each station (of $n$ sites) from the analysis, re-developing the regression equations, and comparing the re-estimated peak-flow value to the previously determined value for that station in a region. The differences between the re-estimated and previously determined values are squared and the mean for all stations is computed. That way, $n$ analyses are made without the estimated station being included. It is a reasonably unbiased comparison if the stations are not highly cross correlated.

A listing of the PRESS/n statistics for regions $\mathrm{A}, \mathrm{B}$, and $\mathrm{D}$ for the 2-, 25-, and 100-year recurrence intervals are in table 6. Regions $\mathrm{C}, \mathrm{E}$, and $\mathrm{F}$ were excluded from the analysis because the interrelations among some characteristics of these regions are different from those for the rest of the state. For example, regions $\mathrm{C}$ and $\mathrm{F}$ have larger slope-to-drainage-area ratios than other regions in the state. The 2-, 25-, and 100-year recurrence intervals were selected as representative of the range of all eight recurrence intervals. The minimum PRESS $/ n$ statistics indicate the preferred technique for each region.

The regional regression equation technique appears preferable for all regions. Only the PRESS/n statistic for the ROI proximity method for the 2-year recurrence interval in region $\mathrm{D}$ is less than the corresponding PRESS/n statistic for the RRE technique. However, the PRESS/n statistics for the 25- and 100-year recurrence intervals in region $\mathrm{D}$ are much larger for the proximity ROI technique than for the RRE technique. Therefore, the preferred technique for all regions is RRE. The ROI techniques may be useful for reviewing the value obtained by using the RRE technique, or to provide a second or third estimate of peak flow. The smaller values for the PRESS/n statistics for the regional RRE technique than for either method in the ROI technique indicate that the regions are relatively homogenous and that using hydrologic landscape units and possibly other drainage characteristics is a useful technique to define regions. 
Table 5. Regional regression equations, standard errors of the estimate, and the equivalent number of years of record.

[PK, peak flow for recurrence interval; DAREA, drainage area; SLOPE, main-channel slope; LAKE, lake area; SOILA, soil hydrologic group A; ROFF, generalized mean annual runoff; log, common logarithm; regions are shown in figure 1]

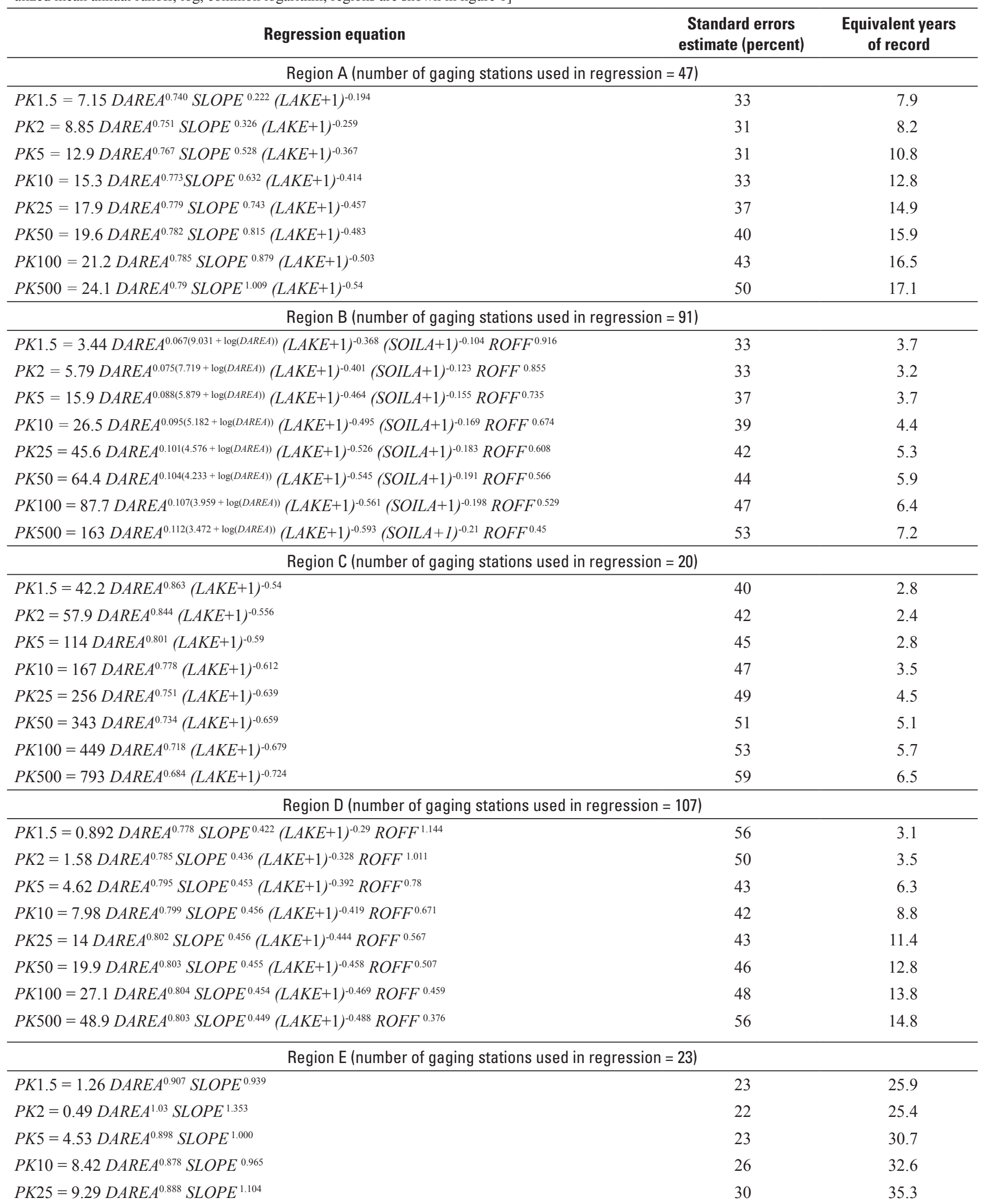


Table 5. Regional regression equations, standard errors of the estimate, and the equivalent number of years of record.-Continued [PK, peak flow for recurrence interval; DAREA, drainage area; SLOPE, main-channel slope; LAKE, lake area; SOILA, soil hydrologic group A; ROFF, generalized mean annual runoff; log, common logarithm; regions are shown in figure 1]

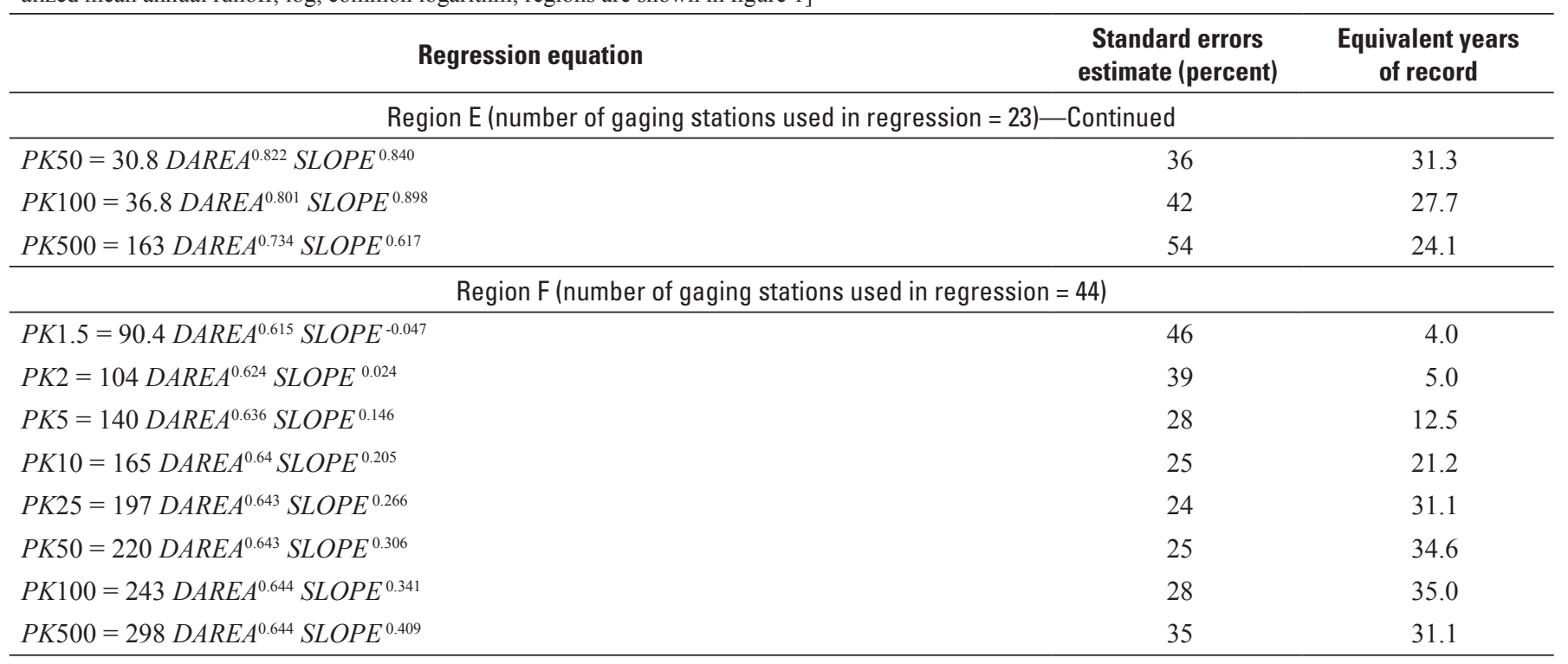

\section{Accuracy and Limitations of the Peak-Flow Estimation Techniques}

The accuracy of a statistically derived equation is measured by the closeness of the estimated value to the true value. Regression analyses give an unbiased estimate of the true value and statistics to assess the accuracy of the estimate.

The SEE, also called residual standard error, is a measure of the fit of the observed data about the regression surface (Riggs, 1968). The SEE is expressed as a percentage of the estimated value. It has traditionally been used for comparing the relative accuracy of the equations, although it is less useful for GLS regressions.
The standard error of prediction (SEP) is an estimate of the accuracy of the result of applying a regression equation to a set of explanatory variables. It accounts for the regression error and the uncertainty of the coefficients of the explanatory variables (Riggs, 1968). It varies from site to site because it is a function of the basin characteristics at a site.

Hardison (1971) presented an equation that defines the EY represented by the regression equation. The EY is the ratio of the mean variance of the logarithms of the annual peak flow to the mean square error of prediction, multiplied by a factor dependent on the recurrence interval. It is an estimate of the number of years of record that would be needed at a site to compute a peak flow at that recurrence interval with the same confidence interval.

Table 6. Mean prediction error sum of squares (PRESS/n) statistics for selected regions and recurrence intervals.

\begin{tabular}{cccc}
\hline $\begin{array}{c}\text { Recurrence interval } \\
\text { (years) }\end{array}$ & $\begin{array}{c}\text { Regional regression } \\
\text { equations }\end{array}$ & $\begin{array}{c}\text { Similarity region of } \\
\text { influence }\end{array}$ & $\begin{array}{c}\text { Proximity region of } \\
\text { influence }\end{array}$ \\
\hline \multicolumn{5}{c}{ Region A } & \\
\hline 2 & 0.02734 & 0.03048 & 0.03512 \\
25 & .03954 & .04793 & .05593 \\
100 & .05341 & .06596 & .07090 \\
\hline \multicolumn{5}{c}{ Region B } \\
\hline 2 & .02533 & .03152 & .03307 \\
100 & .04261 & .05516 & .06111 \\
\hline \multicolumn{5}{c}{} & Region D & .07828 \\
\hline 2 & .05429 & .07088 & .05015 \\
25 & .05173 & .06435 & .05588 \\
100 & .05021 & .05740 & .07674 \\
\hline
\end{tabular}


Table 7. Maximum and minimum values and geometric mean of the basin characteristics used in the regional regression analysis for each region.

$\left[\mathrm{mi}^{2}\right.$, square miles; $\mathrm{ft} / \mathrm{mi}$, feet per mile; in/yr, inches per year]

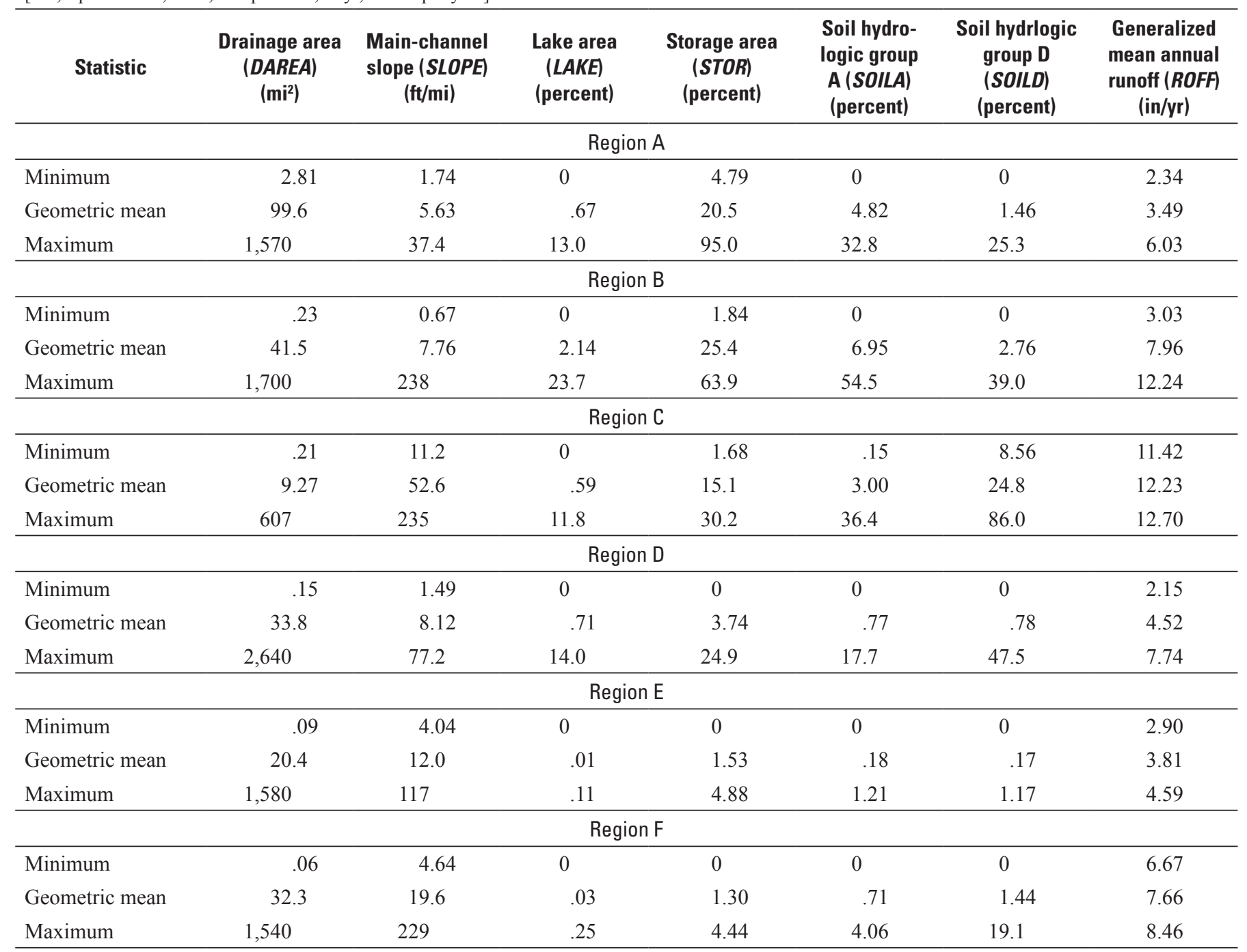

The 90-percent prediction interval is another measure of the uncertainty of the estimated value. It is the estimated value multiplied or divided by a factor that is dependent on the mean SEP and the critical value of the t-distribution for a particular model. The information necessary to compute prediction intervals are included in the equations for Minnesota in the NSS (U.S. Geological Survey, 2009).

The accuracy of the estimating equation is limited by the uncertainty of the input data. Uncertainty has two components: variance, a measure of the random variation about the true value, and bias, the consistent deviation of the value from the true value. How well the peak-flow estimates from the log-Pearson Type III analysis of the recorded annual peak flows predicts the actual population of peak flows depends on the sample size, the accuracy of each recorded peak value, and how well the log-Pearson Type III distribution fits the actual distribution (Interagency Advisory Committee on Water Data, 1982).

The accuracy of the regression estimate is affected by errors in the explanatory variables. Errors in quantifying the drainage-basin characteristics result from an inability to completely describe the effect of those characteristics. For example, the effects of wetlands and lakes depend on their size and location in the basin and in the stream channels, but the explanatory variable storage is simply expressed as a percentage of total drainage area without regard to size or location.

Bias of an estimate can result from systematic errors in the computation of the response variable. Bias in the computation of the response variable probably is the result of collecting peak-flow data over a period that does not reflect the long-term population of peak flows. Most short-term records at gaging stations used in this analysis were from water years 1960 through 1985 and recent (through water year 2005) 
periods. The derived peak-flow statistics reflect those periods, which may not be representative of the long-term conditions.

The accuracy of an estimate made using the techniques presented in this report also can be affected by the user. Each user will make certain decisions based on their best judgment about the actual outline of the drainage basin, the path of the main channel, interpolation of generalized runoff, and the source of lake and wetland data. These individual sources of error can be reduced by use of shared computer datasets that are updated as improved information becomes available and the use of a GIS that provides consistent results.

The accuracy of peak-flow estimates made at sites immediately downstream from a lake or ponded area where the storage capacity could substantially alter peak-flow characteristics can be improved by a routing adjustment. In such places, the frequency relations could be used as an aid in developing a hydrograph of the inflow and then a simulation of that flow can be routed through the lake to determine the peak of the outflow.

The values of the explanatory variables used in this analysis were all computed from consistent datasets using a GIS or spatial interpolation software. Careful analysis using 71/2-minute USGS topographic maps should provide accurate estimates of drainage area, main-channel slope, percent storage, and percent lake. Interpolation of generalized runoff from figure 2 can be improved by using Fitted Annual Runoff data from table 3 in conjunction with data from nearby gaging stations.

Multi-collinearity among the explanatory variables can have adverse effects on the accuracy of coefficients of those variables in the regression equation (Helsel and Hirsch, 1992). Freund and Minton (1979) indicated that estimations from regressions where the explanatory variables exhibit multicollinearity are reliable when the correlation structure of the estimated site is similar to that of the data used to construct the regression equation. This condition likely is true for any site in Minnesota using any of the techniques for estimating peak flow described herein.

Collinearity can be intrinsic in the data, such as the relation between main-channel slope and drainage area, or introduced in the computation of variables, such as percent lake area and percent storage area. The correlation (a measure of collinearity) between slope and drainage area is about -0.77 in Minnesota. The correlation between percent storage and percent lake is less than 0.54 for regions in Minnesota. A measure of multi-collinearity is the variance inflation factor (VIF). Helsel and Hirsch (1992) stated that VIFs of less than 10 were not a concern in multiple linear regression analyses. The VIF for each explanatory variable in each RRE in this study was less than 10.

Peak-flow frequency regression equations presented in this report can be used to estimate the peak flows of several recurrence intervals on most small ungaged streams in Minnesota. The applicability and accuracy of these relations depend partly on whether the basin characteristics of the site are within the range of the characteristics used to define the peak-flow regression equations. The range in sampled basin characteristics is large enough to allow the application of the equations at most sites where streamflow is not affected by regulation, diversion, or urbanization. The minimum, geometric mean (corrected for offsets, if necessary), and maximum values for each basin characteristic for each region are listed in table 7.

The geometric mean is included in table 7 because it represents the central value of the data better than the arithmetic mean. Where runoff is included as an explanatory variable, the range of those data is sufficient to ensure that any value in that region is within the range. The NSS program (U.S. Geological Survey, 2009) will issue a warning message if the estimated peak flow is an extrapolation beyond the data on which the estimation is based.

\section{Summary}

Knowledge of the peak flow of floods of a given recurrence interval is essential for regulation and planning of water resources and for design of bridges, culverts, and dams along Minnesota's rivers and streams. Statistical techniques are needed to estimate peak flow at ungaged sites because longterm streamflow records are available at relatively few places. Because of the need to have up-to-date peak-flow frequency information in order to estimate peak flows at ungaged sites, the U.S. Geological Survey (USGS) conducted a peak-flow frequency study in cooperation with the Minnesota Department of Transportation and the Minnesota Pollution Control Agency.

Estimates of peak-flow magnitudes for 1.5-, 2-, 5-, 10-, 25-, 50-, 100-, and 500-year recurrence intervals are presented for 330 streamflow-gaging stations in Minnesota and adjacent areas in Iowa and South Dakota based on data through water year 2005. The peak-flow frequency information was subsequently used in regression analyses to develop equations relating peak flows for selected recurrence intervals to various basin and climatic characteristics.

Two statistically derived techniques-regional regression equation and region of influence regression - can be used to estimate peak flow on small, ungaged streams in Minnesota. Regional regression equations were developed for each recurrence interval in each of the six regions in Minnesota: A (northwestern), B (north central and east central), C (northeastern), D (west central and south central), E (southwestern), and $\mathrm{F}$ (southeastern). The regression equations can be used to estimate peak flows at ungaged sites. The region of influence regression technique dynamically selects gaging stations with characteristics similar to a site of interest. Two methods of selecting gaging stations, similarity and proximity, can be used in the region of influence regression technique. Thus, the region of influence regression technique allows use of a potentially unique set of gaging stations for estimating peak flow at each site of interest. 
The regional regression equation technique is the preferred technique as a first estimate of peak flow in all six regions for ungaged sites. The region of influence regression technique is not appropriate for regions $\mathrm{C}, \mathrm{E}$, and $\mathrm{F}$ because the interrelations of some characteristics of those regions do not agree with the interrelations throughout the rest of the State. Both the similarity and proximity methods for the region of influence technique can be used in the other regions (A, B, and $\mathrm{D}$ ) to review the value obtained by the regional regression equation, or to provide a second or third estimate of peak flow. Tables showing the peak-flow-frequency estimates and basin characteristics for selected streamflow-gaging stations, and regional peak-flow regression equations, are presented. Discussions of the accuracy and limitations are also included.

\section{References Cited}

Burn, D.H., 1990, Evaluation of regional flood frequency analysis with a region of influence approach: Water Resources Research, v. 26, no. 10, p. 149-165.

Canadian Council on Geomatics, 2008, GeoBase, accessed February 2009, at URL http://www.geobase.ca/geobase/en/.

Center for Research in Water Resources, 2003, Arc Hydro Online Support System, accessed August 2008, at URL http://www.crwr.utexas.edu/giswr/hydro/ArcHOSS/index. cfm.

Cohn, T.A., Lane, W.L., and Baier, W.G., 1997, An algorithm for computing moments-based flood quantile estimates when historical flood information is available: Water Resources Research, v. 33, no. 9, p. 2,089-2,096.

Ensminger, P.A., 1998, Floods in Louisiana, magnitude and frequency: Baton Rouge, Louisiana Department of Transportation and Development Water Resources Technical Report no. 60, 333 p.

Flynn, K.M., Kirby, W.H., Mason, R., and Cohn, T.A., 2006, Estimating magnitude and frequency of floods using the PeakFQ program: U.S. Geological Survey Fact Sheet 2006-3143, 1 sheet.

Freund, R.J., and Minton, P.D., 1979, Regression methods, a tool for data analysis: New York, Marcel Dekker, Inc., 261 p.

Guetzkow, L.C., 1977, Techniques for estimating magnitude and frequency of floods in Minnesota: U.S. Geological Survey Water-Resources Investigations Report 77-31, 33 p.

Hardison, C.H., 1971, Prediction of error of regression estimates of streamflow characteristics at gaged sites: U.S. Geological Survey Professional Paper 750-C, p. C228C236.
Hartigan, J.A. and Wong, M.A., 1979, A k-means clustering algorithm: Applied Statistics, v. 28, p. 100-108.

Helsel, D.R., and Hirsch, R.M., 1992, Statistical methods in water resources: Amsterdam, The Netherlands, Elsevier, $522 \mathrm{p}$.

Insightful, 2005, S-PLUS 7 for Windows User's Guide: Seattle, Wash., 664 p.

Interagency Advisory Committee on Water Data, 1982, Guidelines for determining flood-flow frequency: Bulletin 17B of the Hydrology Subcommittee, Office of Water Data Coordination, U.S. Geological Survey, 183 p.

Jacques, J.E., and Lorenz, D.L., 1987, Techniques for estimating the magnitude and frequency of floods in Minnesota: U.S. Geological Survey Water-Resources Investigations Report 87-4170, 48 p.

Lorenz, D.L., 1997, Generalized skew coefficients for floodfrequency analysis in Minnesota: U.S. Geological Survey Open-File Report 97-4089, 15 p.

Lorenz, D.L., Carlson, G.H., and Sanocki, C.A., 1997, Techniques for estimating peak flow on small streams in Minnesota: U.S. Geological Survey Water-Resources Investigations Report 97-4249, 44 p.

Minnesota Department of Natural Resources, 1997, Minnesota wetlands and surface water resources: St. Paul, Minnesota Department of Natural Resources, 1 plate.

Minnesota Department of Natural Resources, 2009, Data Deli, accessed February 2009, at URL http://deli.dnr.state.mn.us.

Natural Resources Conservation Service, U. S. Geological Survey, and U.S. Environmental Protection Agency, 2004 Federal standards for delineation of hydrologic unit boundaries: Version 2.0, $60 \mathrm{p}$.

Patterson, J.L., and Gambel, G.R., 1968, Magnitude and frequency of floods in the United States, Part 5: U.S. Geological Survey Water-Supply Paper 1678, 546 p.

Perry, C.A., Wolock, D.M., and Artman, J.C., 2004, Estimates of flow duration, mean flow, and peak-discharge frequency values for Kansas Stream locations: U.S. Geological Survey Scientific Investigations Report 2004-5033, 651 p.

Prior, C.H., 1949, Magnitude and frequency of floods in Minnesota: St. Paul, Minnesota Department of Conservation, Division of Waters Bulletin 1, 128 p.

Prior, C.H., and Hess, J.H., 1961, Floods in Minnesota-Magnitude and frequency: St. Paul, Minnesota Department of Conservation, Division of Waters Bulletin 12, 142 p.

Riggs, H.C., 1968, Some statistical tools in hydrology: U.S. Geological Survey Techniques of Water-Resources Investigations book 4, chapter A1, $39 \mathrm{p}$. 
Solstad, J., and Vaughn, S., 2007, The Minnesota Lake Watershed Delineation (Lakeshed) Project: Minnesota Department of Natural Resources, accessed on August 2007, at URL http://www.dnr.state.mn.us/watersheds/lakeshed_project.html.

Soong, D.T., Ishii, A.L., Sharpe, J.B., and Avery, C.F., 2004, Estimating flood-peak discharge magnitudes and frequencies for rural streams in Illinois: U.S. Geological Survey Scientific Investigations Report 2004-5103, 158 p.

Stedinger, J.D., and Tasker, G.D., 1985, Regional hydrologic analysis 1 - Ordinary, weighted, and generalized least squares compared: Water Resources Research, v. 21, no. 9, p. $1,421-1,432$.

Tasker, G.D., Eychaner, J.H., and Stedinger, J.R., 1986, Application of generalized least squares in hydrologic regression analysis, in Selected papers in the hydrologic sciences: U.S. Geological Survey Water-Supply Paper 2310, p. 107-115.

Tasker, G.D., and Stedinger, J.D., 1989, An operational GLS model for hydrologic regression: Journal of Hydrology, v. 111, p. 361-375.

U.S. Department of Agriculture, 1991, State soil geographic (STATSGO) data base: Natural Resources Conservation Service Miscellaneous Publication Number 1492, unpaged, accessed March 2009 as STATSGO2 at URL http://soildatamart.nrcs.usda.gov.
U.S. Fish and Wildlife Service, 2008, National Wetlands Inventory: Washington, D.C., U.S. Department of the Interior, Fish and Wildlife Service, accessed November 2008, at URL http://www.fws.gov/nwi/.

U.S. Geological Survey, 2009, National streamflow statistics program: last accessed on March 12, 2009, at http://water. usgs.gov/software/NSS/.

Walker, J.F., and Krug, W.R., 2003, Flood-frequency characteristics of Wisconsin streams: U.S. Geological Survey Water-Resources Investigations Report 03-4250, 42 p., 2 plates.

Wiitala, S.W., 1965, Magnitude and frequency of floods in the United States, Part 4: U.S. Geological Survey Water-Supply Paper 1677, $357 \mathrm{p}$.

Winter, T.C., 2001, The concept of hydrologic landscapes: Journal of the American Water Resources Association, v. 37, p. 335-349.

Wolock, D.M., Winter, T.C., and McMahon, G., 2004, Delineation and evaluation of hydrologic-landscape regions in the United States using geographic information system tools and multivariate statistical analyses: Environmental Management, v. 34, supplement 1, p. S71-S88. 

Tables 1-3 


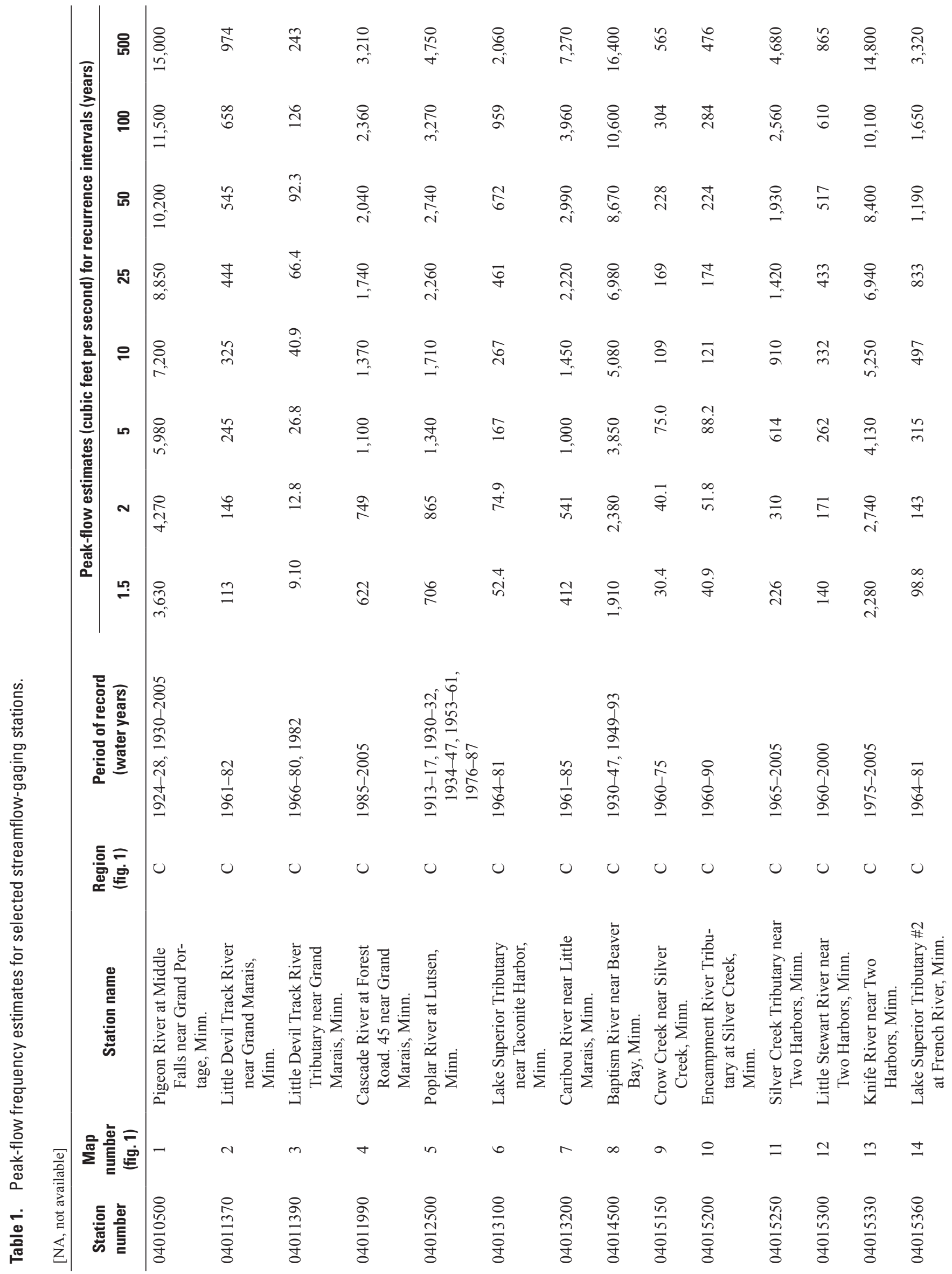




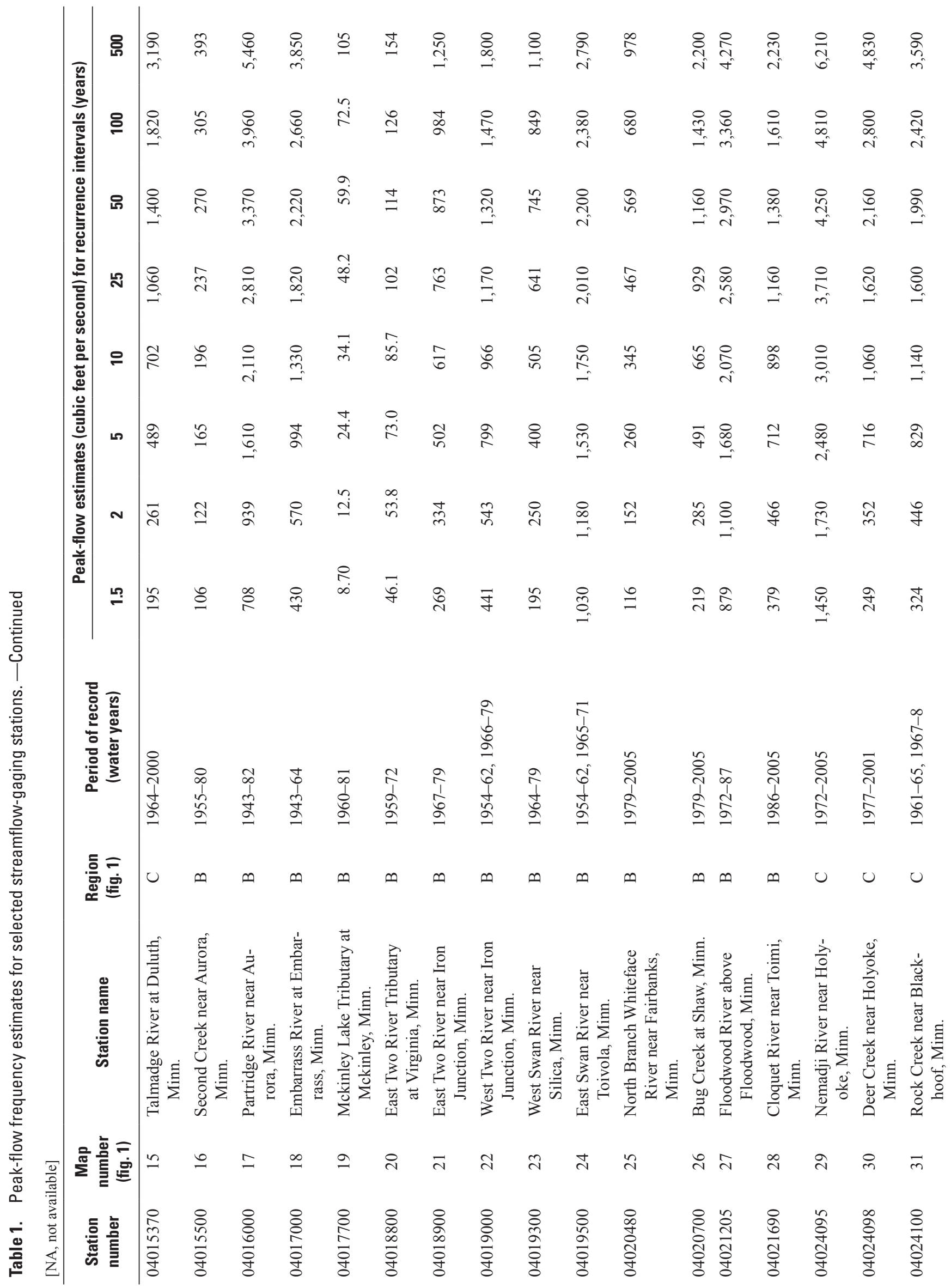




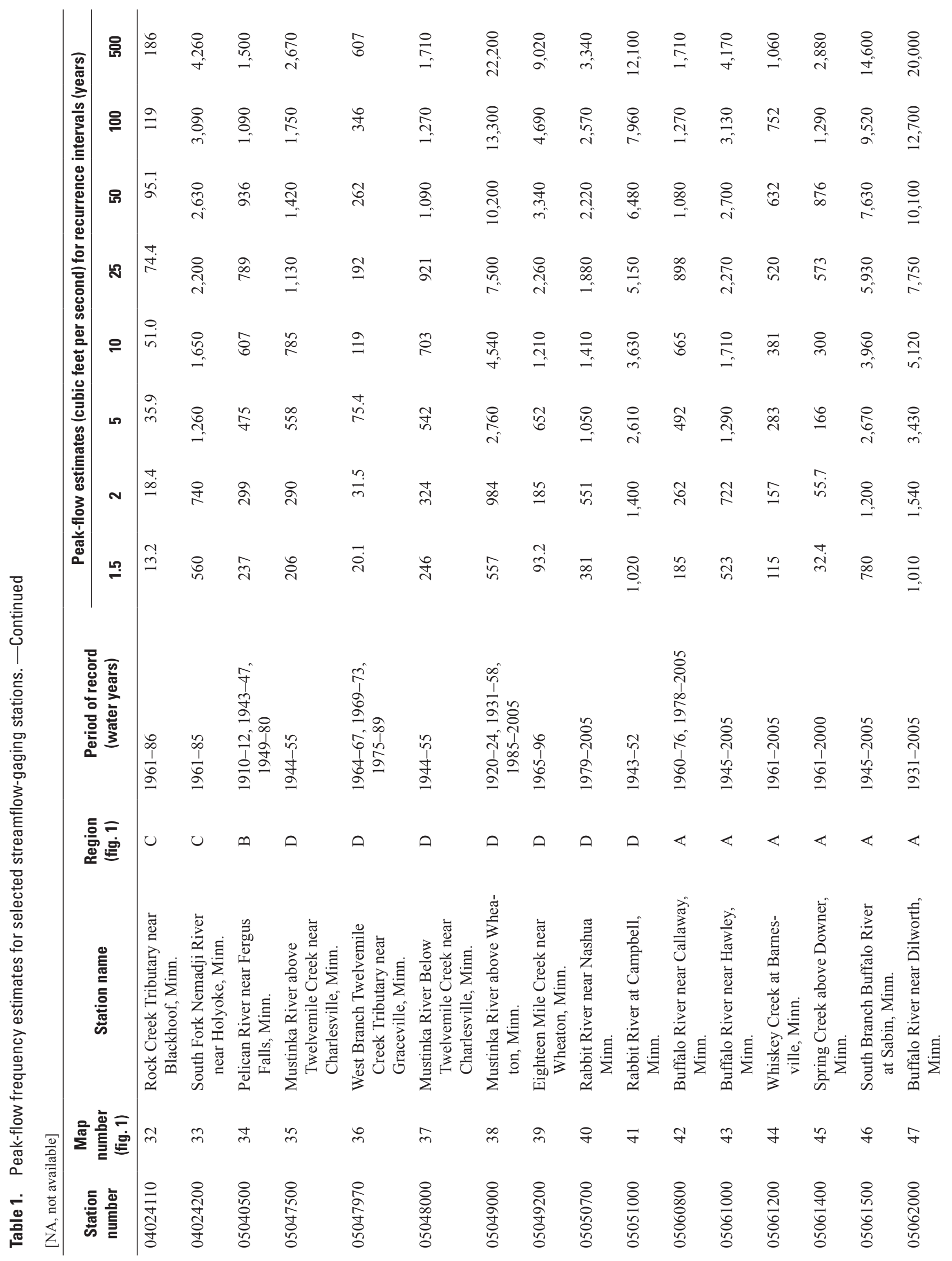




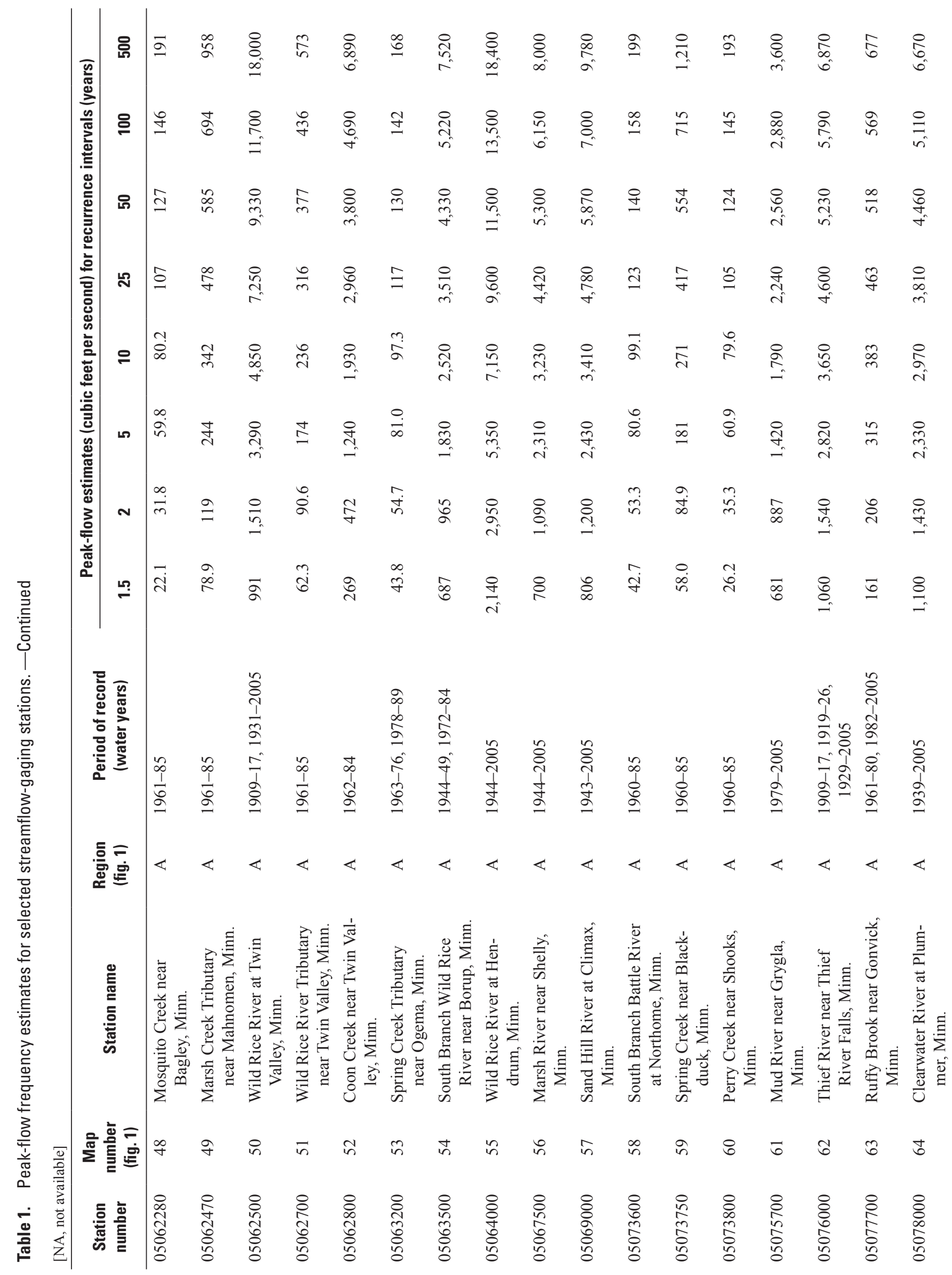




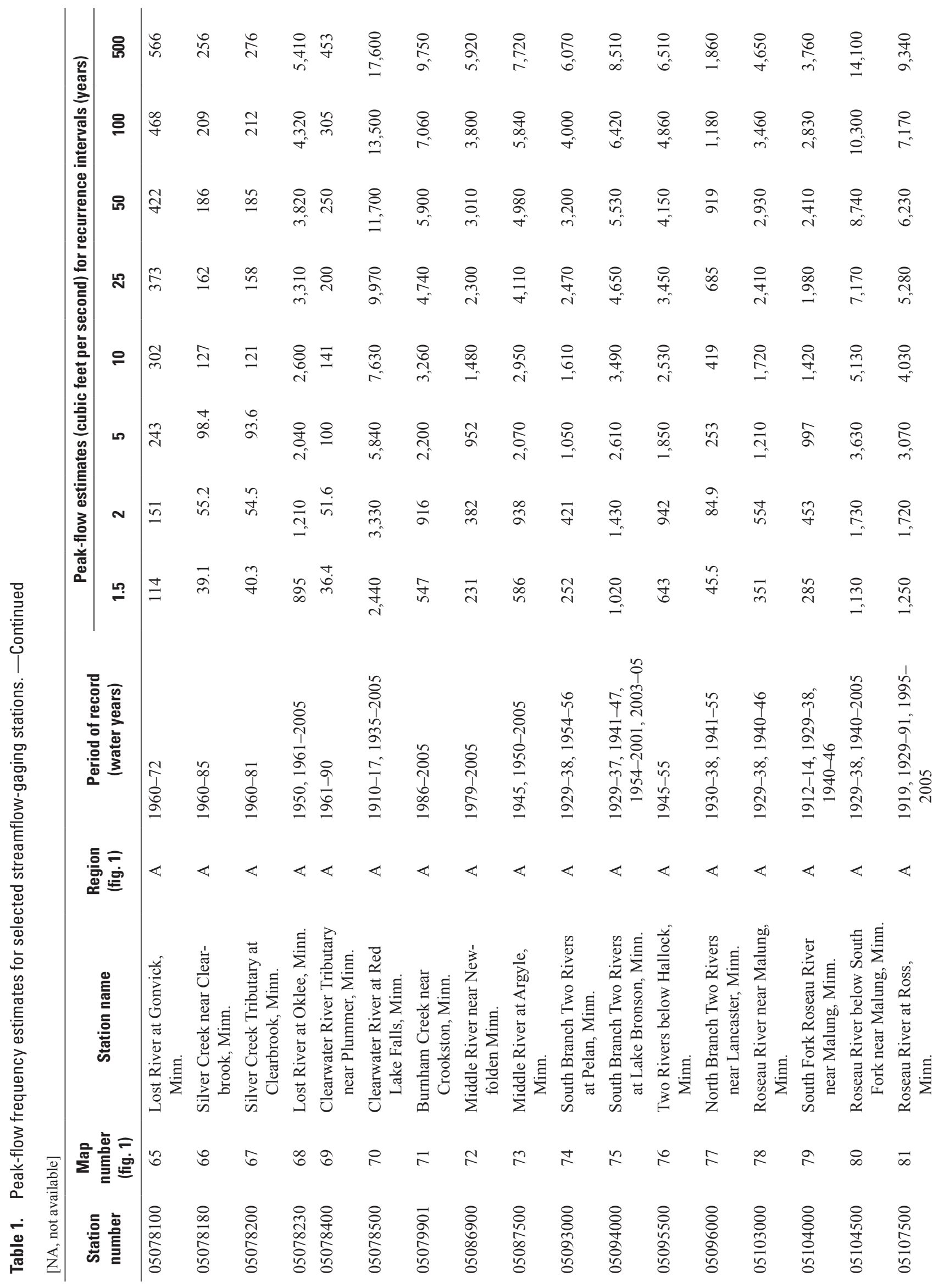




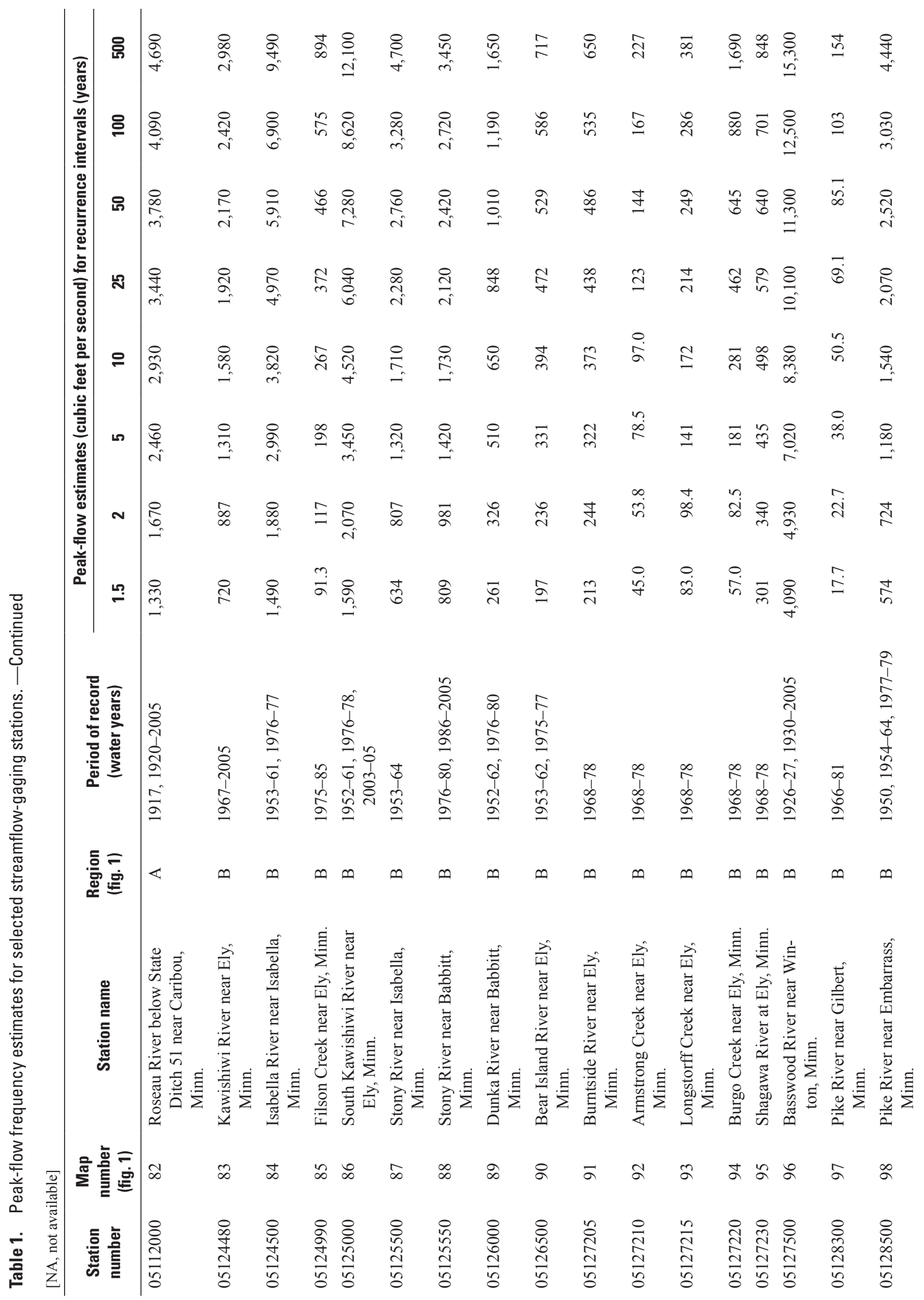




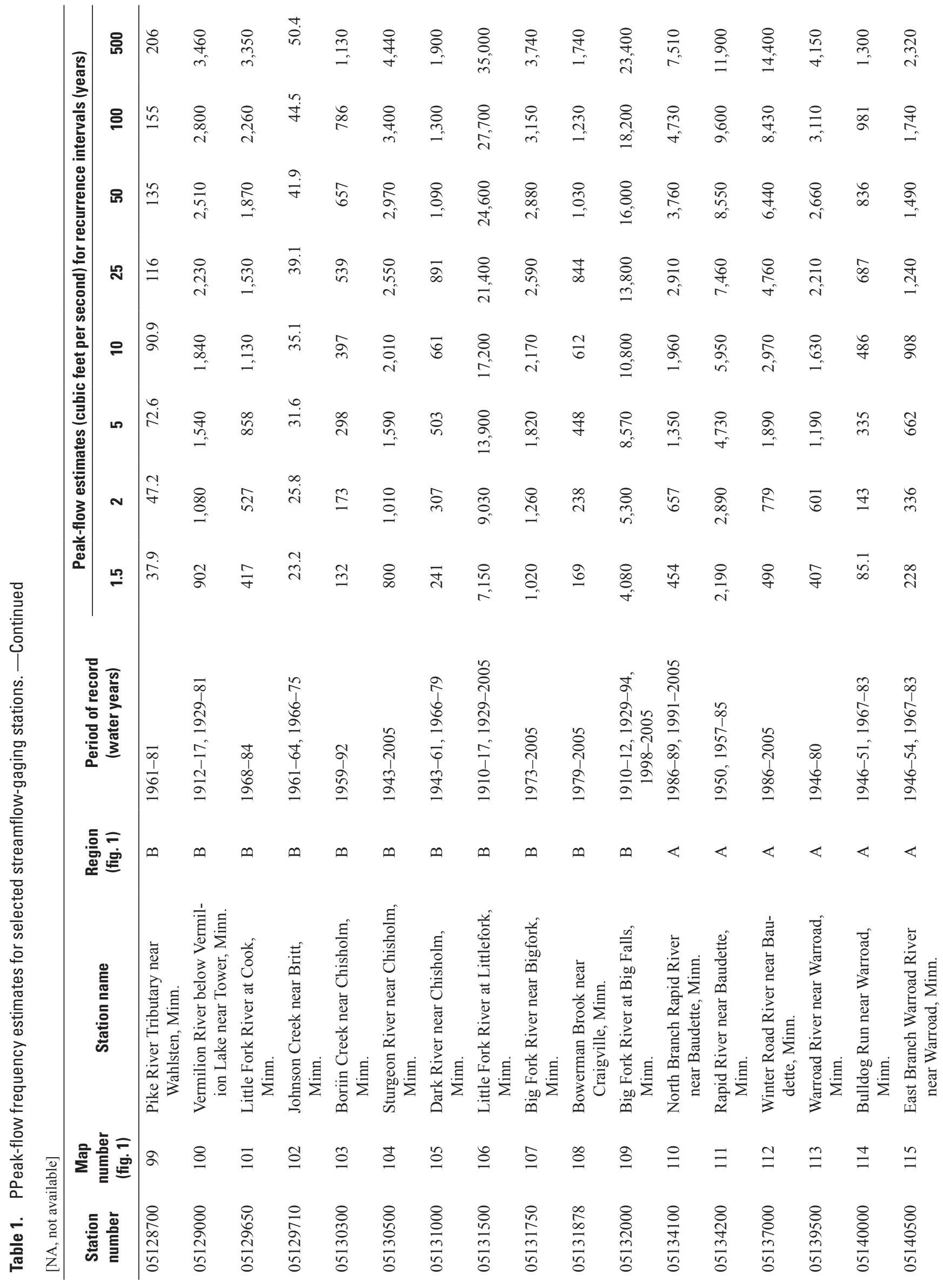




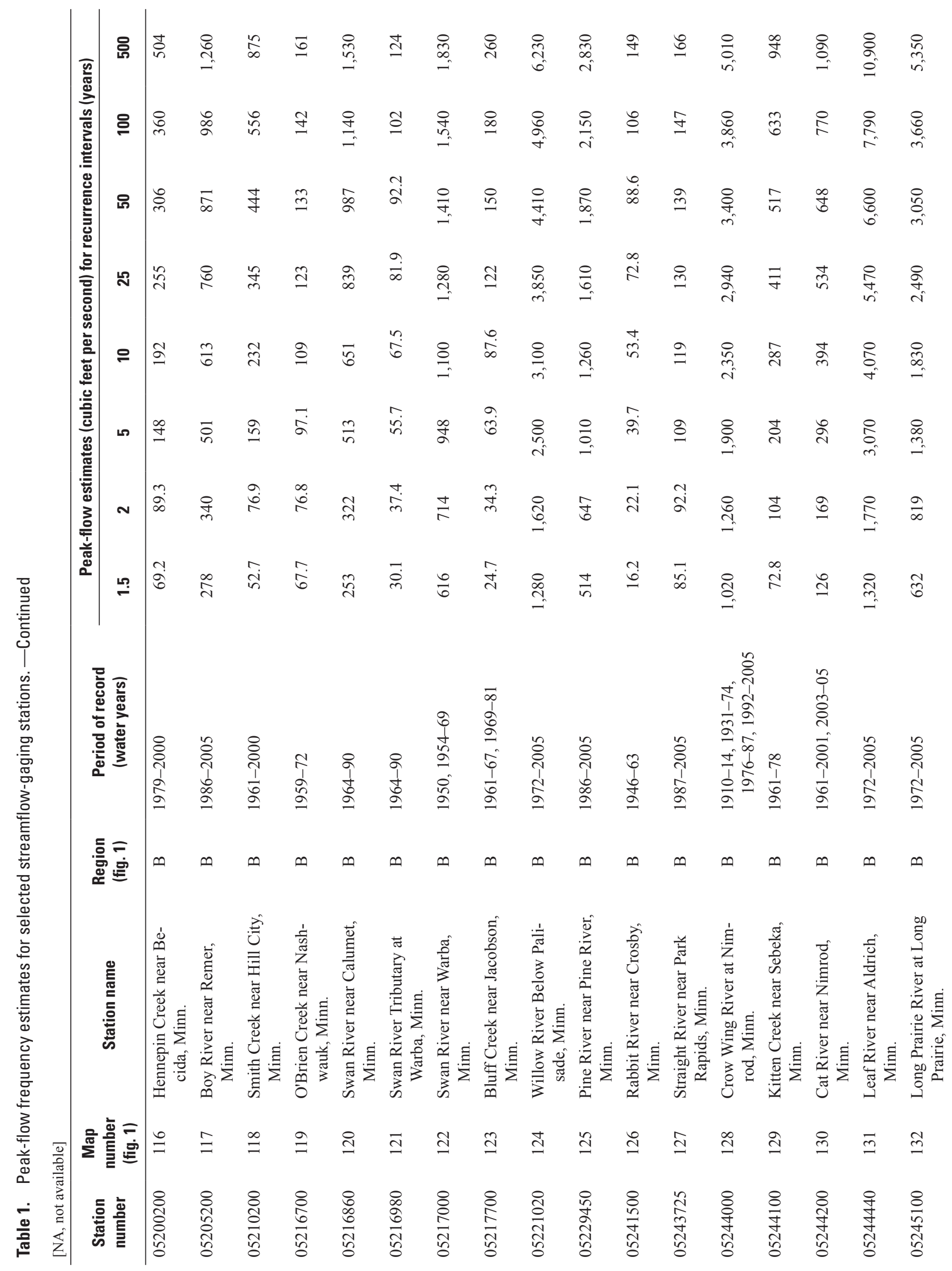




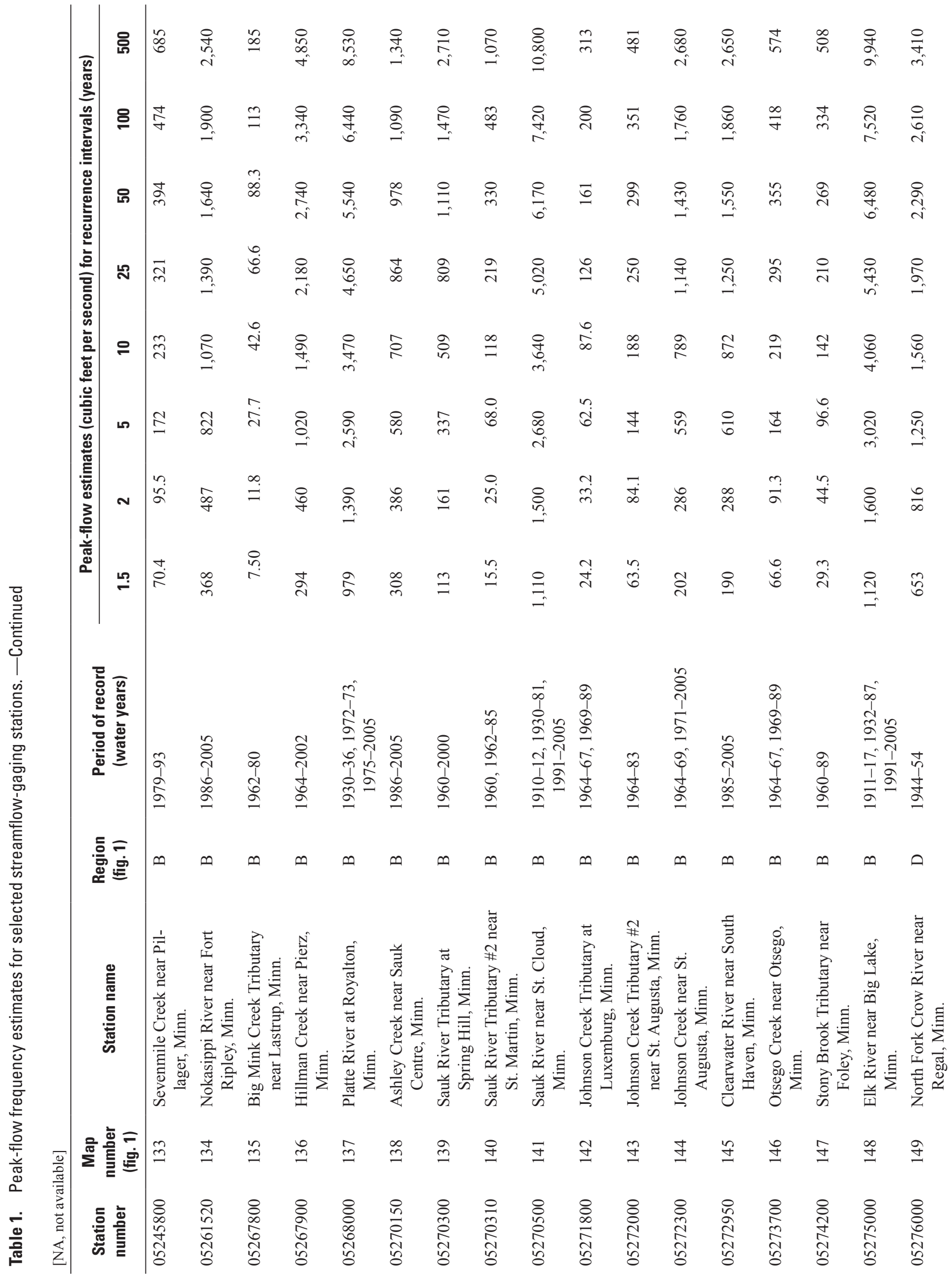




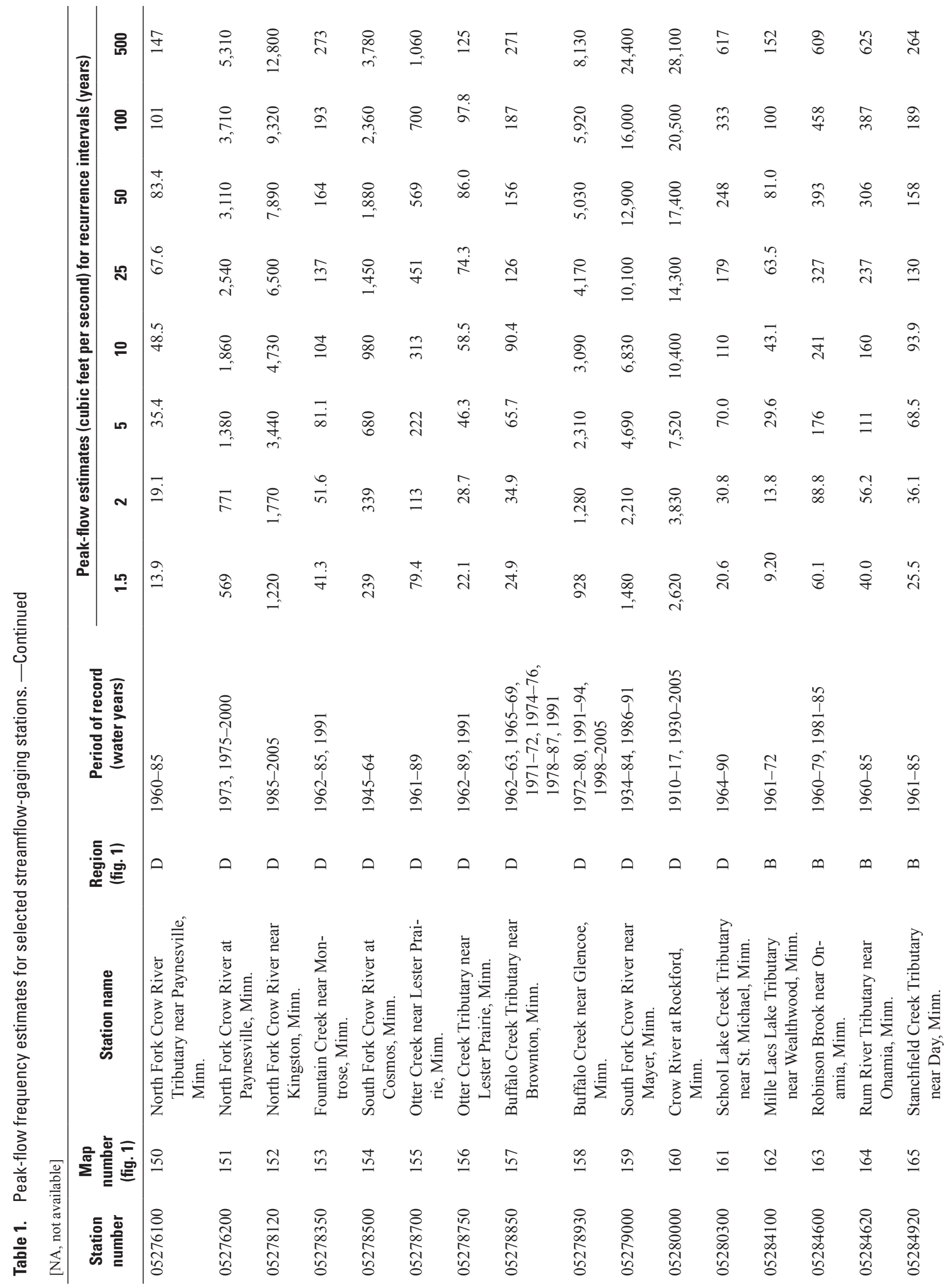




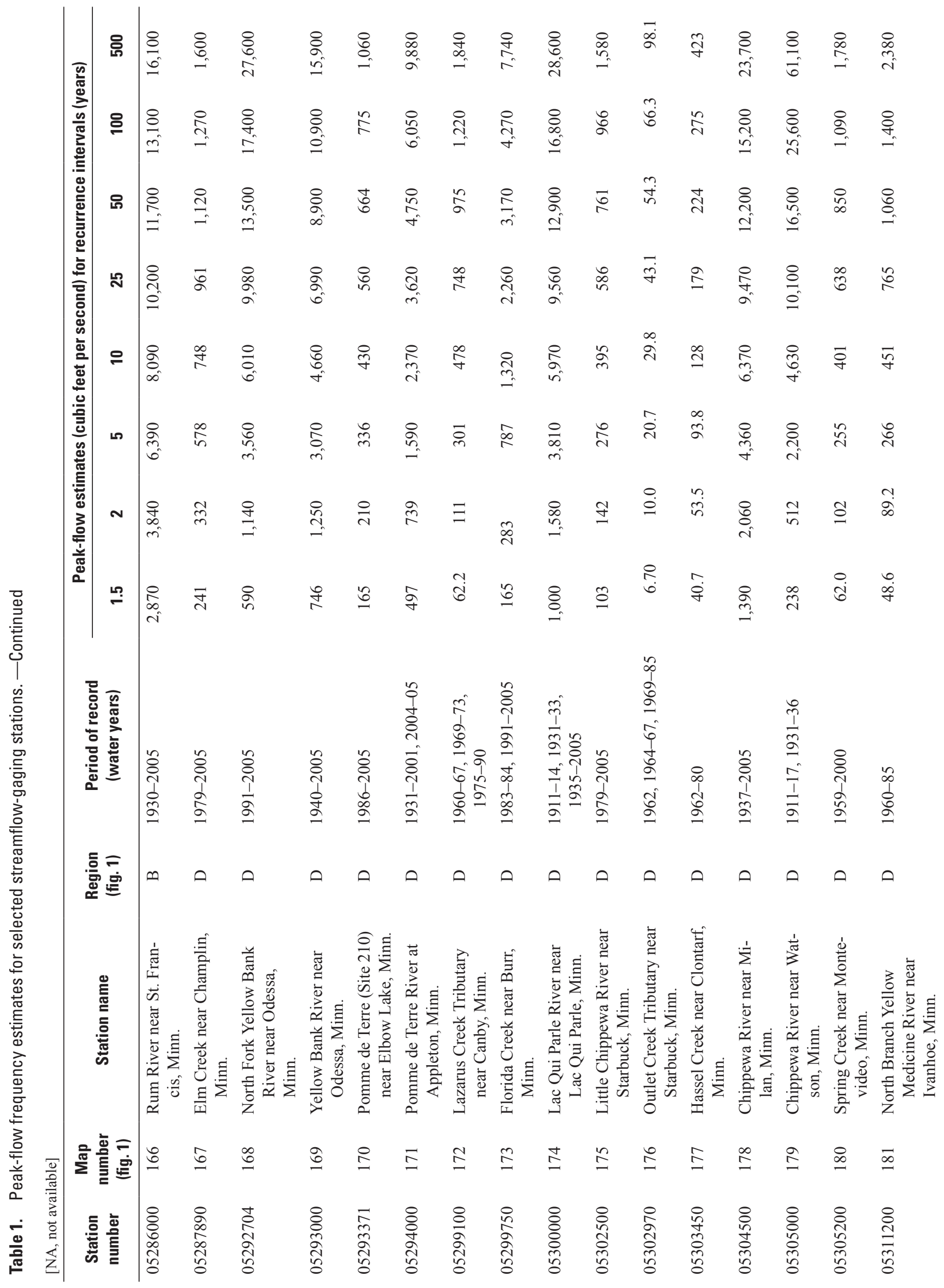




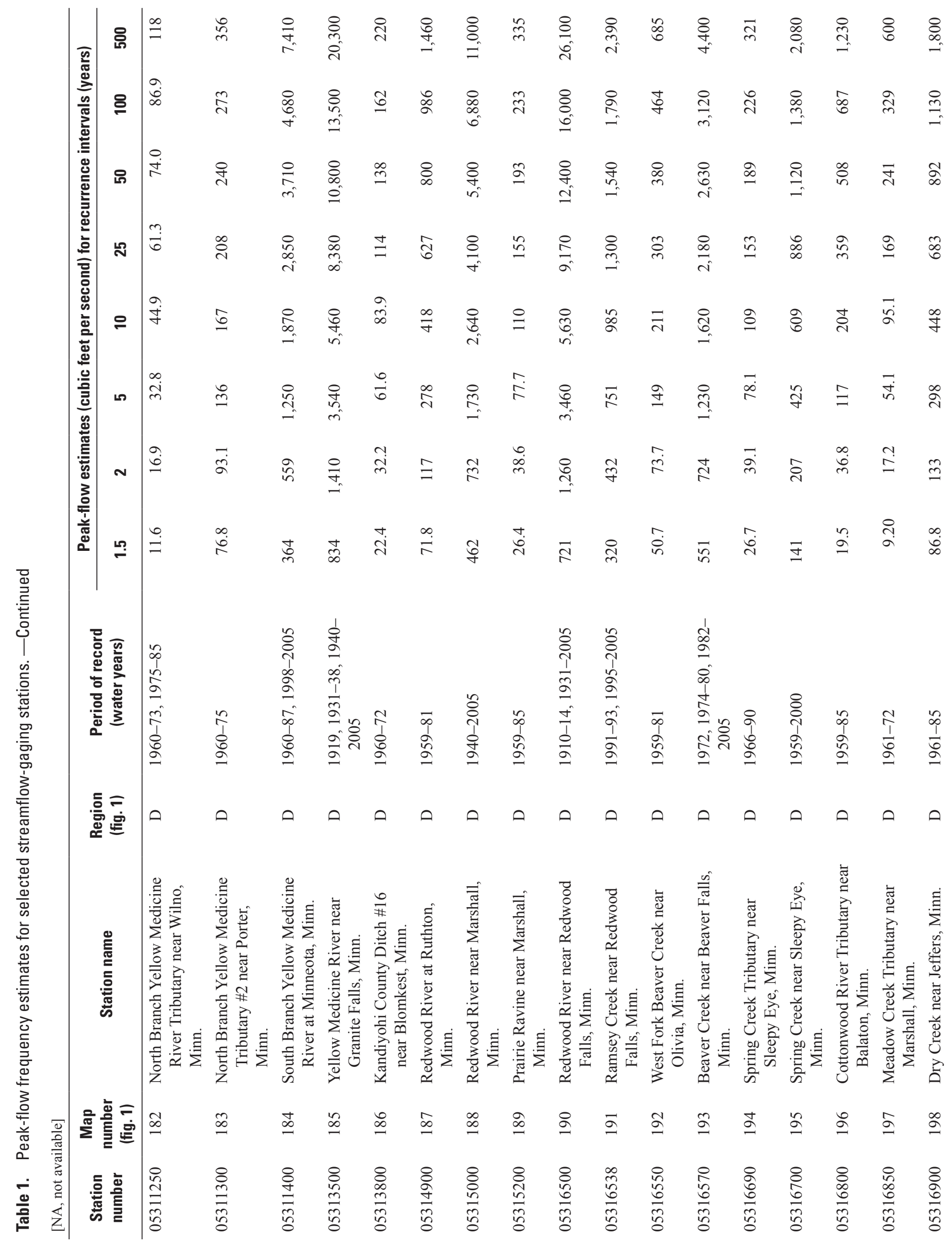




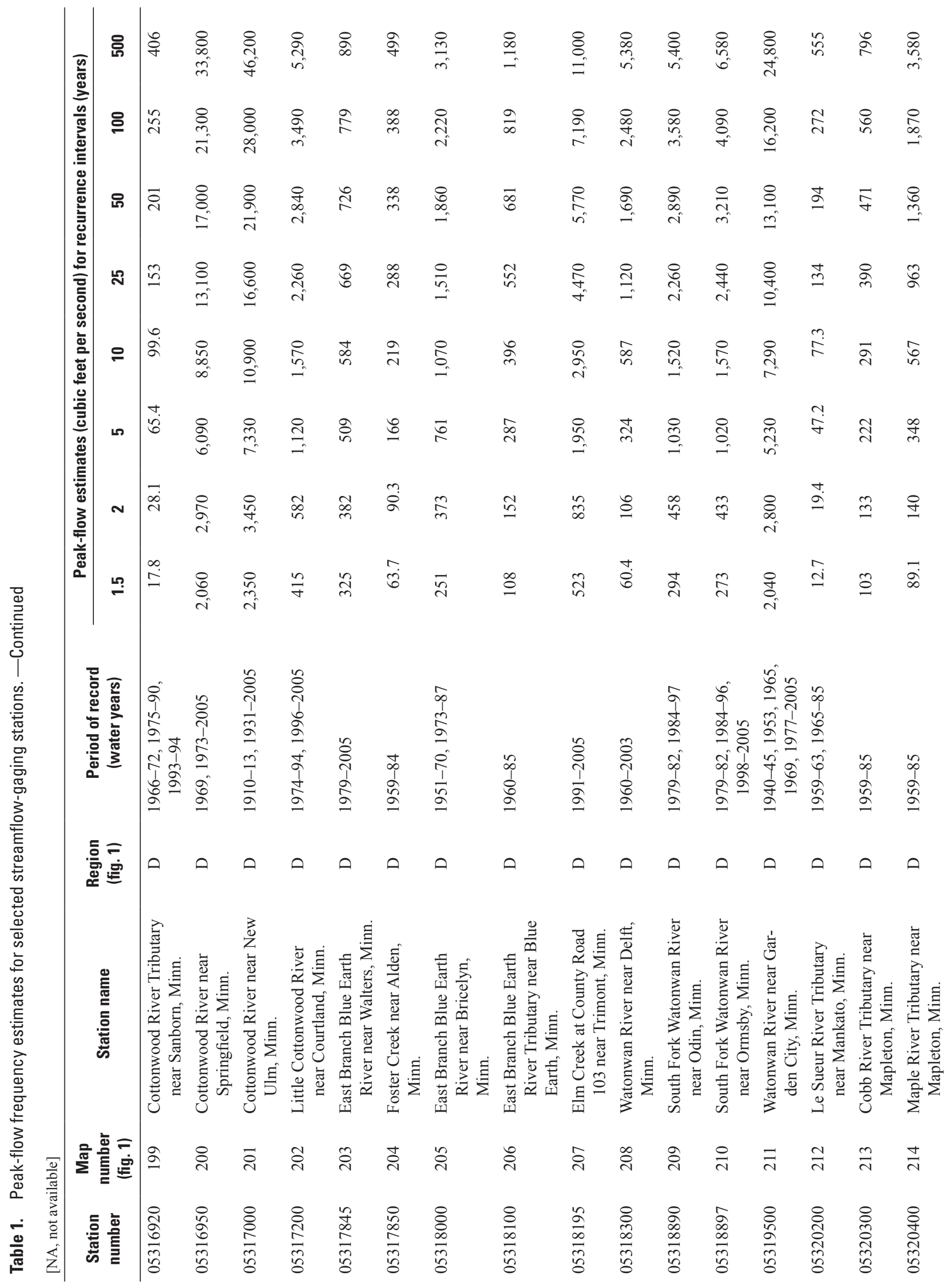




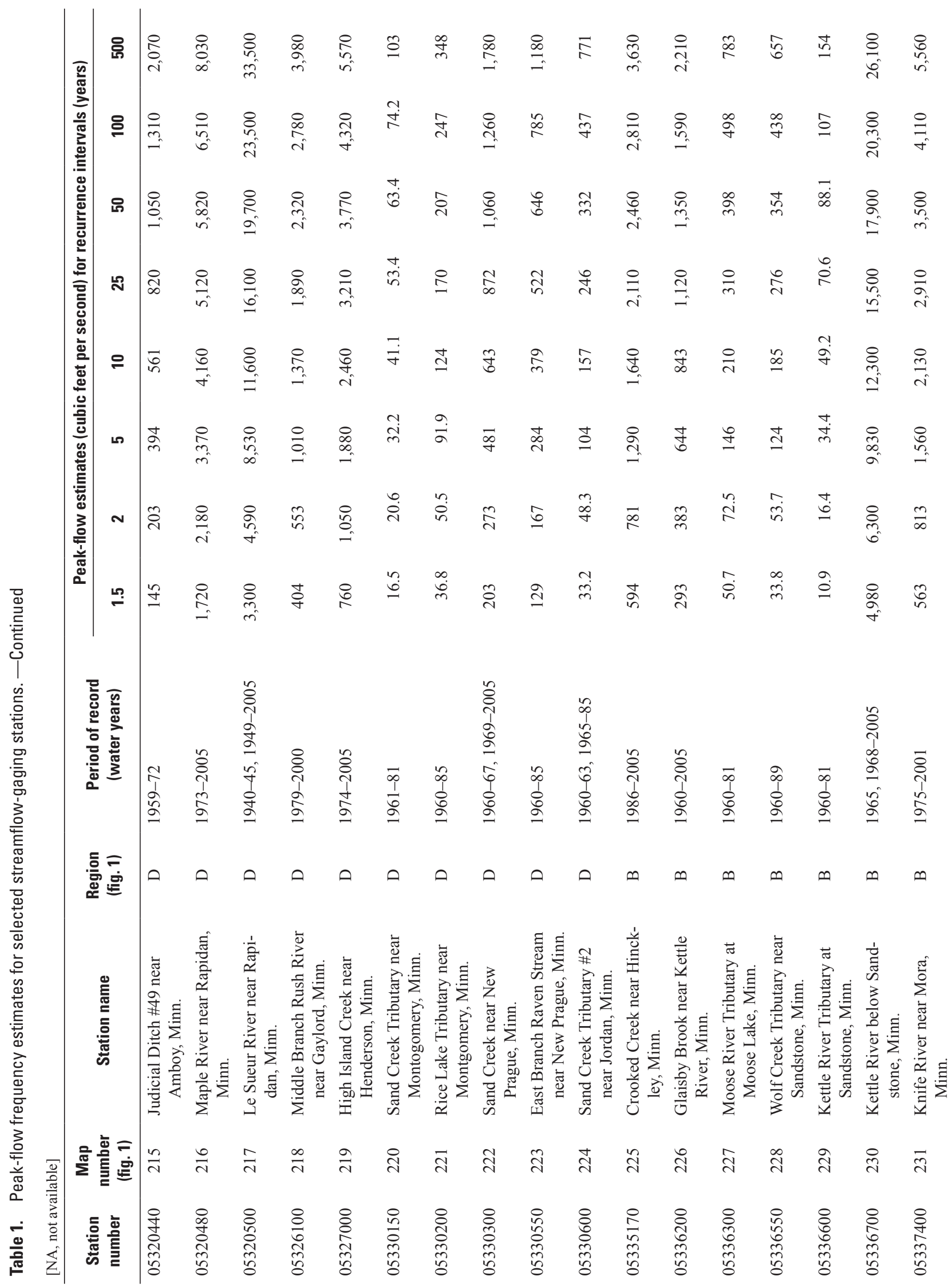




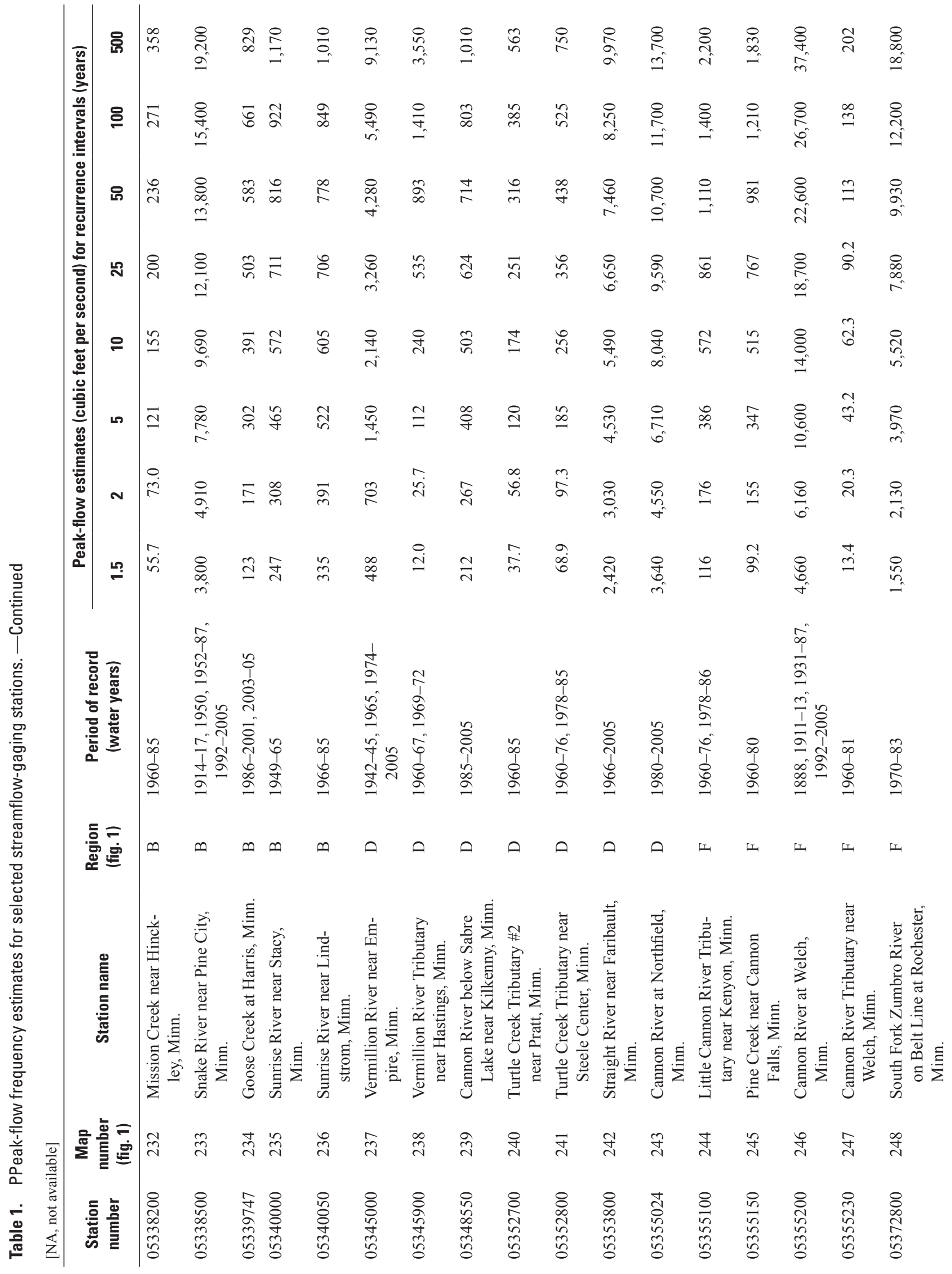




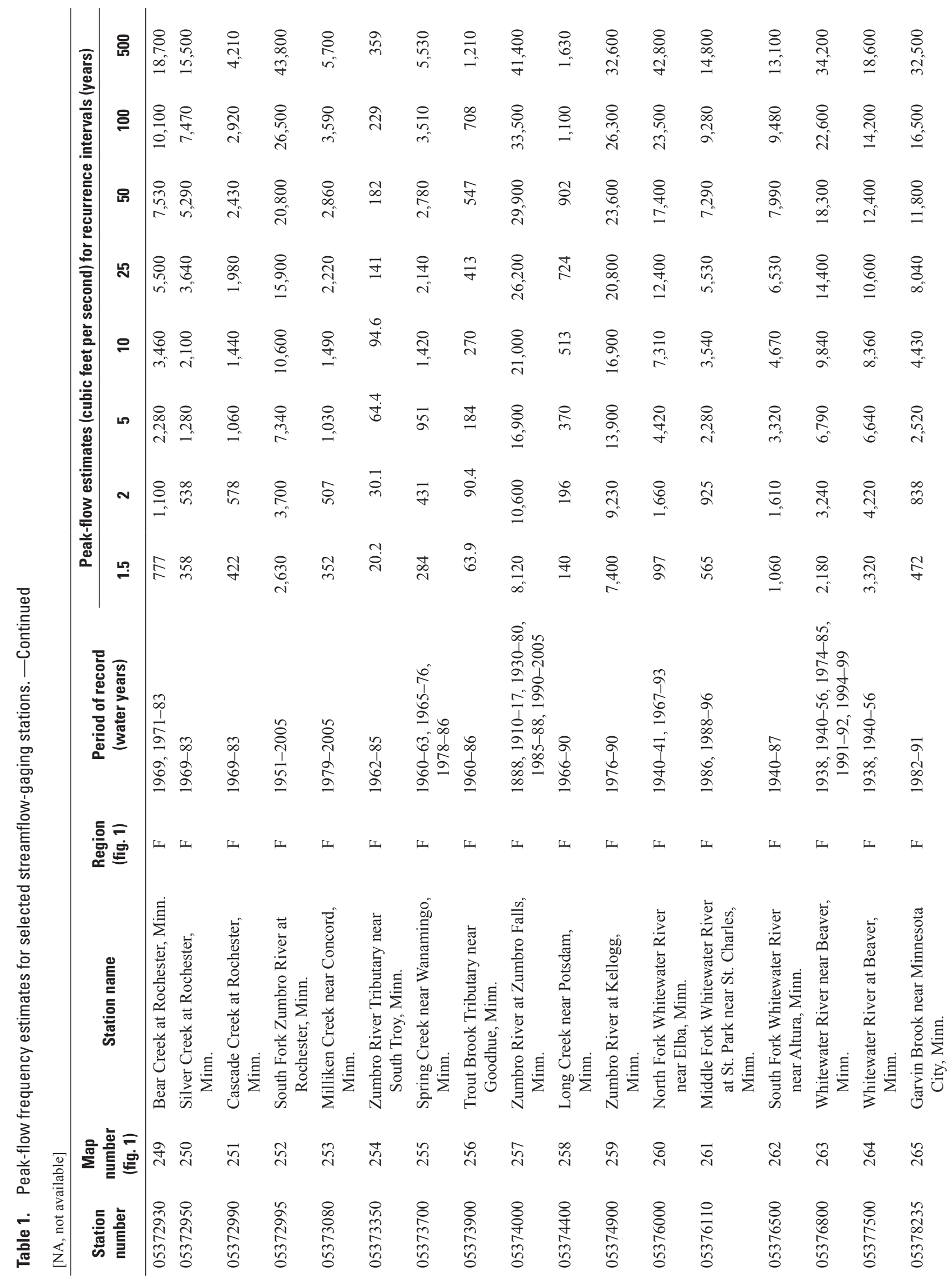




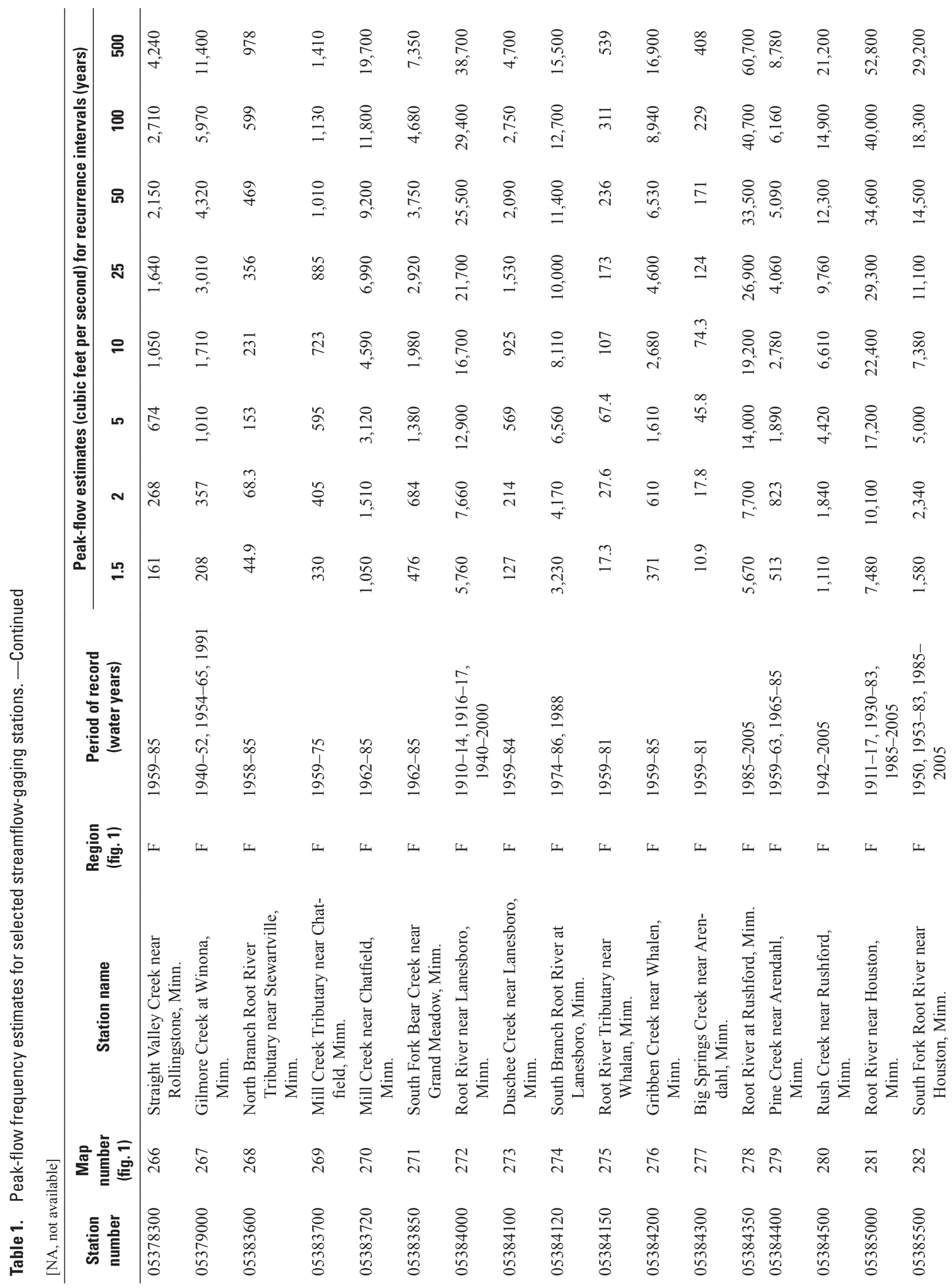




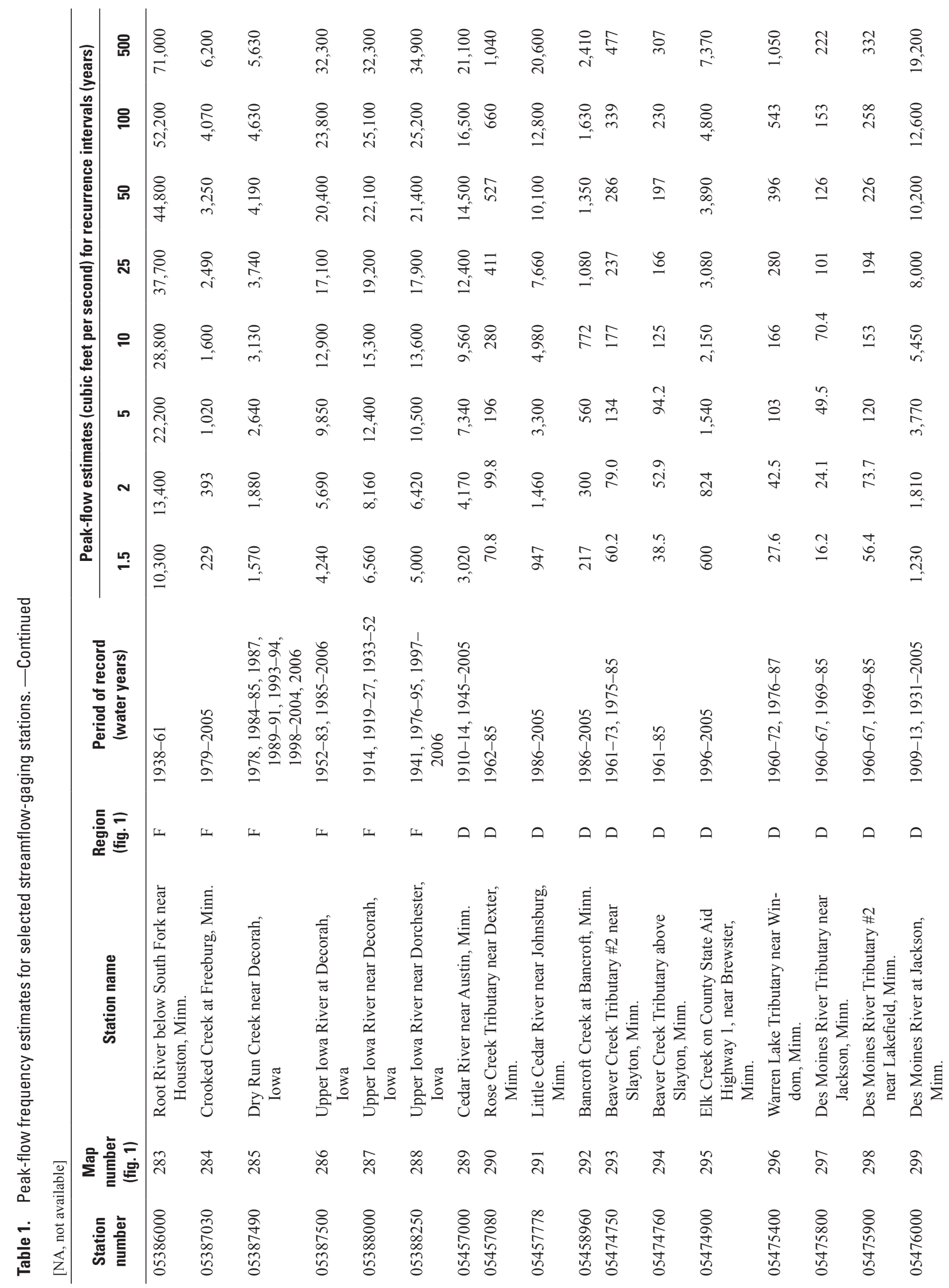




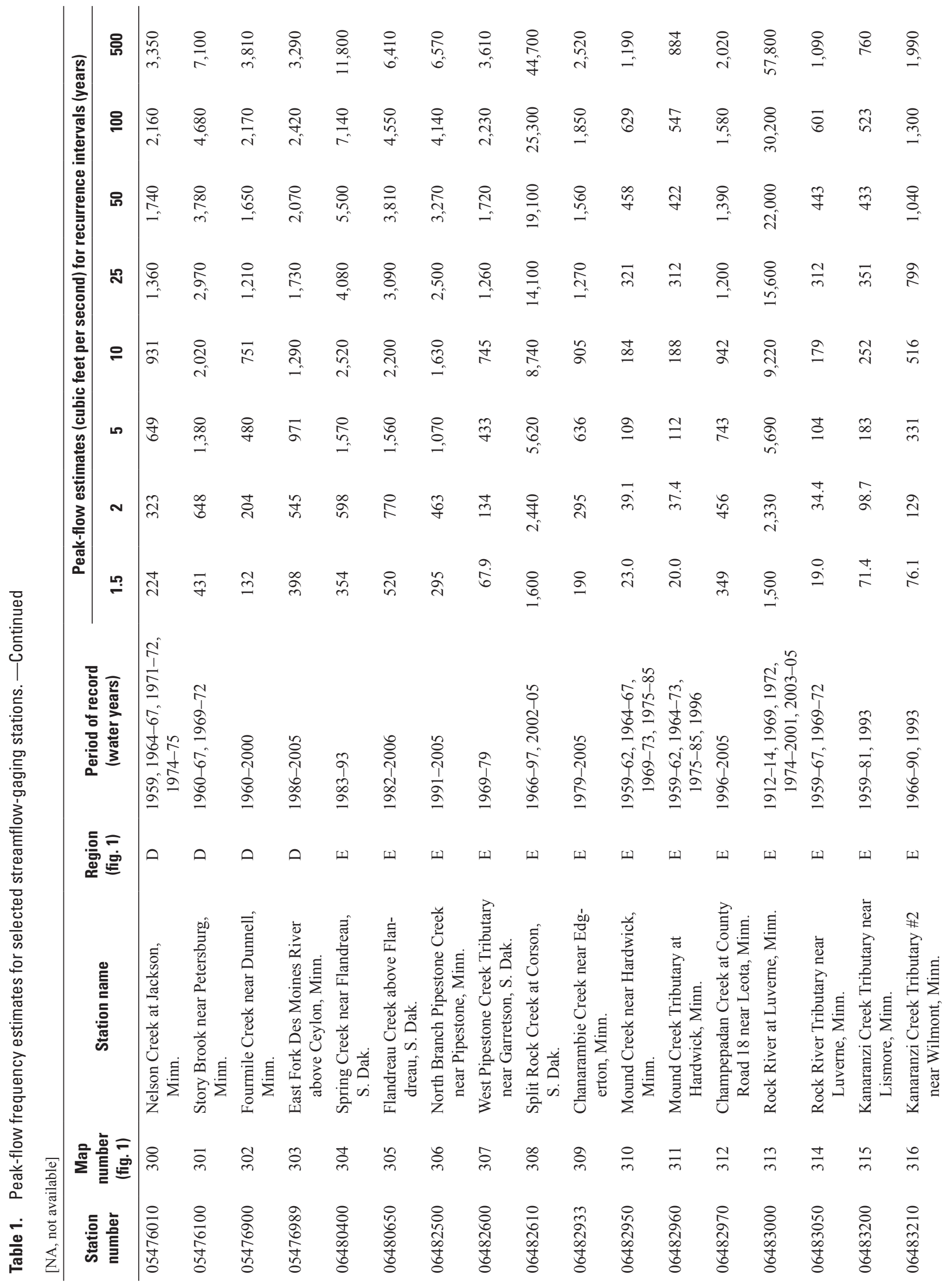




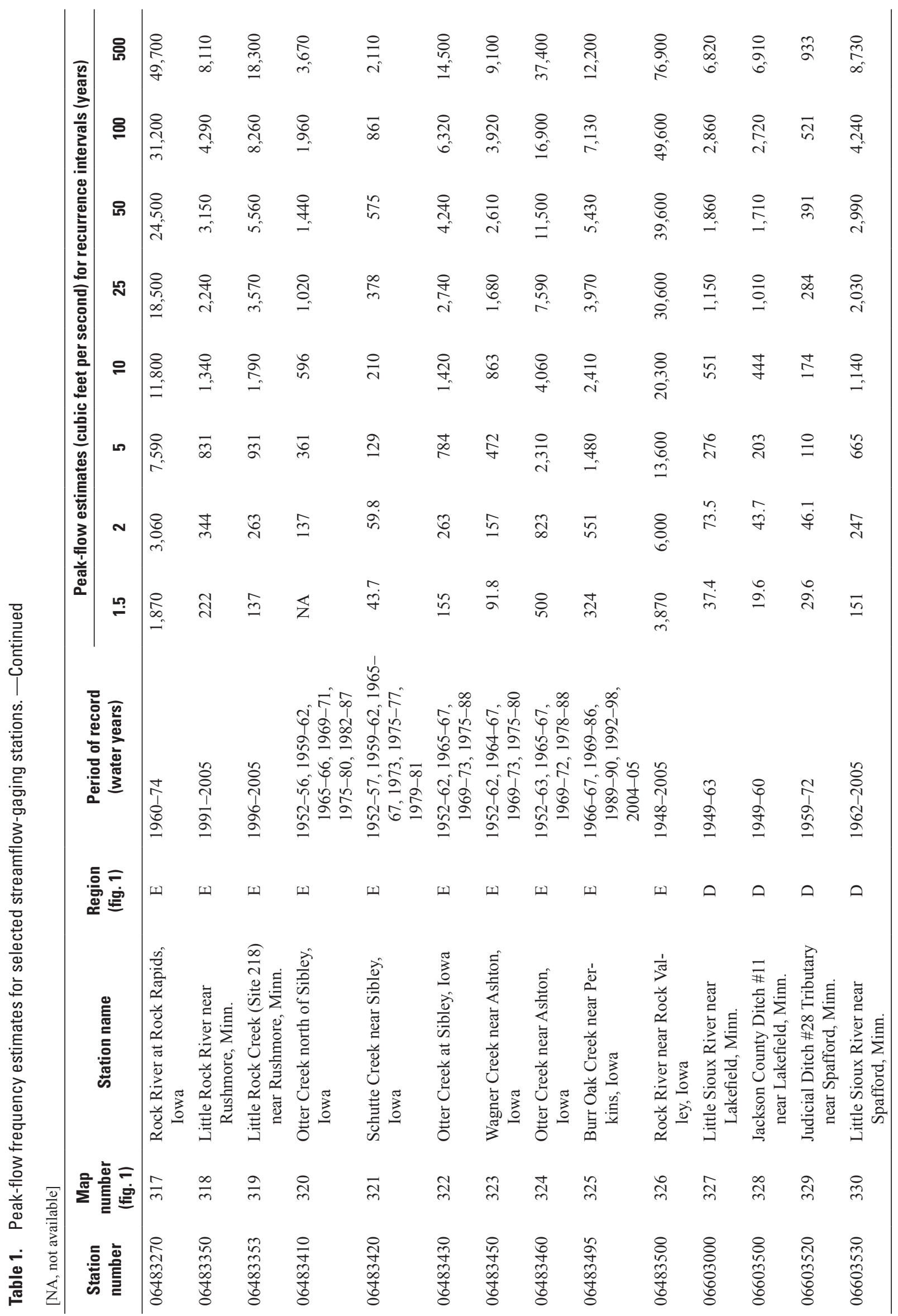


Table 2. Basin characteristics of streamflow-gaging stations used in this report.

$\left[\mathrm{mi}^{2}\right.$, square miles; $\mathrm{ft} / \mathrm{mi}$, feet per mile; in/yr, inches per year]

\begin{tabular}{|c|c|c|c|c|c|c|c|}
\hline $\begin{array}{l}\text { Station } \\
\text { number } \\
\text { (table 1) }\end{array}$ & $\begin{array}{c}\text { Drainage area } \\
\text { (DAREA) } \\
\left(\mathrm{mi}^{2}\right)\end{array}$ & $\begin{array}{c}\text { Main-channel } \\
\text { slope (SLOPE) } \\
\text { (ft/mi) }\end{array}$ & $\begin{array}{c}\text { Lake area } \\
\text { (LAKE) } \\
\text { (percent) }\end{array}$ & $\begin{array}{c}\text { Storage area } \\
\text { (STOR) } \\
\text { (percent) }\end{array}$ & $\begin{array}{c}\text { Soil hydro- } \\
\text { logic group A } \\
\text { (SOILA) } \\
\text { (percent) }\end{array}$ & $\begin{array}{l}\text { Soil hydro- } \\
\text { logic group } \\
\text { D (SOILD) } \\
\text { (percent) }\end{array}$ & $\begin{array}{c}\text { Generalized } \\
\text { mean annual } \\
\text { runoff ( } R O F F) \\
(\mathrm{in} / \mathrm{yr})\end{array}$ \\
\hline 04010500 & 607 & 11.2 & 11.8 & 25.4 & 2.48 & 34.6 & 11.73 \\
\hline 04011370 & 7.36 & 48.6 & 2.85 & 22.9 & .15 & 8.85 & 12.37 \\
\hline 04011390 & .49 & 103 & 0 & 13.2 & .44 & 8.56 & 12.37 \\
\hline 04011990 & 88.7 & 25.0 & 5.46 & 27.1 & 4.53 & 16.7 & 12.18 \\
\hline 04012500 & 113 & 19.9 & 7.39 & 27.0 & 1.32 & 11.9 & 12.32 \\
\hline 04013100 & 1.36 & 235 & 0 & 16.7 & .86 & 15.3 & 12.66 \\
\hline 04013200 & 23.0 & 50.8 & 0 & 15.9 & 2.24 & 13.2 & 12.56 \\
\hline 04014500 & 138 & 40.7 & .67 & 30.2 & 1.48 & 16.9 & 12.47 \\
\hline 04015150 & 1.18 & 105 & 0 & 26.6 & 4.13 & 20.9 & 12.60 \\
\hline 04015200 & .94 & 203 & 0 & 1.68 & 2.52 & 11.1 & 12.65 \\
\hline 04015250 & 3.89 & 142 & 0 & 4.76 & 2.28 & 57.7 & 12.70 \\
\hline 04015300 & 4.82 & 50.7 & 0 & 16.8 & 3.21 & 50.4 & 12.56 \\
\hline 04015330 & 86.0 & 33.1 & 0 & 18.7 & 3.14 & 41.8 & 12.49 \\
\hline 04015360 & 1.18 & 139 & 0 & 4.93 & 2.40 & 74.8 & 12.47 \\
\hline 04015370 & 5.87 & 85.3 & 0 & 13.9 & 1.38 & 31.8 & 12.39 \\
\hline 04015500 & 21.8 & 15.0 & 1.68 & 19.2 & 22.9 & 8.44 & 10.81 \\
\hline 04016000 & 153 & 5.43 & 2.84 & 34.1 & 10.9 & 5.55 & 11.15 \\
\hline 04017000 & 94.5 & 2.89 & 3.51 & 38.2 & 21.2 & 8.77 & 10.82 \\
\hline 04017700 & .23 & 238 & 0 & 4.93 & 4.52 & 6.46 & 10.43 \\
\hline 04018800 & 3.67 & 50.1 & 1.14 & 8.50 & 19.8 & 9.23 & 10.10 \\
\hline 04018900 & 41.7 & 6.67 & 3.32 & 18.2 & 11.6 & 7.51 & 10.12 \\
\hline 04019000 & 66.3 & 8.28 & 3.40 & 19.0 & 11.0 & 7.47 & 9.83 \\
\hline 04019300 & 15.3 & 9.95 & 0 & 15.0 & 8.97 & 5.32 & 9.08 \\
\hline 04019500 & 136 & 5.64 & 1.86 & 30.9 & 12.1 & 6.64 & 9.50 \\
\hline 04020480 & 16.4 & 6.74 & .35 & 46.4 & 1.51 & 3.06 & 11.76 \\
\hline 04020700 & 24.5 & 11.5 & 0 & 30.8 & 3.37 & 1.74 & 11.49 \\
\hline 04021205 & 204 & 3.53 & .52 & 63.9 & 13.8 & 3.53 & 9.54 \\
\hline 04021690 & 40.8 & 15.3 & 1.12 & 54.6 & 7.14 & 1.12 & 12.24 \\
\hline 04024095 & 124 & 14.6 & 1.00 & 28.3 & 32.1 & 13.1 & 11.42 \\
\hline 04024098 & 7.55 & 38.7 & 0 & 17.7 & 9.87 & 40.1 & 11.65 \\
\hline 04024100 & 4.82 & 35.5 & 0 & 5.09 & 1.94 & 54.9 & 11.72 \\
\hline 04024110 & .20 & 44.3 & 0 & 25.6 & 2.00 & 86.0 & 11.85 \\
\hline 04024200 & 20.5 & 35.5 & .27 & 16.8 & 36.4 & 22.7 & 11.64 \\
\hline 05040500 & 477 & 2.22 & 15.3 & 27.8 & 3.02 & .24 & 3.03 \\
\hline 05047500 & 200 & 2.48 & 3.07 & 10.1 & 1.51 & .26 & 2.80 \\
\hline 05047970 & 8.25 & 10.4 & 0 & 2.38 & .11 & 0 & 2.38 \\
\hline 05048000 & 722 & 2.28 & 1.64 & 7.50 & .93 & 3.91 & 2.55 \\
\hline 05049000 & 788 & 2.50 & 1.52 & 7.12 & .93 & 3.93 & 2.52 \\
\hline 05049200 & 50.2 & 4.81 & 0 & 2.34 & 1.03 & 22.0 & 2.15 \\
\hline 05050700 & 113 & 5.21 & 1.35 & 5.12 & 2.85 & 1.39 & 2.58 \\
\hline 05051000 & 252 & 3.89 & .63 & 3.06 & 1.75 & 1.92 & 2.50 \\
\hline
\end{tabular}


Table 2. Basin characteristics of streamflow-gaging stations used in this report.-Continued

[mi², square miles; $\mathrm{ft} / \mathrm{mi}$, feet per mile; in/yr, inches per year]

\begin{tabular}{|c|c|c|c|c|c|c|c|}
\hline $\begin{array}{l}\text { Station } \\
\text { number } \\
\text { (table 1) }\end{array}$ & $\begin{array}{c}\text { Drainage area } \\
(\text { DAREA }) \\
\left(\mathrm{mi}^{2}\right)\end{array}$ & $\begin{array}{c}\text { Main-channel } \\
\text { slope (SLOPE) } \\
\text { (ft/mi) }\end{array}$ & $\begin{array}{c}\text { Lake area } \\
\text { (LAKE) } \\
\text { (percent) }\end{array}$ & $\begin{array}{c}\text { Storage area } \\
\text { (STOR) } \\
\text { (percent) }\end{array}$ & $\begin{array}{l}\text { Soil hydro- } \\
\text { logic group A } \\
\text { (SOILA) } \\
\text { (percent) }\end{array}$ & $\begin{array}{l}\text { Soil hydro- } \\
\text { logic group } \\
\text { D (SOILD) } \\
\text { (percent) }\end{array}$ & $\begin{array}{c}\text { Generalized } \\
\text { mean annual } \\
\text { runoff (ROFF) } \\
(\mathrm{in} / \mathrm{yr})\end{array}$ \\
\hline 05060800 & 91.9 & 4.54 & 13.0 & 33.0 & 9.69 & 0.34 & 3.48 \\
\hline 05061000 & 336 & 5.59 & 5.91 & 18.5 & 3.77 & .09 & 3.07 \\
\hline 05061200 & 62.0 & 16.1 & 3.67 & 14.7 & 3.45 & 0 & 2.63 \\
\hline 05061400 & 6.19 & 14.2 & 0 & 6.16 & 29.6 & 0 & 2.39 \\
\hline 05061500 & 461 & 7.11 & 1.20 & 8.74 & 8.60 & 2.18 & 2.38 \\
\hline 05062000 & 987 & 6.45 & 2.66 & 11.6 & 7.37 & 1.28 & 2.59 \\
\hline 05062280 & 4.38 & 10.9 & 0 & 5.23 & 7.00 & 0 & 4.04 \\
\hline 05062470 & 12.9 & 3.48 & 0 & 5.86 & 1.00 & 0 & 2.91 \\
\hline 05062500 & 934 & 3.90 & 4.08 & 18.6 & 6.84 & .62 & 3.41 \\
\hline 05062700 & 5.01 & 11.8 & 0 & 9.93 & 32.8 & .30 & 2.55 \\
\hline 05062800 & 45.9 & 12.7 & .23 & 9.42 & 21.4 & .14 & 2.58 \\
\hline 05063200 & 5.45 & 15.3 & .54 & 20.0 & 1.45 & 0 & 3.12 \\
\hline 05063500 & 249 & 6.53 & .68 & 7.50 & 6.83 & .54 & 2.67 \\
\hline 05064000 & 1,570 & 4.20 & 2.56 & 13.7 & 7.94 & 3.55 & 3.04 \\
\hline 05067500 & 236 & 4.90 & .10 & 4.82 & 9.71 & 18.2 & 2.34 \\
\hline 05069000 & 460 & 4.76 & 1.92 & 9.53 & 4.74 & 19.4 & 2.68 \\
\hline 05073600 & 2.81 & 6.62 & 2.23 & 28.6 & .13 & 7.61 & 6.03 \\
\hline 05073750 & 8.30 & 15.4 & .42 & 32.0 & 1.00 & 4.99 & 5.55 \\
\hline 05073800 & 3.36 & 7.22 & 0 & 66.6 & 1.00 & 2.56 & 5.51 \\
\hline 05075700 & 183 & 2.39 & 0 & 53.7 & 1.01 & .17 & 3.77 \\
\hline 05076000 & 967 & 1.74 & 1.38 & 53.6 & 2.10 & 2.54 & 3.52 \\
\hline 05077700 & 46.7 & 10.1 & 2.28 & 18.2 & 23.0 & 1.18 & 3.97 \\
\hline 05078000 & 554 & 3.33 & 1.34 & 22.9 & 15.2 & .71 & 3.74 \\
\hline 05078100 & 53.3 & 9.02 & 5.42 & 21.1 & .05 & 1.36 & 3.67 \\
\hline 05078180 & 5.56 & 37.4 & 0 & 20.9 & 0 & 3.00 & 3.79 \\
\hline 05078200 & 5.90 & 21.8 & 1.18 & 16.6 & 0 & .26 & 3.82 \\
\hline 05078230 & 249 & 5.02 & 1.24 & 17.1 & 4.76 & .61 & 3.52 \\
\hline 05078400 & 8.00 & 5.26 & 0 & 4.79 & 3.58 & 0 & 2.87 \\
\hline 05078500 & 1,360 & 3.41 & 1.78 & 17.7 & 10.4 & 1.12 & 3.45 \\
\hline 05079901 & 118 & 10.1 & .32 & 12.6 & 8.16 & 25.3 & 2.44 \\
\hline 05086900 & 85.6 & 3.54 & 0 & 15.3 & 10.8 & 0 & 3.04 \\
\hline 05087500 & 252 & 4.19 & .03 & 11.7 & 15.3 & .11 & 2.84 \\
\hline 05093000 & 272 & 3.39 & .13 & 13.3 & 6.85 & 1.34 & 3.28 \\
\hline 05094000 & 558 & 3.04 & .15 & 12.3 & 6.32 & 1.28 & 3.28 \\
\hline 05095500 & 691 & 3.81 & .13 & 11.9 & 6.05 & 1.77 & 3.19 \\
\hline 05096000 & 31.6 & 3.80 & 0 & 13.4 & 10.9 & .66 & 3.20 \\
\hline 05103000 & 210 & 3.49 & .35 & 60.4 & 4.93 & 2.78 & 4.16 \\
\hline 05104000 & 214 & 3.25 & .03 & 36.5 & 5.93 & 5.58 & 3.76 \\
\hline 05104500 & 428 & 3.63 & .19 & 47.9 & 5.39 & 4.25 & 3.96 \\
\hline 05107500 & 1,010 & 2.94 & .15 & 43.6 & 3.89 & 3.96 & 4.14 \\
\hline 05112000 & 1,410 & 2.13 & .31 & 43.7 & 3.67 & 3.53 & 4.05 \\
\hline
\end{tabular}


Table 2. Basin characteristics of streamflow-gaging stations used in this report-Continued

$\left[\mathrm{mi}^{2}\right.$, square miles; ft/mi, feet per mile; in/yr, inches per year]

\begin{tabular}{|c|c|c|c|c|c|c|c|}
\hline $\begin{array}{l}\text { Station } \\
\text { number } \\
\text { (table 1) }\end{array}$ & $\begin{array}{c}\text { Drainage area } \\
\text { (DAREA) } \\
\left(\mathrm{mi}^{2}\right)\end{array}$ & $\begin{array}{l}\text { Main-channel } \\
\text { slope (SLOPE) } \\
\text { (ft/mi) }\end{array}$ & $\begin{array}{c}\text { Lake area } \\
\text { (LAKE) } \\
\text { (percent) }\end{array}$ & $\begin{array}{c}\text { Storage area } \\
\text { (STOR) } \\
\text { (percent) }\end{array}$ & $\begin{array}{l}\text { Soil hydro- } \\
\text { logic group A } \\
\text { (SOILA) } \\
\text { (percent) }\end{array}$ & $\begin{array}{l}\text { Soil hydro- } \\
\text { logic group } \\
\text { D (SOILD) } \\
\text { (percent) }\end{array}$ & $\begin{array}{c}\text { Generalized } \\
\text { mean annual } \\
\text { runoff ( } R O F F) \\
\text { (in/yr) }\end{array}$ \\
\hline 05124480 & 251 & 6.38 & 11.4 & 27.2 & 1.45 & 34.8 & 11.67 \\
\hline 05124500 & 340 & 7.28 & 4.66 & 29.8 & 7.16 & 15.4 & 11.92 \\
\hline 05124990 & 9.51 & 13.8 & 1.94 & 25.9 & 0 & 39.0 & 11.34 \\
\hline 05125000 & 442 & 6.44 & 5.72 & 30.1 & 6.28 & 18.5 & 11.82 \\
\hline 05125500 & 175 & 10.3 & 4.02 & 47.9 & 7.40 & 1.50 & 11.89 \\
\hline 05125550 & 211 & 9.85 & 3.53 & 46.3 & 7.85 & 1.55 & 11.83 \\
\hline 05126000 & 57.1 & 12.9 & .28 & 36.3 & 15.2 & 9.05 & 11.36 \\
\hline 05126500 & 65.8 & 4.53 & 8.97 & 38.2 & 3.40 & 23.7 & 10.95 \\
\hline 05127205 & 68.8 & 5.98 & 21.4 & 32.1 & 3.34 & 25.1 & 10.71 \\
\hline 05127210 & 5.83 & 43.8 & 0 & 28.8 & 4.00 & 30.0 & 10.86 \\
\hline 05127215 & 8.09 & 29.8 & 9.55 & 30.1 & 5.64 & 25.0 & 10.90 \\
\hline 05127220 & 2.98 & 49.3 & 1.00 & 17.7 & 4.00 & 30.0 & 10.93 \\
\hline 05127230 & 99.6 & 1.65 & 19.3 & 32.8 & 3.56 & 25.1 & 10.76 \\
\hline 05127500 & 1,410 & 4.42 & 9.13 & 33.4 & 5.54 & 20.7 & 11.52 \\
\hline 05128300 & 1.08 & 71.1 & 0 & 7.95 & 35.0 & 12.0 & 10.29 \\
\hline 05128500 & 114 & 3.59 & .65 & 34.8 & 25.5 & 4.15 & 10.17 \\
\hline 05128700 & 2.88 & 8.35 & 3.26 & 42.1 & 9.30 & 2.35 & 10.47 \\
\hline 05129000 & 488 & 1.86 & 17.1 & 38.9 & 10.0 & 13.7 & 10.20 \\
\hline 05129650 & 63.4 & 3.23 & 1.81 & 53.6 & 2.90 & 13.3 & 9.89 \\
\hline 05129710 & 8.14 & 4.19 & 15.1 & 44.7 & 28.4 & .57 & 9.79 \\
\hline 05130300 & 14.6 & 12.8 & .30 & 26.7 & 12.0 & 4.53 & 9.35 \\
\hline 05130500 & 186 & 7.09 & 4.15 & 32.6 & 23.3 & 2.23 & 9.12 \\
\hline 05131000 & 56.2 & 13.9 & 10.5 & 30.3 & 52.1 & 2.94 & 9.62 \\
\hline 05131500 & 1,700 & 1.63 & 2.12 & 40.3 & 10.5 & 17.6 & 8.76 \\
\hline 05131750 & 605 & .67 & 9.32 & 44.4 & 8.19 & 7.63 & 6.73 \\
\hline 05131878 & 23.2 & 10.0 & 0 & 41.5 & 1.61 & 12.4 & 7.29 \\
\hline 05132000 & 1,500 & .98 & 5.24 & 46.5 & 6.79 & 12.8 & 7.10 \\
\hline 05134100 & 174 & 3.05 & 0 & 94.3 & 5.39 & .70 & 4.82 \\
\hline 05134200 & 581 & 2.80 & 0 & 95.0 & 2.32 & 5.69 & 4.90 \\
\hline 05137000 & 141 & 4.23 & .21 & 86.5 & 4.74 & .96 & 5.14 \\
\hline 05139500 & 168 & 5.44 & .13 & 77.4 & 5.23 & 1.10 & 4.53 \\
\hline 05140000 & 11.2 & 8.20 & 0 & 18.5 & .72 & .22 & 4.68 \\
\hline 05140500 & 51.1 & 5.12 & 0 & 64.4 & 6.07 & 1.35 & 4.77 \\
\hline 05200200 & 41.5 & 5.55 & 2.19 & 13.8 & 2.38 & 4.79 & 4.58 \\
\hline 05205200 & 288 & 1.75 & 18.2 & 35.3 & 7.32 & 0 & 6.61 \\
\hline 05210200 & 7.83 & 31.0 & .82 & 22.4 & 2.00 & 0 & 8.01 \\
\hline 05216700 & 12.2 & 40.5 & 5.66 & 16.2 & 16.4 & 5.89 & 8.78 \\
\hline 05216860 & 113 & 7.06 & 9.61 & 26.0 & 11.9 & 4.20 & 8.82 \\
\hline 05216980 & 4.07 & 26.4 & 2.03 & 29.5 & 8.94 & .10 & 8.91 \\
\hline 05217000 & 245 & 2.92 & 7.74 & 29.8 & 10.2 & 3.43 & 8.68 \\
\hline 05217700 & 1.45 & 7.58 & 0 & 28.3 & 54.5 & 1.00 & 8.92 \\
\hline
\end{tabular}


Table 2. Basin characteristics of streamflow-gaging stations used in this report.-Continued

$\left[\mathrm{mi}^{2}\right.$, square miles; $\mathrm{ft} / \mathrm{mi}$, feet per mile; in/yr, inches per year $]$

\begin{tabular}{|c|c|c|c|c|c|c|c|}
\hline $\begin{array}{l}\text { Station } \\
\text { number } \\
\text { (table 1) }\end{array}$ & $\begin{array}{c}\text { Drainage area } \\
\text { (DAREA) } \\
\left(\mathrm{mi}^{2}\right)\end{array}$ & $\begin{array}{c}\text { Main-channel } \\
\text { slope (SLOPE) } \\
\text { (ft/mi) }\end{array}$ & $\begin{array}{c}\text { Lake area } \\
\text { (LAKE) } \\
\text { (percent) }\end{array}$ & $\begin{array}{c}\text { Storage area } \\
\text { (STOR) } \\
\text { (percent) }\end{array}$ & $\begin{array}{l}\text { Soil hydro- } \\
\text { logic group A } \\
\text { (SOILA) } \\
\text { (percent) }\end{array}$ & $\begin{array}{c}\text { Soil hydro- } \\
\text { logic group } \\
\text { D (SOILD) } \\
\text { (percent) }\end{array}$ & $\begin{array}{c}\text { Generalized } \\
\text { mean annual } \\
\text { runoff }(R O F F) \\
(\text { in } / y r)\end{array}$ \\
\hline 05221020 & 513 & 1.91 & 2.60 & 43.9 & 11.3 & 2.36 & 8.13 \\
\hline 05229450 & 266 & 3.06 & 7.37 & 27.0 & 22.3 & 0 & 6.34 \\
\hline 05241500 & 8.92 & 11.6 & 23.7 & 34.8 & 1.12 & 7.88 & 7.83 \\
\hline 05243725 & 59.0 & 5.81 & 1.65 & 9.31 & 43.5 & .16 & 4.52 \\
\hline 05244000 & 917 & 2.78 & 5.10 & 27.9 & 35.2 & .22 & 4.95 \\
\hline 05244100 & 18.5 & 9.25 & .56 & 19.7 & 7.08 & 0 & 4.87 \\
\hline 05244200 & 47.9 & 5.54 & .21 & 31.6 & 10.6 & 0 & 5.02 \\
\hline 05244440 & 858 & 3.95 & 1.13 & 22.8 & 15.4 & .03 & 4.62 \\
\hline 05245100 & 448 & 1.50 & 10.7 & 25.3 & 5.45 & 0 & 4.15 \\
\hline 05245800 & 19.4 & 13.1 & .07 & 14.2 & 37.5 & 0 & 6.12 \\
\hline 05261520 & 188 & 3.64 & 4.75 & 28.6 & 18.4 & .04 & 7.17 \\
\hline 05267800 & 1.27 & 19.6 & 0 & 19.2 & 3.11 & 0 & 6.57 \\
\hline 05267900 & 45.5 & 8.23 & 0 & 29.8 & 1.57 & 0 & 6.79 \\
\hline 05268000 & 431 & 3.71 & 1.97 & 26.7 & 18.8 & .29 & 6.57 \\
\hline 05270150 & 123 & 4.46 & 2.06 & 14.3 & 14.8 & .06 & 4.10 \\
\hline 05270300 & 7.16 & 10.3 & 0 & 4.53 & 0 & 0 & 4.25 \\
\hline 05270310 & .32 & 70.3 & 0 & 1.84 & 3.41 & .05 & 4.42 \\
\hline 05270500 & 1,040 & 2.36 & 4.11 & 16.8 & 11.4 & .54 & 4.44 \\
\hline 05271800 & 6.96 & 5.21 & 2.43 & 21.8 & 9.08 & 0 & 4.77 \\
\hline 05272000 & 15.3 & 10.6 & 1.37 & 21.5 & 15.7 & .08 & 4.82 \\
\hline 05272300 & 45.1 & 10.7 & .58 & 21.4 & 29.2 & .23 & 4.88 \\
\hline 05272950 & 79.9 & 11.4 & 2.60 & 16.9 & 3.88 & .77 & 4.59 \\
\hline 05273700 & 3.22 & 21.2 & 0 & 9.47 & 0 & 1.72 & 5.52 \\
\hline 05274200 & 2.40 & 9.43 & 0 & 22.2 & 0 & 0 & 5.67 \\
\hline 05275000 & 554 & 2.86 & 1.31 & 20.2 & 30.3 & .18 & 5.65 \\
\hline 05276000 & 210 & 3.83 & .88 & 16.8 & 11.6 & .72 & 4.03 \\
\hline 05276100 & .67 & 34.6 & 0 & 8.97 & .11 & 0 & 4.24 \\
\hline 05276200 & 237 & 4.07 & .80 & 17.0 & 12.7 & .78 & 4.04 \\
\hline 05278120 & 775 & 3.17 & 4.69 & 20.1 & 11.5 & 1.26 & 4.16 \\
\hline 05278350 & 6.52 & 2.72 & 1.74 & 24.9 & 0 & 4.28 & 4.95 \\
\hline 05278500 & 234 & 2.77 & 6.34 & 14.3 & .07 & .49 & 4.13 \\
\hline 05278700 & 31.2 & 2.69 & 1.70 & 13.9 & 0 & 1.73 & 4.75 \\
\hline 05278750 & 1.20 & 13.8 & 0 & 2.48 & 0 & 3.00 & 4.89 \\
\hline 05278850 & 9.20 & 7.21 & 8.84 & 16.3 & 0 & 0 & 4.66 \\
\hline 05278930 & 373 & 2.00 & 1.45 & 7.51 & 0 & .15 & 4.50 \\
\hline 05279000 & 1,150 & 1.87 & 3.14 & 11.6 & .04 & .80 & 4.51 \\
\hline 05280000 & 2,640 & 2.61 & 5.80 & 21.6 & 8.11 & 1.57 & 4.44 \\
\hline 05280300 & 4.26 & 7.48 & 13.4 & 24.1 & 0 & 1.11 & 5.36 \\
\hline 05284100 & .56 & 33.5 & 0 & 20.7 & 49.8 & 0 & 8.27 \\
\hline 05284620 & 2.79 & 10.9 & 0 & 32.5 & 0 & .12 & 7.18 \\
\hline 05284920 & 1.23 & 44.6 & 0 & 15.7 & 1.00 & 5.00 & 7.01 \\
\hline
\end{tabular}


Table 2. Basin characteristics of streamflow-gaging stations used in this report.-Continued

$\left[\mathrm{mi}^{2}\right.$, square miles; $\mathrm{ft} / \mathrm{mi}$, feet per mile; in/yr, inches per year]

\begin{tabular}{|c|c|c|c|c|c|c|c|}
\hline $\begin{array}{l}\text { Station } \\
\text { number } \\
\text { (table 1) }\end{array}$ & $\begin{array}{c}\text { Drainage area } \\
\text { (DAREA) } \\
\left(\mathrm{mi}^{2}\right)\end{array}$ & $\begin{array}{c}\text { Main-channel } \\
\text { slope (SLOPE) } \\
\text { (ft/mi) }\end{array}$ & $\begin{array}{c}\text { Lake area } \\
\text { (LAKE) } \\
\text { (percent) }\end{array}$ & $\begin{array}{c}\text { Storage area } \\
\text { (STOR) } \\
\text { (percent) }\end{array}$ & $\begin{array}{l}\text { Soil hydro- } \\
\text { logic group A } \\
\text { (SOILA) } \\
\text { (percent) }\end{array}$ & $\begin{array}{l}\text { Soil hydro- } \\
\text { logic group } \\
\text { D (SOILD) } \\
\text { (percent) }\end{array}$ & $\begin{array}{c}\text { Generalized } \\
\text { mean annual } \\
\text { runoff ( } R O F F) \\
(\mathrm{in} / \mathrm{yr})\end{array}$ \\
\hline 05286000 & 1,390 & 2.92 & 16.1 & 38.8 & 13.1 & 0.86 & 7.21 \\
\hline 05287890 & 86.9 & 5.89 & 1.84 & 22.0 & .03 & 1.44 & 5.65 \\
\hline 05292704 & 209 & 18.1 & .66 & 5.12 & 1.00 & 7.64 & 2.44 \\
\hline 05293000 & 460 & 11.9 & .74 & 6.29 & .78 & 6.76 & 2.57 \\
\hline 05293371 & 317 & 4.05 & 14.0 & 24.5 & 3.86 & 0 & 3.23 \\
\hline 05294000 & 865 & 2.26 & 6.77 & 14.6 & 4.90 & .01 & 2.99 \\
\hline 05299100 & 3.03 & 55.2 & 0 & 4.87 & 0 & 2.86 & 2.96 \\
\hline 05299750 & 73.4 & 7.53 & .16 & 6.50 & .36 & .81 & 2.61 \\
\hline 05300000 & 960 & 7.27 & .86 & 6.17 & .30 & 4.27 & 2.85 \\
\hline 05302500 & 95.4 & 6.18 & 10.6 & 21.9 & 1.12 & 0 & 3.52 \\
\hline 05302970 & .15 & 63.6 & 0 & 5.39 & 1.00 & 0 & 3.33 \\
\hline 05303450 & 7.36 & 35.3 & 0 & 14.9 & 2.02 & 0 & 3.33 \\
\hline 05304500 & 1,870 & 2.84 & 5.04 & 13.9 & 5.28 & .48 & 3.43 \\
\hline 05305000 & 2,040 & 2.75 & 4.62 & 12.9 & 4.98 & .44 & 3.42 \\
\hline 05305200 & 16.7 & 4.61 & 0 & .86 & 0 & .05 & 3.38 \\
\hline 05311200 & 14.8 & 8.50 & 0 & 4.97 & .02 & 0 & 3.00 \\
\hline 05311250 & .27 & 77.2 & 0 & 0 & 0 & 0 & 3.13 \\
\hline 05311300 & 3.82 & 38.1 & 0 & 2.18 & 0 & .34 & 3.11 \\
\hline 05311400 & 115 & 12.2 & .90 & 5.82 & .02 & 1.59 & 3.36 \\
\hline 05313500 & 668 & 6.86 & .73 & 4.57 & .19 & 1.99 & 3.37 \\
\hline 05313800 & .86 & 11.7 & 0 & .12 & 0 & 0 & 3.96 \\
\hline 05314900 & 5.79 & 27.0 & 0 & 2.60 & .60 & 0 & 3.54 \\
\hline 05315000 & 259 & 8.38 & 2.39 & 7.89 & .21 & .11 & 3.50 \\
\hline 05315200 & 5.52 & 8.12 & 0 & 3.84 & 0 & 2.58 & 3.67 \\
\hline 05316500 & 624 & 6.68 & 1.27 & 5.01 & .56 & .97 & 3.66 \\
\hline 05316538 & 63.8 & 2.02 & 0 & .40 & 1.02 & 0 & 3.96 \\
\hline 05316550 & 8.60 & 2.88 & 0 & 2.36 & 0 & 0 & 4.03 \\
\hline 05316570 & 198 & 4.00 & 0 & 2.32 & 0 & .02 & 4.07 \\
\hline 05316690 & 3.47 & 7.87 & 0 & .16 & 0 & 1.00 & 4.74 \\
\hline 05316700 & 32.8 & 2.10 & 0 & 2.61 & 0 & .50 & 4.64 \\
\hline 05316800 & 1.58 & 26.1 & 0 & 2.59 & 0 & 0 & 3.74 \\
\hline 05316850 & .49 & 51.1 & 0 & 0 & 0 & 3.00 & 3.81 \\
\hline 05316900 & 3.18 & 47.7 & 0 & 1.82 & 0 & 0 & 4.58 \\
\hline 05316920 & .35 & 46.2 & 0 & 1.86 & 6.89 & .29 & 4.54 \\
\hline 05316950 & 777 & 5.85 & .52 & 3.37 & 1.84 & .49 & 4.20 \\
\hline 05317000 & 1,310 & 4.60 & .43 & 3.30 & 1.88 & .37 & 4.34 \\
\hline 05317200 & 169 & 6.77 & .25 & 3.09 & 8.47 & .92 & 5.01 \\
\hline 05317845 & 30.3 & 9.02 & 0 & .51 & 0 & 0 & 7.06 \\
\hline 05317850 & 2.17 & 24.8 & 0 & .08 & 2.91 & 0 & 7.10 \\
\hline 05318000 & 120 & 5.86 & 1.69 & 4.66 & .16 & 0 & 6.99 \\
\hline 05318100 & 9.39 & 6.84 & 0 & .27 & 0 & 0 & 6.67 \\
\hline
\end{tabular}


Table 2. Basin characteristics of streamflow-gaging stations used in this report.-Continued

$\left[\mathrm{mi}^{2}\right.$, square miles; $\mathrm{ft} / \mathrm{mi}$, feet per mile; in/yr, inches per year]

\begin{tabular}{|c|c|c|c|c|c|c|c|}
\hline $\begin{array}{l}\text { Station } \\
\text { number } \\
\text { (table 1) }\end{array}$ & $\begin{array}{c}\text { Drainage area } \\
\text { (DAREA) } \\
\left(\mathrm{mi}^{2}\right)\end{array}$ & $\begin{array}{c}\text { Main-channel } \\
\text { slope (SLOPE) } \\
\text { (ft/mi) }\end{array}$ & $\begin{array}{c}\text { Lake area } \\
\text { (LAKE) } \\
\text { (percent) }\end{array}$ & $\begin{array}{c}\text { Storage area } \\
\text { (STOR) } \\
\text { (percent) }\end{array}$ & $\begin{array}{c}\text { Soil hydro- } \\
\text { logic group A } \\
\text { (SOILA) } \\
\text { (percent) }\end{array}$ & $\begin{array}{c}\text { Soil hydro- } \\
\text { logic group } \\
\text { D (SOILD) } \\
\text { (percent) }\end{array}$ & $\begin{array}{c}\text { Generalized } \\
\text { mean annual } \\
\text { runoff }(R O F F) \\
(\mathrm{in} / \mathrm{yr})\end{array}$ \\
\hline 05318195 & 76.5 & 9.02 & 0.32 & 1.70 & 0.35 & 0 & 5.22 \\
\hline 05318300 & 13.0 & 14.7 & .54 & 3.37 & 3.67 & 0 & 4.71 \\
\hline 05318890 & 107 & 6.37 & 1.74 & 3.07 & .67 & 0 & 5.16 \\
\hline 05318897 & 107 & 6.30 & 1.73 & 3.05 & .66 & 0 & 5.17 \\
\hline 05319500 & 847 & 4.96 & 1.09 & 3.51 & 4.01 & .05 & 5.40 \\
\hline 05320200 & 1.31 & 17.8 & 0 & 11.6 & 0 & 11.7 & 6.12 \\
\hline 05320300 & 8.04 & 8.14 & 0 & 1.40 & 0 & 12.3 & 6.40 \\
\hline 05320400 & 5.77 & 10.4 & 0 & .34 & 0 & 47.5 & 6.42 \\
\hline 05320440 & 19.4 & 6.96 & 0 & .81 & 0 & .31 & 6.29 \\
\hline 05320480 & 339 & 2.46 & 1.53 & 3.53 & 0 & 12.3 & 6.54 \\
\hline 05320500 & 1,110 & 3.88 & 1.50 & 4.91 & .10 & 7.01 & 6.65 \\
\hline 05326100 & 67.5 & 3.53 & 0 & 1.27 & 0 & 0 & 4.78 \\
\hline 05327000 & 240 & 3.27 & 1.93 & 10.1 & .62 & .80 & 4.83 \\
\hline 05330150 & .22 & 64.2 & 0 & 0 & 0 & .61 & 5.97 \\
\hline 05330200 & 3.06 & 11.6 & 0 & 12.4 & 0 & 1.96 & 5.96 \\
\hline 05330300 & 62.9 & 2.33 & 4.21 & 17.3 & 0 & 3.16 & 5.88 \\
\hline 05330550 & 22.2 & 9.86 & .76 & 16.0 & 0 & 0 & 5.70 \\
\hline 05330600 & 2.67 & 13.8 & 0 & 12.7 & 0 & 0 & 5.55 \\
\hline 05335170 & 93.1 & 12.0 & .82 & 31.5 & 4.26 & 1.77 & 10.68 \\
\hline 05336200 & 26.4 & 9.39 & 0 & 43.4 & 5.44 & 4.41 & 10.74 \\
\hline 05336300 & 1.42 & 37.9 & 0 & 18.4 & 1.00 & 8.00 & 10.80 \\
\hline 05336550 & 6.16 & 6.61 & 0 & 18.2 & 2.90 & 6.83 & 9.97 \\
\hline 05336600 & .45 & 20.8 & 0 & 18.7 & 1.00 & 8.00 & 9.97 \\
\hline 05336700 & 870 & 5.26 & 1.63 & 35.6 & 12.5 & 4.40 & 10.50 \\
\hline 05337400 & 104 & 8.93 & 2.00 & 28.8 & 2.33 & .46 & 8.23 \\
\hline 05338200 & 3.28 & 19.0 & 0 & 24.0 & 0 & 0 & 9.25 \\
\hline 05338500 & 969 & 4.33 & 1.24 & 30.4 & 3.10 & 1.51 & 8.41 \\
\hline 05339747 & 43.9 & 3.61 & 5.49 & 34.0 & 7.27 & 4.38 & 7.63 \\
\hline 05340000 & 168 & 2.95 & 7.97 & 39.7 & 30.7 & .21 & 7.07 \\
\hline 05340050 & 240 & 2.41 & 10.3 & 38.5 & 23.4 & .40 & 7.22 \\
\hline 05345000 & 129 & 8.37 & .88 & 10.8 & 8.95 & .63 & 6.04 \\
\hline 05345900 & 38.4 & 5.90 & .09 & 2.51 & 17.7 & 0 & 6.26 \\
\hline 05348550 & 87.8 & 1.49 & 6.42 & 20.5 & 0 & 2.89 & 6.10 \\
\hline 05352700 & 1.03 & 29.0 & 0 & 1.76 & 0 & 1.31 & 7.15 \\
\hline 05352800 & 5.04 & 15.5 & 0 & .19 & 0 & 0 & 7.12 \\
\hline 05353800 & 436 & 3.59 & .59 & 3.93 & 0 & .90 & 6.97 \\
\hline 05355024 & 928 & 1.87 & 3.43 & 9.64 & .86 & 1.27 & 6.61 \\
\hline 05355100 & 2.22 & 51.5 & 0 & 2.58 & 0 & 0 & 6.58 \\
\hline 05355150 & 20.6 & 11.8 & 0 & .81 & 12.9 & 4.72 & 6.37 \\
\hline 05355200 & 1,340 & 3.24 & 2.55 & 8.11 & 2.24 & 1.19 & 6.54 \\
\hline 05355230 & .06 & 79.9 & 0 & 0 & 0 & 0 & 6.67 \\
\hline
\end{tabular}


Table 2. Basin characteristics of streamflow-gaging stations used in this report.-Continued

$\left[\mathrm{mi}^{2}\right.$, square miles; ft/mi, feet per mile; in/yr, inches per year]

\begin{tabular}{|c|c|c|c|c|c|c|c|}
\hline $\begin{array}{l}\text { Station } \\
\text { number } \\
\text { (table 1) }\end{array}$ & $\begin{array}{c}\text { Drainage area } \\
\text { (DAREA) } \\
\left(\mathrm{mi}^{2}\right)\end{array}$ & $\begin{array}{c}\text { Main-channel } \\
\text { slope (SLOPE) } \\
\text { (ft/mi) }\end{array}$ & $\begin{array}{c}\text { Lake area } \\
\text { (LAKE) } \\
\text { (percent) }\end{array}$ & $\begin{array}{c}\text { Storage area } \\
\text { (STOR) } \\
\text { (percent) }\end{array}$ & $\begin{array}{c}\text { Soil hydro- } \\
\text { logic group A } \\
\text { (SOILA) } \\
\text { (percent) }\end{array}$ & $\begin{array}{l}\text { Soil hydro- } \\
\text { logic group } \\
\text { D (SOILD) } \\
\text { (percent) }\end{array}$ & $\begin{array}{c}\text { Generalized } \\
\text { mean annual } \\
\text { runoff ( } R O F F) \\
(\mathrm{in} / \mathrm{yr})\end{array}$ \\
\hline 05372800 & 155 & 7.51 & 0.13 & 4.44 & 0 & 3.23 & 7.39 \\
\hline 05372930 & 78.4 & 19.6 & 0 & 3.68 & 2.97 & 19.1 & 7.53 \\
\hline 05372950 & 17.7 & 27.2 & 0 & 3.28 & .39 & 3.78 & 7.50 \\
\hline 05372990 & 38.2 & 14.7 & .09 & 1.91 & 0 & .01 & 7.36 \\
\hline 05372995 & 301 & 7.55 & .11 & 3.77 & 1.32 & 7.02 & 7.43 \\
\hline 05373080 & 21.8 & 5.46 & 0 & .60 & 0 & 0 & 7.06 \\
\hline 05373350 & .12 & 143 & 0 & 0 & 0 & 0 & 7.23 \\
\hline 05373700 & 10.0 & 18.2 & 0 & 2.13 & 0 & 0 & 6.81 \\
\hline 05373900 & .14 & 125 & 0 & 0 & 0 & 0 & 6.88 \\
\hline 05374000 & 1,150 & 5.71 & .25 & 2.70 & 1.13 & 2.63 & 7.15 \\
\hline 05374400 & 4.45 & 48.2 & 0 & .50 & 0 & 0 & 7.41 \\
\hline 05374900 & 1,420 & 5.02 & .20 & 2.77 & 1.20 & 2.13 & 7.18 \\
\hline 05376000 & 100 & 11.1 & 0 & 1.68 & .37 & 5.23 & 7.53 \\
\hline 05376110 & 39.1 & 19.2 & 0 & 1.83 & .37 & 2.77 & 7.66 \\
\hline 05376500 & 78.0 & 15.1 & 0 & 1.54 & 1.87 & 5.00 & 7.75 \\
\hline 05376800 & 271 & 11.8 & .02 & 2.14 & 2.17 & 3.96 & 7.65 \\
\hline 05377500 & 288 & 11.6 & .02 & 2.20 & 2.29 & 3.76 & 7.65 \\
\hline 05378235 & 45.0 & 25.0 & .06 & .60 & .08 & .39 & 7.96 \\
\hline 05378300 & 5.12 & 93.2 & 0 & .74 & .03 & .16 & 7.83 \\
\hline 05379000 & 9.08 & 88.5 & 0 & .41 & .16 & .79 & 8.02 \\
\hline 05383600 & .74 & 43.8 & 0 & 2.46 & 0 & 1.24 & 7.58 \\
\hline 05383700 & 2.41 & 58.0 & 0 & 2.15 & 0 & 14.6 & 7.65 \\
\hline 05383720 & 22.4 & 41.9 & 0 & 2.12 & 0 & 12.0 & 7.65 \\
\hline 05383850 & 14.1 & 13.8 & 0 & 2.80 & 0 & 0 & 7.62 \\
\hline 05384000 & 615 & 5.93 & .03 & 2.05 & .89 & .94 & 7.67 \\
\hline 05384100 & 3.85 & 63.8 & 0 & 1.18 & 3.78 & 1.42 & 8.02 \\
\hline 05384120 & 284 & 9.02 & .05 & 1.64 & 4.06 & .22 & 7.92 \\
\hline 05384150 & .08 & 229 & 0 & 0 & 0 & 0 & 7.98 \\
\hline 05384200 & 7.88 & 73.4 & 0 & .39 & 3.14 & .39 & 8.01 \\
\hline 05384300 & .13 & 58.3 & 0 & 0 & 0 & 0 & 7.89 \\
\hline 05384350 & 992 & 5.48 & .03 & 1.88 & 2.81 & .65 & 7.77 \\
\hline 05384400 & 28.3 & 15.6 & 0 & .60 & 1.00 & 2.02 & 7.87 \\
\hline 05384500 & 132 & 18.4 & 0 & .57 & 3.80 & .95 & 7.92 \\
\hline 05385000 & 1,250 & 5.26 & .03 & 1.73 & 3.38 & .69 & 7.82 \\
\hline 05385500 & 275 & 10.9 & 0 & .78 & .83 & .55 & 8.13 \\
\hline 05386000 & 1,540 & 5.20 & .02 & 1.57 & 3.02 & .65 & 7.88 \\
\hline 05387030 & 44.5 & 38.2 & .13 & .75 & .31 & .85 & 8.28 \\
\hline 05387490 & 20.8 & 24.8 & 0 & 1.26 & .23 & 2.09 & 8.46 \\
\hline 05387500 & 511 & 4.83 & .03 & 1.41 & .54 & 2.38 & 8.12 \\
\hline 05388000 & 568 & 4.64 & .03 & 1.34 & .52 & 2.71 & 8.16 \\
\hline 05388250 & 768 & 4.92 & .02 & 1.20 & .49 & 3.65 & 8.22 \\
\hline
\end{tabular}


Table 2. Basin characteristics of streamflow-gaging stations used in this report.-Continued

$\left[\mathrm{mi}^{2}\right.$, square miles; $\mathrm{ft} / \mathrm{mi}$, feet per mile; in/yr, inches per year]

\begin{tabular}{|c|c|c|c|c|c|c|c|}
\hline $\begin{array}{c}\text { Station } \\
\text { number } \\
\text { (table 1) }\end{array}$ & $\begin{array}{c}\text { Drainage area } \\
(D A R E A) \\
\left(\mathrm{mi}^{2}\right)\end{array}$ & $\begin{array}{c}\text { Main-channel } \\
\text { slope (SLOPE) } \\
(\mathrm{ft} / \mathrm{mi})\end{array}$ & $\begin{array}{c}\text { Lake area } \\
\text { (LAKE) } \\
\text { (percent) }\end{array}$ & $\begin{array}{c}\text { Storage area } \\
\text { (STOR) } \\
\text { (percent) }\end{array}$ & $\begin{array}{c}\text { Soil hydro- } \\
\text { logic group A } \\
\text { (SOILA) } \\
\text { (percent) }\end{array}$ & $\begin{array}{c}\text { Soil hydro- } \\
\text { logic group } \\
\text { D (SOILD) } \\
\text { (percent) }\end{array}$ & $\begin{array}{c}\text { Generalized } \\
\text { mean annual } \\
\text { runoff }(\text { ROFF }) \\
(\text { in/yr) }\end{array}$ \\
\hline 05457000 & 398 & 3.01 & 0.73 & 2.22 & 0 & 3.53 & 7.36 \\
\hline 05457080 & .97 & 33.7 & 0 & 2.64 & 0 & 0 & 7.57 \\
\hline 05457778 & 46.5 & 8.44 & 0 & 2.22 & 1.18 & .02 & 7.74 \\
\hline 05458960 & 29.2 & 5.61 & 0 & .51 & .08 & .79 & 7.19 \\
\hline 05474750 & 5.00 & 22.8 & 2.30 & 4.72 & 0 & 0 & 3.98 \\
\hline 05474760 & 2.10 & 33.7 & 0 & .46 & 0 & 0 & 4.01 \\
\hline 05474900 & 61.2 & 7.43 & 0 & .91 & 0 & 0 & 4.49 \\
\hline 05475400 & 3.34 & 26.8 & 0 & .29 & .20 & 0 & 4.85 \\
\hline 05475800 & 1.43 & 17.7 & 0 & 5.25 & 3.89 & 0 & 5.24 \\
\hline 05475900 & 5.14 & 20.2 & 0 & .31 & 5.00 & 0 & 5.17 \\
\hline 05476000 & 1,240 & 2.55 & 2.26 & 5.56 & .93 & .09 & 4.41 \\
\hline 05476010 & 6.25 & 43.8 & 0 & 1.26 & 5.00 & 0 & 5.30 \\
\hline 05476100 & 26.1 & 21.2 & 0 & .75 & 3.36 & 0 & 5.35 \\
\hline 05476900 & 15.5 & 13.8 & 0 & .19 & 0 & 0 & 5.53 \\
\hline 05476989 & 126 & 6.29 & .78 & 1.75 & .01 & 0 & 5.55 \\
\hline 06480400 & 61.3 & 10.1 & 0 & .96 & 1.21 & .90 & 2.97 \\
\hline 06480650 & 101 & 7.83 & 0 & 3.30 & .34 & .57 & 3.19 \\
\hline 06482500 & 31.0 & 11.9 & 0 & 2.14 & .16 & .83 & 3.40 \\
\hline 06482600 & 2.12 & 41.3 & 0 & .84 & 0 & 0 & 2.90 \\
\hline 06482610 & 482 & 4.08 & .03 & 1.91 & .03 & .42 & 3.10 \\
\hline 06482933 & 57.8 & 6.33 & 0 & 4.25 & .14 & 1.17 & 3.85 \\
\hline 06482950 & 2.47 & 19.4 & 0 & 4.88 & 0 & 0 & 3.45 \\
\hline 06482960 & .09 & 117 & 0 & .74 & 0 & 0 & 3.48 \\
\hline 06482970 & 48.2 & 7.81 & 0 & 2.73 & .49 & 0 & 3.90 \\
\hline 06483000 & 419 & 4.11 & .01 & 3.49 & .66 & .45 & 3.66 \\
\hline 06483050 & .21 & 75.3 & 0 & 0 & 0 & 0 & 3.61 \\
\hline 06483200 & 2.52 & 26.7 & 0 & 3.39 & 0 & 0 & 3.95 \\
\hline 06483210 & 2.15 & 29.2 & 0 & 3.45 & 0 & 0 & 4.09 \\
\hline 06483270 & 789 & 4.09 & .03 & 2.87 & .98 & .24 & 3.78 \\
\hline 06483350 & 39.5 & 7.18 & 0 & 1.68 & .35 & 0 & 4.40 \\
\hline 06483353 & 32.0 & 11.0 & 0 & .71 & .11 & 0 & 4.23 \\
\hline 06483410 & 13.9 & 4.80 & 0 & 2.31 & 0 & 0 & 4.52 \\
\hline 06483420 & 1.54 & 25.4 & 0 & 0 & 0 & 0 & 4.45 \\
\hline 06483430 & 33.2 & 6.68 & 0 & 1.02 & 0 & 0 & 4.50 \\
\hline 06483450 & 7.03 & 16.7 & 0 & .21 & 0 & 0 & 4.53 \\
\hline 06483460 & 88.7 & 6.15 & .11 & .67 & 0 & 0 & 4.59 \\
\hline 06483495 & 30.1 & 14.4 & 0 & .15 & 0 & 0 & 4.05 \\
\hline 06483500 & 1,580 & 4.04 & .02 & 1.82 & .59 & .12 & 3.95 \\
\hline 06603000 & 15.6 & 6.74 & 0 & 2.62 & 0 & 0 & 4.91 \\
\hline 06603500 & 7.65 & 4.47 & 0 & .08 & .53 & 0 & 5.03 \\
\hline 06603520 & 3.24 & 12.3 & 0 & .26 & 0 & 0 & 4.87 \\
\hline 06603530 & 41.1 & 6.73 & 0 & 1.26 & .10 & 0 & 4.93 \\
\hline
\end{tabular}


Table 3. Streamflow-gaging stations used to estimate generalized mean annual runoff.

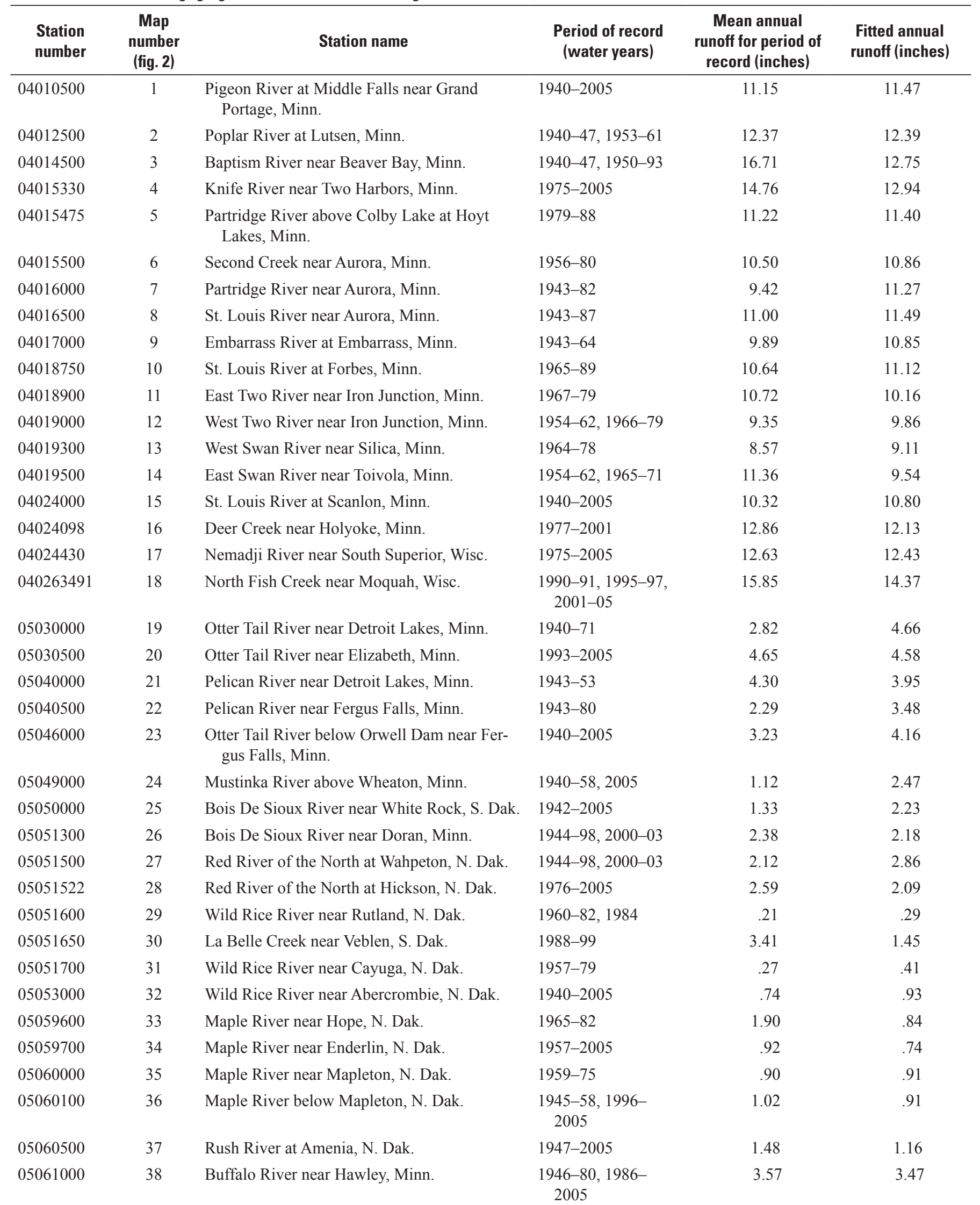


Table 3. Streamflow-gaging stations used to estimate generalized mean annual runoff.-Continued

\begin{tabular}{|c|c|c|c|c|c|}
\hline $\begin{array}{l}\text { Station } \\
\text { number }\end{array}$ & $\begin{array}{c}\text { Map } \\
\text { number } \\
\text { (fig. 2) }\end{array}$ & Station name & $\begin{array}{l}\text { Period of record } \\
\text { (water years) }\end{array}$ & $\begin{array}{l}\text { Mean annual } \\
\text { runoff for period of } \\
\text { record (inches) }\end{array}$ & $\begin{array}{l}\text { Fitted annual } \\
\text { runoff (inches) }\end{array}$ \\
\hline 05061500 & 39 & South Branch Buffalo River at Sabin, Minn. & 1946-80, 1986-2005 & 2.00 & 2.57 \\
\hline 05062000 & 40 & Buffalo River near Dilworth, Minn. & $1940-2005$ & 2.43 & 2.82 \\
\hline 05062500 & 41 & Wild Rice River at Twin Valley, Minn. & $1940-83,1990-2005$ & 3.41 & 3.96 \\
\hline 05064000 & 42 & Wild Rice River at Hendrum, Minn. & $1945-84,1986-2005$ & 2.96 & 3.39 \\
\hline 05064900 & 43 & Beaver Creek near Finley, N. Dak. & $1965-2003$ & .96 & .95 \\
\hline 05065500 & 44 & Goose River near Portland, N. Dak. & $1940-75,1981-82$ & .78 & 1.02 \\
\hline 05066500 & 45 & Goose River at Hillsboro, N. Dak. & $1940-2005$ & 1.21 & 1.08 \\
\hline 05067500 & 46 & Marsh River near Shelly, Minn. & $1945-83,1986-89$ & 3.90 & 2.41 \\
\hline 05068000 & 47 & Sand Hill River at Beltrami, Minn. & $1945-58$ & .21 & 3.18 \\
\hline 05069000 & 48 & Sand Hill River at Climax, Minn. & 1947-84, 1986-2005 & 2.80 & 2.81 \\
\hline 05074500 & 49 & Red Lake River near Red Lake, Minn. & $1940-94,2000-05$ & 3.65 & 5.20 \\
\hline 05075000 & 50 & $\begin{array}{l}\text { Red Lake River at High Landing near Goodridge, } \\
\text { Minn. }\end{array}$ & $1940-2000,2002-05$ & 3.88 & 5.01 \\
\hline 05076000 & 51 & Thief River near Thief River Falls, Minn. & $1940-81,1983-2005$ & 3.20 & 3.46 \\
\hline 05077700 & 52 & Ruffy Brook near Gonvick, Minn. & $1961-78$ & 4.06 & 4.50 \\
\hline 05078000 & 53 & Clearwater River at Plummer, Minn. & $1940-79,1983-2005$ & 4.37 & 4.11 \\
\hline 05078230 & 54 & Lost River at Oklee, Minn. & $1961-81,1983-2005$ & 4.00 & 3.88 \\
\hline 05078500 & 55 & Clearwater River at Red Lake Falls, Minn. & $1940-81,1983-2005$ & 3.60 & 3.75 \\
\hline 05082625 & 56 & $\begin{array}{l}\text { Turtle River at Turtle River State Park near Arvilla, } \\
\text { N. Dak. }\end{array}$ & 1993-2005 & 2.12 & 1.15 \\
\hline 05083000 & 57 & Turtle River at Manvel, N. Dak. & $1946-70$ & 1.13 & 1.37 \\
\hline 05084000 & 58 & Forest River near Fordville, N. Dak. & $1941-2005$ & 1.22 & 1.15 \\
\hline 05085000 & 59 & Forest River at Minto, N. Dak. & $1945-2005$ & .98 & 1.35 \\
\hline 05087500 & 60 & Middle River at Argyle, Minn. & 1951-81, 1983-2005 & 2.79 & 2.80 \\
\hline 05088000 & 61 & South Branch Park River near Park River, N. Dak. & $1940-50$ & 1.82 & 2.47 \\
\hline 05089000 & 62 & $\begin{array}{l}\text { South Branch Park River below Homme Dam, N. } \\
\text { Dak. }\end{array}$ & $1950-94$ & 1.50 & 1.40 \\
\hline 05089500 & 63 & Cart Creek at Mountain, N. Dak. & $1955-84$ & 2.24 & 1.69 \\
\hline 05090000 & 64 & Park River at Grafton, N. Dak. & $1940-2005$ & 1.36 & 1.49 \\
\hline 05092200 & 65 & Pembina County Drain 20 near Glasston, N. Dak. & $1972-82$ & .39 & 2.11 \\
\hline 05094000 & 66 & South Branch Two Rivers at Lake Bronson, Minn. & $\begin{array}{l}1942-43,1946-47 \\
1954-81,1986- \\
2005\end{array}$ & 3.86 & 3.18 \\
\hline 05095500 & 67 & Two Rivers below Hallock, Minn. & $1946-55$ & 2.16 & 3.16 \\
\hline 05096000 & 68 & North Branch Two Rivers near Lancaster, Minn. & $1942-55$ & 5.50 & 3.23 \\
\hline 05096500 & 69 & State Ditch \#85 near Lancaster, Minn. & $1943-55$ & 3.65 & 3.83 \\
\hline 05099600 & 70 & Pembina River at Walhalla, N. Dak. & $\begin{array}{l}\text { 1940-90, 1994-95, } \\
\text { 2001-05 }\end{array}$ & 1.02 & 1.34 \\
\hline 05100000 & 71 & Pembina River at Neche, N. Dak. & $1940-2005$ & 1.13 & 1.36 \\
\hline 05100500 & 72 & Herzog Creek near Concrete, N. Dak. & $1955-77$ & 2.23 & 1.75 \\
\hline 05101000 & 73 & Tongue River at Akra, N. Dak. & $1952-82$ & 1.81 & 1.68 \\
\hline 05101500 & 74 & Tongue River at Cavalier, N. Dak. & $1940-51$ & 1.86 & 1.68 \\
\hline 05106000 & 75 & Sprague Creek near Sprague, Manitoba, Canada & $1941-81,2000-05$ & 4.97 & 4.87 \\
\hline 05107000 & 76 & Pine Creek near Pine Creek, Minn. & $1940-53$ & 5.61 & 4.47 \\
\hline 05107500 & 77 & Roseau River at Ross, Minn. & 1940-91, 1996-2005 & 4.01 & 4.18 \\
\hline
\end{tabular}


Table 3. Streamflow-gaging stations used to estimate generalized mean annual runoff._-Continued

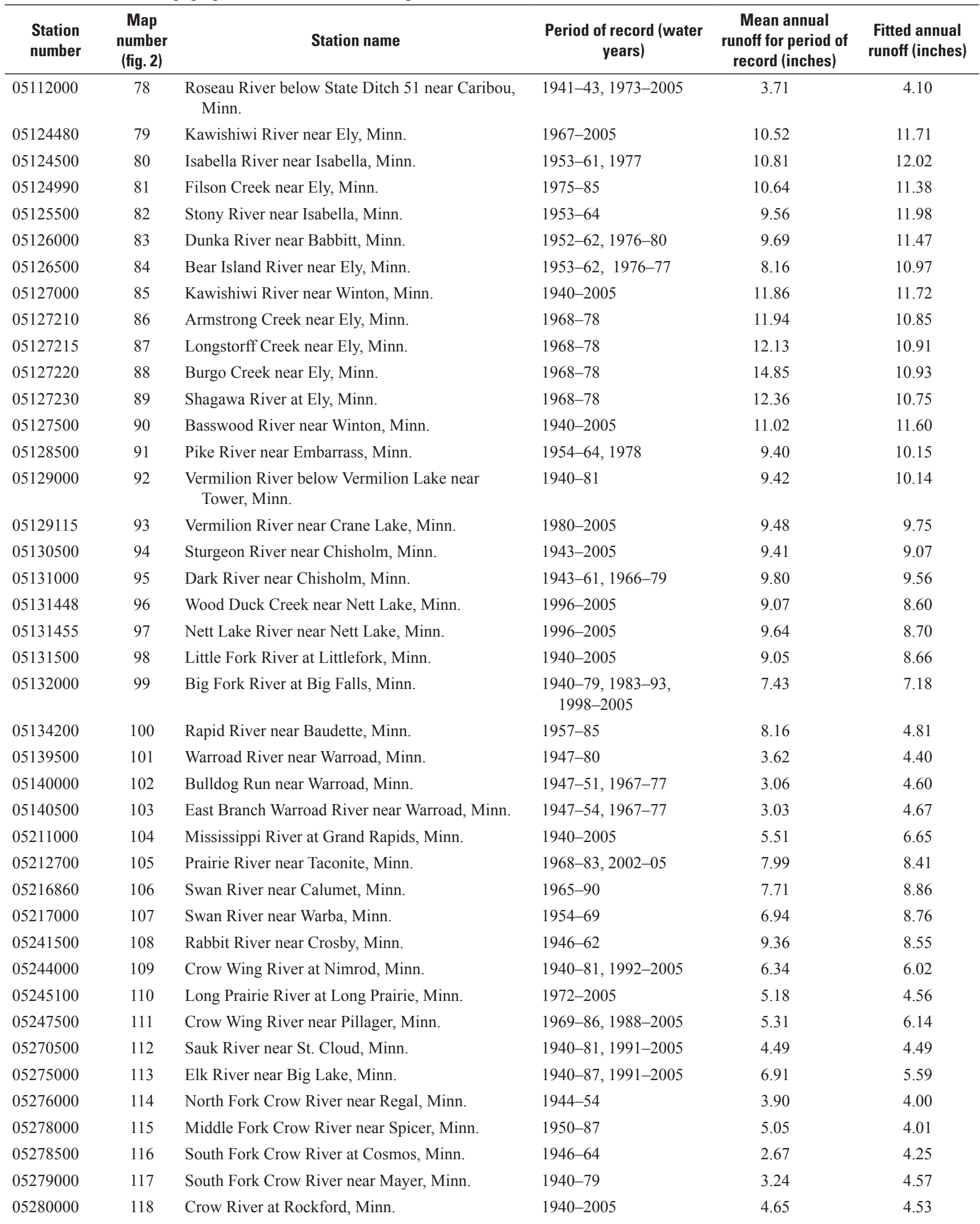


Table 3. Streamflow-gaging stations used to estimate generalized mean annual runoff._-Continued

\begin{tabular}{|c|c|c|c|c|c|}
\hline $\begin{array}{l}\text { Station } \\
\text { number }\end{array}$ & $\begin{array}{c}\text { Map } \\
\text { number } \\
\text { (fig. 2) }\end{array}$ & Station name & $\begin{array}{l}\text { Period of record (water } \\
\text { years) }\end{array}$ & $\begin{array}{c}\text { Mean annual } \\
\text { runoff for period } \\
\text { of record (inches) }\end{array}$ & $\begin{array}{l}\text { Fitted annual } \\
\text { runoff (inches) }\end{array}$ \\
\hline 05286000 & 119 & Rum River near St. Francis, Minn. & 1940-2005 & 6.77 & 7.14 \\
\hline 05287890 & 120 & Elm Creek near Champlin, Minn. & 1979-2005 & 6.17 & 5.64 \\
\hline 05289500 & 121 & Minnehaha Creek at Minnetonka Mills, Minn. & $1954-64$ & 1.33 & 5.46 \\
\hline 05290000 & 122 & Little Minnesota River near Peever, S. Dak. & $1940-81,1990-2002$ & 1.62 & 1.18 \\
\hline 05291000 & 123 & Whetstone River near Big Stone City, S. Dak. & 1940-2005 & 2.18 & 1.67 \\
\hline 05292000 & 124 & Minnesota River at Ortonville, Minn. & 1940-2005 & 1.54 & 1.51 \\
\hline 05292500 & 125 & Minnesota River near Odessa, Minn. & $1945-62$ & 1.30 & 1.60 \\
\hline 05292704 & 126 & North Fork Yellow Bank River near Odessa, Minn. & $1992-99,2001-02$ & 5.41 & 2.08 \\
\hline 05293000 & 127 & Yellow Bank River near Odessa, Minn. & $1940-99,2002-2005$ & 2.05 & 2.24 \\
\hline 05294000 & 128 & Pomme de Terre River at Appleton, Minn. & 1940-99, 2004-2005 & 2.07 & 2.94 \\
\hline 05300000 & 129 & Lac Qui Parle River near Lac Qui Parle, Minn. & 1940-99, 2002-2005 & 2.43 & 2.87 \\
\hline 05301000 & 130 & Minnesota River near Lac Qui Parle, Minn. & 1943-94, 1999-2005 & 2.80 & 2.34 \\
\hline 05304500 & 131 & Chippewa River near Milan, Minn. & 1940-2005 & 2.82 & 3.32 \\
\hline 05311400 & 132 & $\begin{array}{l}\text { South Branch Yellow Medicine River at Minneota, } \\
\text { Minn. }\end{array}$ & $1961-81,1983-87$ & 3.36 & 3.37 \\
\hline 05313500 & 133 & Yellow Medicine River near Granite Falls, Minn. & 1940-2005 & 2.98 & 3.46 \\
\hline 05315000 & 134 & Redwood River near Marshall, Minn. & $1941-2005$ & 3.64 & 3.53 \\
\hline 05316500 & 135 & Redwood River near Redwood Falls, Minn. & 1940-2005 & 3.49 & 3.82 \\
\hline 05317000 & 136 & Cottonwood River near New Ulm, Minn. & 1940-2005 & 4.18 & 4.57 \\
\hline 05317200 & 137 & Little Cottonwood River near Courtland, Minn. & 1974-2005 & 5.78 & 5.20 \\
\hline 05318000 & 138 & East Branch Blue Earth River near Bricelyn, Minn. & $1952-70$ & 4.23 & 6.99 \\
\hline 05319500 & 139 & Watonwan River near Garden City, Minn. & $1941-45,1977-2005$ & 6.23 & 5.50 \\
\hline 05320000 & 140 & Blue Earth River near Rapidan, Minn. & $1940-45,1950-2005$ & 6.01 & 6.02 \\
\hline 05320500 & 141 & Le Sueur River near Rapidan, Minn. & $1940-45,1950-2005$ & 6.72 & 6.70 \\
\hline 05327000 & 142 & High Island Creek near Henderson, Minn. & 1974-2005 & 5.87 & 4.82 \\
\hline 05332500 & 143 & Namekagon River near Trego, Wisc. & $1940-70,1988-2005$ & 13.80 & 12.99 \\
\hline 05333500 & 144 & St. Croix River near Danbury, Wisc. & 1940-81, 1985-2005 & 11.90 & 13.11 \\
\hline 05336000 & 145 & St. Croix River near Grantsburg, Wisc. & $1940-70$ & 12.05 & 9.96 \\
\hline 05336200 & 146 & Glaisby Brook near Kettle River, Minn. & $1960-70$ & 10.07 & 11.18 \\
\hline 05336700 & 147 & Kettle River below Sandstone, Minn. & 1968-2005 & 11.06 & 11.08 \\
\hline 05337400 & 148 & Knife River near Mora, Minn. & 1975-2001 & 8.18 & 8.51 \\
\hline 05338500 & 149 & Snake River near Pine City, Minn. & $1952-81,1992-2005$ & 8.58 & 8.68 \\
\hline 05340000 & 150 & Sunrise River near Stacy, Minn. & $1950-64$ & 5.17 & 7.13 \\
\hline 05340050 & 151 & Sunrise River near Lindstrom, Minn. & $1966-85$ & 5.96 & 7.18 \\
\hline 05341500 & 152 & Apple River near Somerset, Wisc. & $1940-70,1987-2005$ & 8.36 & 8.66 \\
\hline 05345000 & 153 & Vermillion River near Empire, Minn. & $1943,1974-2005$ & 7.39 & 6.02 \\
\hline 05353800 & 154 & Straight River near Faribault, Minn. & 1966-2005 & 8.98 & 7.00 \\
\hline 05355200 & 155 & Cannon River at Welch, Minn. & $1940-71,1992-2005$ & 7.02 & 6.62 \\
\hline 05356000 & 156 & $\begin{array}{l}\text { Chippewa River at Bishops Bridge near Winter, } \\
\text { Wisc. }\end{array}$ & 1940-2005 & 12.78 & 13.61 \\
\hline 05356500 & 157 & Chippewa River near Bruce, Wisc. & 1940-2005 & 12.72 & 12.80 \\
\hline 05360500 & 158 & Flambeau River near Bruce, Wisc. & $1952-2005$ & 13.13 & 13.22 \\
\hline 05364000 & 159 & Yellow River at Cadott, Wisc. & $1943-61$ & 10.18 & 11.05 \\
\hline 05365000 & 160 & Duncan Creek at Chippewa Falls, Wisc. & $1943-55$ & 10.07 & 9.60 \\
\hline 05366500 & 161 & Eau Claire River near Fall Creek, Wisc. & $1943-55$ & 9.67 & 9.78 \\
\hline
\end{tabular}


Table 3. Streamflow-gaging stations used to estimate generalized mean annual runoff._-Continued

\begin{tabular}{|c|c|c|c|c|c|}
\hline $\begin{array}{l}\text { Station } \\
\text { number }\end{array}$ & $\begin{array}{c}\text { Map } \\
\text { number } \\
\text { (fig. 2) }\end{array}$ & Station name & $\begin{array}{l}\text { Period of record (water } \\
\text { years) }\end{array}$ & $\begin{array}{c}\text { Mean annual } \\
\text { runoff for period } \\
\text { of record (inches) }\end{array}$ & $\begin{array}{l}\text { Fitted annual } \\
\text { runoff (inches) }\end{array}$ \\
\hline 053674464 & 162 & Yellow River at Barron, Wisc. & $1992-2005$ & 10.59 & 10.12 \\
\hline 05367500 & 163 & Red Cedar River near Colfax, Wisc. & $1940-61,1990$ & 9.67 & 10.44 \\
\hline 05368000 & 164 & Hay River at Wheeler, Wisc. & $1951-2005$ & 10.53 & 8.93 \\
\hline 05369000 & 165 & Red Cedar River at Menomonie, Wisc. & $1940-2005$ & 10.59 & 9.82 \\
\hline 05369945 & 166 & $\begin{array}{l}\text { Eau Galle River at Low-Water Bridge at Spring } \\
\text { Valley, Wisc. }\end{array}$ & $1983,1987-95$ & 8.18 & 7.77 \\
\hline 05370000 & 167 & Eau Galle River at Spring Valley, Wisc. & $1969-2005$ & 7.47 & 7.74 \\
\hline 05370500 & 168 & Eau Galle River at Elmwood, Wisc. & $1943-53$ & 6.40 & 7.68 \\
\hline 05372000 & 169 & Buffalo River near Tell, Wisc. & $1940-51$ & 8.37 & 8.31 \\
\hline 05372995 & 170 & South Fork Zumbro River at Rochester, Minn. & $1982-2005$ & 8.47 & 7.43 \\
\hline 05373000 & 171 & South Fork Zumbro River near Rochester, Minn. & $1953-81$ & 6.84 & 7.43 \\
\hline 05374000 & 172 & Zumbro River at Zumbro Falls, Minn. & $1940-80,2003,2005$ & 6.58 & 7.17 \\
\hline 05374500 & 173 & Zumbro River at Theilman, Minn. & $1940-56$ & 6.36 & 7.17 \\
\hline 05374900 & 174 & Zumbro River at Kellogg, Minn. & $1976-90$ & 8.53 & 7.17 \\
\hline 05376000 & 175 & North Fork Whitewater River near Elba, Minn. & $1940-41,1968-93$ & 6.61 & 7.53 \\
\hline 05376500 & 176 & South Fork Whitewater River near Altura, Minn. & $1940-71$ & 4.87 & 7.77 \\
\hline 05376800 & 177 & Whitewater River near Beaver, Minn. & $1976-85,1994-99$ & 8.64 & 7.66 \\
\hline 05377500 & 178 & Whitewater River at Beaver, Minn. & $1940-56$ & 6.26 & 7.66 \\
\hline 05378300 & 179 & Straight Valley Creek near Rollingstone, Minn. & $1971-85$ & 6.20 & 7.89 \\
\hline 05379000 & 180 & Gilmore Creek at Winona, Minn. & $1940-62$ & 5.57 & 8.02 \\
\hline 05379400 & 181 & Trempealeau River at Arcadia, Wisc. & $1961-77,2002-04$ & 9.71 & 8.27 \\
\hline 05379500 & 182 & Trempealeau River at Dodge, Wisc. & $1940-2005$ & 9.74 & 8.47 \\
\hline 05382000 & 183 & Black River near Galesville, Wisc. & $1940-2005$ & 11.62 & 9.76 \\
\hline 05383000 & 184 & La Crosse River near West Salem, Wisc. & $1940-70$ & 9.46 & 8.79 \\
\hline 05384000 & 185 & Root River near Lanesboro, Minn. & $1941-85,1987-90$ & 7.82 & 7.66 \\
\hline 05384500 & 186 & Rush Creek near Rushford, Minn. & $1943-79$ & 5.66 & 7.94 \\
\hline 05385000 & 187 & Root River near Houston, Minn. & $\begin{array}{l}1940-83,1991-2000 \\
2005\end{array}$ & 8.46 & 7.80 \\
\hline 05385500 & 188 & South Fork Root River near Houston, Minn. & $1954-83$ & 7.02 & 8.13 \\
\hline 05386000 & 189 & Root River below South Fork near Houston, Minn. & $1940-61$ & 7.02 & 7.90 \\
\hline 05387500 & 190 & Upper Iowa River at Decorah, Iowa & $1952-83,2003-05$ & 8.74 & 8.13 \\
\hline 05388000 & 191 & Upper Iowa River near Decorah, Iowa & $1940-51$ & 9.25 & 8.17 \\
\hline 05388250 & 192 & Upper Iowa River near Dorchester, Iowa & $1976-2005$ & 10.79 & 8.23 \\
\hline 05388500 & 193 & Paint Creek at Waterville, Iowa & $1953-73$ & 5.03 & 8.54 \\
\hline 05389000 & 194 & Yellow River at Ion, Iowa & $1940-51,2005$ & 9.28 & 8.61 \\
\hline 05389400 & 195 & Bloody Run Creek near Marquette, Iowa & $1992-2005$ & 8.91 & 8.71 \\
\hline 05411400 & 196 & Sny Magill Creek near Clayton, Iowa & $1992-2001$ & 10.32 & 8.76 \\
\hline 05411600 & 197 & Turkey River at Spillville, Iowa & $1957-73,1978-91$ & 9.40 & 8.33 \\
\hline 05412060 & 198 & Silver Creek near Luana, Iowa & $1987-98$ & 9.84 & 8.72 \\
\hline 05412100 & 199 & Roberts Creek above St. Olaf, Iowa & $1987-2001$ & 5.31 & 8.74 \\
\hline 05412500 & 200 & Turkey River at Garber, Iowa & $1940-2005$ & 9.32 & 8.78 \\
\hline 05414500 & 201 & Little Maquoketa River near Durango, Iowa & $1940-81$ & 8.99 & 9.05 \\
\hline 05420560 & 202 & Wapsipinicon River near Elma, Iowa & 1959-92 & 9.44 & 8.04 \\
\hline 05448500 & 203 & West Branch Iowa River near Klemme, Iowa & $1949-58$ & 4.62 & 7.48 \\
\hline 05449000 & 204 & East Branch Iowa River near Klemme, Iowa & $1949-76,1978-95$ & 7.40 & 7.70 \\
\hline
\end{tabular}


Table 3. Streamflow-gaging stations used to estimate generalized mean annual runoff.-Continued

\begin{tabular}{|c|c|c|c|c|c|}
\hline $\begin{array}{l}\text { Station } \\
\text { number }\end{array}$ & $\begin{array}{c}\text { Map } \\
\text { number } \\
\text { (fig. 2) }\end{array}$ & Station name & $\begin{array}{c}\text { Period of record (water } \\
\text { years) }\end{array}$ & $\begin{array}{l}\text { Mean annual } \\
\text { runoff for period } \\
\text { of record (inches) }\end{array}$ & $\begin{array}{l}\text { Fitted annual } \\
\text { runoff (inches) }\end{array}$ \\
\hline 05449500 & 205 & Iowa River near Rowan, Iowa & $1941-76,1978-2005$ & 7.91 & 7.80 \\
\hline 05457000 & 206 & Cedar River near Austin, Minn. & $1945-2005$ & 8.57 & 7.35 \\
\hline 05457700 & 207 & Cedar River at Charles City, Iowa & $\begin{array}{l}\text { 1965-95, 1997, } \\
\text { 2001-05 }\end{array}$ & 9.82 & 7.65 \\
\hline 05458000 & 208 & Little Cedar River near Ionia, Iowa & $1955-2005$ & 8.35 & 8.06 \\
\hline 05458500 & 209 & Cedar River at Janesville, Iowa & $1940-42,1946-2005$ & 8.60 & 7.92 \\
\hline 05458900 & 210 & West Fork Cedar River at Finchford, Iowa & $1946-2005$ & 9.00 & 8.59 \\
\hline 05459000 & 211 & Shell Rock River near Northwood, Iowa & $1946-86$ & 7.31 & 7.33 \\
\hline 05459500 & 212 & Winnebago River at Mason City, Iowa & $1940-2005$ & 7.88 & 7.43 \\
\hline 05460500 & 213 & Shell Rock River at Marble Rock, Iowa & $1943-53$ & 7.24 & 7.58 \\
\hline 05462000 & 214 & Shell Rock River at Shell Rock, Iowa & 1954-2005 & 8.49 & 7.86 \\
\hline 05463000 & 215 & Beaver Creek at New Hartford, Iowa & $1946-2005$ & 8.75 & 9.18 \\
\hline 05476000 & 216 & Des Moines River at Jackson, Minn. & $1940-2005$ & 4.88 & 4.44 \\
\hline 05476500 & 217 & Des Moines River at Estherville, Iowa & $1952-94$ & 4.38 & 4.52 \\
\hline 05476750 & 218 & Des Moines River at Humboldt, Iowa & $1965-2005$ & 6.43 & 5.37 \\
\hline 05478000 & 219 & East Fork Des Moines River near Burt, Iowa & $1952-74$ & 4.22 & 6.04 \\
\hline 05479000 & 220 & East Fork Des Moines River at Dakota City, Iowa & $1941-2005$ & 6.86 & 6.68 \\
\hline 05480000 & 221 & Lizard Creek near Clare, Iowa & $1941-81$ & 5.09 & 7.36 \\
\hline 05480500 & 222 & Des Moines River at Fort Dodge, Iowa & $1947-2005$ & 6.07 & 5.94 \\
\hline 05482135 & 223 & North Raccoon River near Newell, Iowa & $1983-95$ & 10.83 & 6.72 \\
\hline 05482170 & 224 & Big Cedar Creek near Varina, Iowa & 1960-91 & 7.30 & 6.94 \\
\hline 06478052 & 225 & Enemy Creek near Mitchell, S. Dak. & $1976-80,1982-87$ & 1.66 & .61 \\
\hline 06478390 & 226 & Wolf Creek near Clayton, S. Dak. & $1976-88$ & 1.38 & 1.26 \\
\hline 06478540 & 227 & Little Vermillion R near Salem, S. Dak. & $1967-2005$ & 1.31 & 1.57 \\
\hline 06478600 & 228 & East Fork Vermillion River near Parker, S. Dak. & $1996-2005$ & 1.58 & 2.10 \\
\hline 06478690 & 229 & West Fork Vermillion River near Parker, S. Dak. & $1962-2005$ & 1.53 & 1.95 \\
\hline 06479000 & 230 & Vermillion River near Wakonda, S. Dak. & $1946-83$ & 1.01 & 2.56 \\
\hline 06479010 & 231 & Vermillion River near Vermillion, S. Dak. & $1984-2005$ & 2.20 & 2.75 \\
\hline 06479215 & 232 & Big Sioux River near Florence, S. Dak. & $1985-2005$ & .31 & 1.24 \\
\hline 06479438 & 233 & Big Sioux River near Watertown, S. Dak. & $1973-2005$ & .56 & 1.48 \\
\hline 06479500 & 234 & Big Sioux River at Watertown, S. Dak. & $1946-72,2000-05$ & .39 & 1.57 \\
\hline 06479515 & 235 & Willow Creek near Watertown, S. Dak. & $1972-86$ & 2.32 & 1.74 \\
\hline 06479520 & 236 & Big Sioux River below Watertown, S. Dak. & $1995-2005$ & .89 & 1.79 \\
\hline 06479525 & 237 & Big Sioux River near Castlewood, S. Dak. & $1977-2005$ & .66 & 1.84 \\
\hline 06479529 & 238 & Stray Horse Creek near Castlewood, S. Dak. & $1969-85$ & 2.21 & 1.98 \\
\hline 06479640 & 239 & Hidewood Creek near Estelline, S. Dak. & $1969-85$ & 2.14 & 2.12 \\
\hline 06479910 & 240 & Sixmile Creek near Brookings, S. Dak. & $1971-80$ & 1.85 & 2.49 \\
\hline 06479980 & 241 & Medary Creek near Brookings, S. Dak. & $1981-90$ & 3.82 & 2.50 \\
\hline 06480000 & 242 & Big Sioux River near Brookings, S. Dak. & $1954-2005$ & 1.06 & 2.53 \\
\hline 06480400 & 243 & Spring Creek near Flandreau, S. Dak. & $1983-93$ & 4.52 & 2.81 \\
\hline 06480650 & 244 & Flandreau Creek above Flandreau, S. Dak. & $1982-91$ & 4.74 & 2.99 \\
\hline 06481000 & 245 & Big Sioux River near Dell Rapids, S. Dak. & $1949-2005$ & 1.28 & 2.60 \\
\hline 06481500 & 246 & Skunk Creek at Sioux Falls, S. Dak. & 1949-2001, 2004-05 & 2.02 & 2.63 \\
\hline 06482610 & 247 & Split Rock Creek at Corson, S. Dak. & $1966-89,2002-05$ & 2.90 & 2.99 \\
\hline
\end{tabular}




\section{Techniques for Estimating the Magnitude and Frequency of Peak Flows on Small Streams in Minnesota}

Table 3. Streamflow-gaging stations used to estimate generalized mean annual runoff.-Continued

\begin{tabular}{|c|c|c|c|c|c|}
\hline $\begin{array}{l}\text { Station } \\
\text { number }\end{array}$ & $\begin{array}{c}\text { Map } \\
\text { number } \\
\text { (fig. 2) }\end{array}$ & Station name & $\begin{array}{c}\text { Period of record (water } \\
\text { years) }\end{array}$ & $\begin{array}{l}\text { Mean annual } \\
\text { runoff for period } \\
\text { of record (inches) }\end{array}$ & $\begin{array}{l}\text { Fitted annual } \\
\text { runoff (inches) }\end{array}$ \\
\hline 06483000 & 248 & Rock River at Luverne, Minn. & $1996-97$ & 5.49 & 3.65 \\
\hline 06483270 & 249 & Rock River at Rock Rapids, Iowa & $1960-74$ & 2.82 & 3.76 \\
\hline 06483500 & 250 & Rock River near Rock Valley, Iowa & $1949-2005$ & 4.30 & 3.94 \\
\hline 06484000 & 251 & Dry Creek at Hawarden, Iowa & $1949-69$ & 2.26 & 3.79 \\
\hline 06600000 & 253 & Perry Creek at 38th Street, Sioux City, Iowa & $1946-69,1982-2004$ & 3.94 & 4.21 \\
\hline 06600100 & 254 & Floyd River at Alton, Iowa & $1956-2005$ & 4.18 & 4.72 \\
\hline 06600300 & 255 & West Branch Floyd River near Struble, Iowa & $1956-94$ & 3.86 & 4.25 \\
\hline 06600500 & 256 & Floyd River at James, Iowa & 1940-2005 & 3.97 & 4.56 \\
\hline 06605600 & 260 & Little Sioux River at Gillett Grove, Iowa & $1959-73$ & 3.86 & 5.29 \\
\hline 06605850 & 261 & Little Sioux River at Linn Grove, Iowa & 1973-2005 & 6.40 & 5.37 \\
\hline
\end{tabular}

\section{Publishing support provided by:}

Rolla Publishing Service Center

For additional information concerning this publication, contact:

Director, USGS Minnesota Water Science Center

2280 Woodale Drive, Mounds View, MN (763) 783-3100

Or visit the Minnesota Water Science Center Web Site at:

http://mn.water.usgs.gov 

